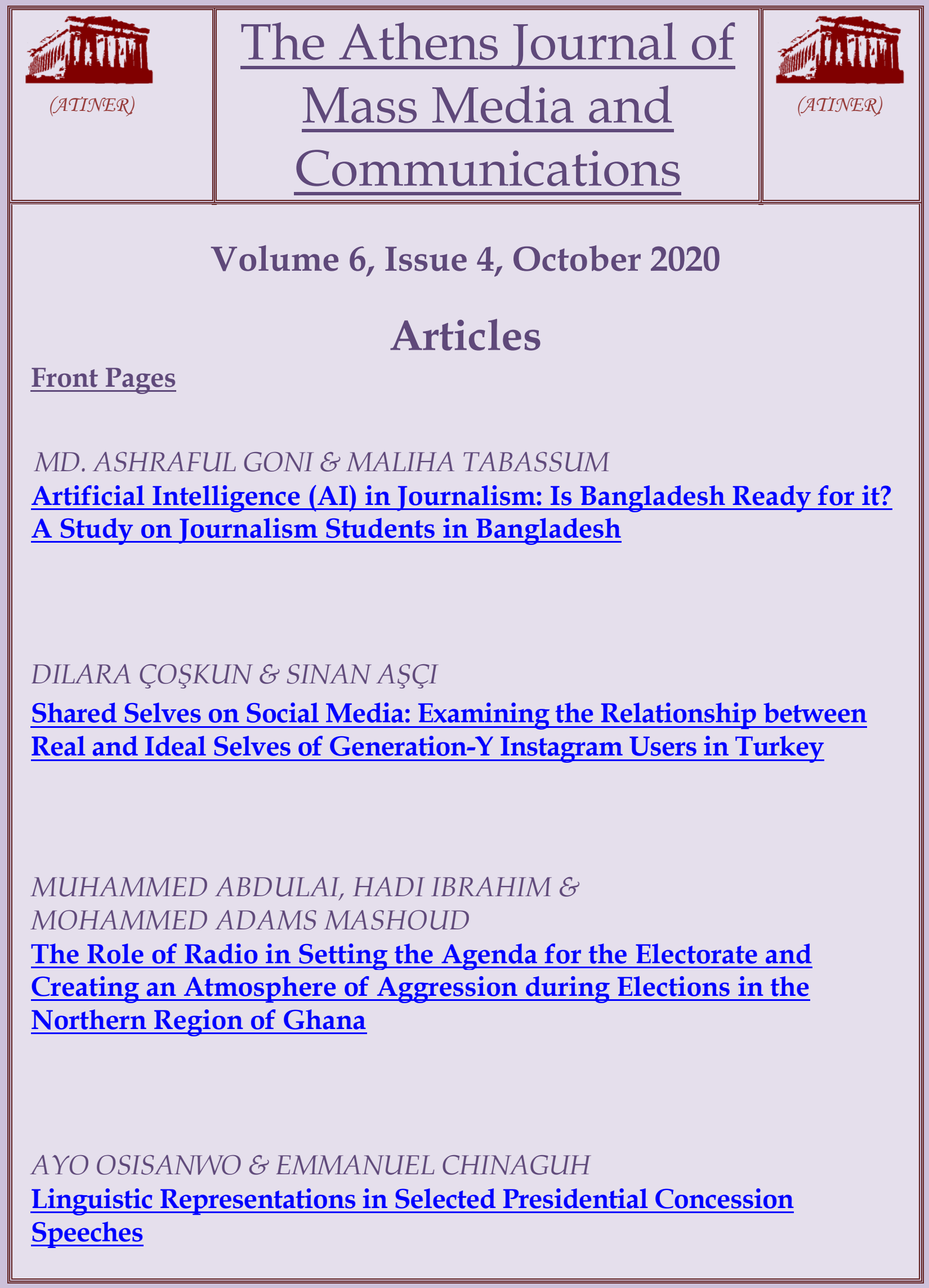




\section{Mission}

ATINER is an Athens-based World Association of Academics and Researchers based in Athens. ATINER is an independent and non-profit Association with a Mission to become a forum where Academics and Researchers from all over the world can meet in Athens, exchange ideas on their research and discuss future developments in their disciplines, as well as engage with professionals from other fields. Athens was chosen because of its long history of academic gatherings, which go back thousands of years to Plato's Academy and Aristotle's Lyceum. Both these historic places are within walking distance from ATINER's downtown offices. Since antiquity, Athens was an open city. In the words of Pericles, Athens"... is open to the world, we never expel a foreigner from learning or seeing". ("Pericles' Funeral Oration", in Thucydides, The History of the Peloponnesian War). It is ATINER's mission to revive the glory of Ancient Athens by inviting the World Academic Community to the city, to learn from each other in an environment of freedom and respect for other people's opinions and beliefs. After all, the free expression of one's opinion formed the basis for the development of democracy, and Athens was its cradle. As it turned out, the Golden Age of Athens was in fact, the Golden Age of the Western Civilization. Education and (Re)searching for the 'truth' are the pillars of any free (democratic) society. This is the reason why Education and Research are the two core words in ATINER's name. 
The Athens Journal of Mass Media and

Communications

ISSN NUMBER: 2407-9677 - DOI: 10.30958/ajmmc

Volume 6, Issue 4, October 2020

Download the entire issue ( $\underline{\mathrm{PDF}})$

$\underline{\text { Front Pages }}$

i-viii

Artificial Intelligence (AI) in Journalism: Is

209

Bangladesh Ready for it? A Study on Journalism

Students in Bangladesh

Md. Ashraful Goni \& Maliha Tabassum

Shared Selves on Social Media: Examining the

Relationship between Real and Ideal Selves of

Generation-Y Instagram Users in Turkey

Dilara Çoşkun E Sinan Aşçı

The Role of Radio in Setting the Agenda for the

Electorate and Creating an Atmosphere of Aggression during Elections in the Northern Region of Ghana

Muhammed Abdulai, Hadi Ibrahim \&

Mohammed Adams Mashoud

Linguistic Representations in Selected Presidential

271

Concession Speeches

Ayo Osisanwo \& Emmanuel Chinaguh 


\section{The Athens Journal of Mass Media and Communications Editorial and Reviewers' Board}

$\underline{\text { Editors }}$

- Dr. John Pavlik, Head, Mass Media and Communication Unit, ATINER \& Professor, Journalism and Media Studies, School of Communication and Information, Rutgers University, USA.

- Dr. Yorgo Pasadeos, Director, Social Sciences Division, ATINER \& Professor Emeritus, University of Alabama USA.

- Dr. Patrick Vyncke, Professor of Communication Management, Department of Communication Sciences, Ghent University, Belgium.

\section{Editorial Board}

- Dr. John Pavlik, Head, Mass Media and Communication Unit, ATINER \& Professor, Rutgers University, USA.

- Dr. Burak Dogu, Academic Member, ATINER \& Vice Dean, Izmir University of Economics, Turkey.

- Dr. Andzela Armoniene, Head of The Fund Young Researcher, Lithuania.

- Dr. Mariam Gersamia, Professor \& Head, Division of Journalism and Mass Communication, Ivane Javakhishvili Tbilisi State University, Georgia.

- Dr. Egle Jaskuniene, Associate Professor \& Vice Dean for Research, Faculty of Creative Industries, Vilnius Gediminas Technical University, Lithuania.

- Dr. Berrin Yanikkaya, Academic Member, ATINER and Professor \& Head, School of Communication Studies, Auckland University of Technology, New Zealand.

- Dr. Dali Osepashvili, Professor, Department of Journalism and Mass Communication, Ivane Javakhishvili Tbilisi State University, Georgia.

- Dr. Walter Wymer, Academic Member, ATINER \& Professor of Marketing, University of Lethbridge, Canada.

- Dr. Alan Albarran, Academic Member, ATINER \& Professor, The University of North Texas, USA.

- Dr. Patricia L. Dooley, Elliott Distinguished Professor of Communication, Wichita State University, USA.

- Dr. Catherine Ann Collins, Professor, Department of Rhetoric, Willamette University, USA.

- Dr. Pamela Doyle Tran, Professor of Electronic News, University of Alabama, USA.

- Dr. S. Andrews, Professor, Department of Information Technology, Mahendra Engineering College, India.

- Dr. Emmanuel Ngwainmbi, Department of Communication Studies, The University of North Carolina, USA.

- Dr. Zsolt Alfred Polgar, Academic Member, ATINER \& Associate Professor, 
Technical University of Cluj-Napoca, Romania.

- Dr. Margaret M. Cassidy, Academic Member, ATINER \& Associate Professor, Adelphi University, USA.

- Dr. Baris Coban, Associate Professor, Communication Sciences Department, Dogus University, Turkey.

- Dr. Ulas Basar Gezgin, Associate Professor of Applied Communication, British University Vietnam, Vietnam.

- Dr. Anya Luscombe, Associate Professor and Head, Department of Academic Core, University College Roosevelt, The Netherlands.

- Dr. Charles Obot, Academic Member, ATINER \& Associate Professor, University of Uyo, Nigeria.

- Dr. Ceren Sozeri, Associate Professor, Faculty of Communication, Galatasaray University, Turkey.

- Dr. Matthew D. Matsaganis, Assistant Professor, Department of Communication, State University of New York (SUNY), USA.

- Dr. Geneviève A. Bonin, Assistant Professor, University of Ottawa, Canada.

- Dr. Klarissa Lueg, Assistant Professor, Aarhus University, Denmark.

- Dr. George Pavlou, Assistant Professor, European University, Cyprus.

- Dr. Yolandi Slabbert, Senior Lecturer, Department of Communication Science, University of South Africa, South Africa.

- Dr. Daniel Binns, Academic Member, ATINER \& Lecturer, RMIT University, Australia.

- Dr. Binoy Kampmark, Lecturer in Social Sciences, School of Global, Urban and Social Studies, RMIT University, Australia.

- Dr. Sarah Sparke, Academic Member, ATINER \& Research Associate, CMIR, University of the West of England, UK.

- Dr. Vittoria Sacco, Postdoctoral Assistant, Neuchatel University, Switzerland.

- Ms. Mania Alehpour, PhD Candidate, University of Tehran, Iran.

- General Managing Editor of all ATINER's Publications: Ms. Afrodete Papanikou

- ICT Managing Editor of all ATINER's Publications: Mr. Kostas Spyropoulos

- Managing Editor of this Journal: Ms. Zoi Charalampous (bio)

\section{Reviewers' Board}

Click Here 


\section{President's Message}

All ATINER's publications including its e-journals are open access without any costs (submission, processing, publishing, open access paid by authors, open access paid by readers etc.) and is independent of presentations at any of the many small events (conferences, symposiums, forums, colloquiums, courses, roundtable discussions) organized by ATINER throughout the year and entail significant costs of participating. The intellectual property rights of the submitting papers remain with the author. Before you submit, please make sure your paper meets the basic academic standards, which includes proper English. Some articles will be selected from the numerous papers that have been presented at the various annual international academic conferences organized by the different divisions and units of the Athens Institute for Education and Research. The plethora of papers presented every year will enable the editorial board of each journal to select the best, and in so doing produce a top-quality academic journal. In addition to papers presented, ATINER will encourage the independent submission of papers to be evaluated for publication.

The current issue is the fourth of the sixth volume of the Athens Journal of Mass Media and Communications (AJMMC), published by the Mass Media \& Communication Unit of ATINER

Gregory T. Papanikos

President

ATINER 


\section{Athens Institute for Education and Research}

\section{A World Association of Academics and Researchers}

19th Annual International Conference on Communication and Mass Media, 10-13 May 2021, Athens, Greece

The Mass Media \& Communication Unit of ATINER organizes its 19th Annual International Conference on Communication and Mass Media, 10-13 May 2021, Athens, Greece sponsored by the Athens Journal of Mass Media and Communications. The aim of the conference is to bring together academics and researchers of Communications, Mass Media and other related disciplines. Please submit a proposal using the form available (https://www.atiner.gr/2021/FORM-MED.doc).

- Abstract Submission: 12 October 2020

- Acceptance of Abstract: 4 Weeks after Submission

- Submission of Paper: 12 April 2021

\section{Academic Members Responsible for the Conference}

- Dr. John Pavlik, Head, Mass Media and Communication Research Unit, ATINER \& Professor, Rutgers University, USA.

- Dr. Yorgo Pasadeos, Director, Social Sciences Division, ATINER \& Professor Emeritus, University of Alabama USA.

\section{Social and Educational Program}

The Social Program Emphasizes the Educational Aspect of the Academic Meetings of Atiner.

- Greek Night Entertainment (This is the official dinner of the conference)

- Athens Sightseeing: Old and New-An Educational Urban Walk

- Social Dinner

- Mycenae Visit

- Exploration of the Aegean Islands

- Delphi Visit

- Ancient Corinth and Cape Sounion

\section{Conference Fees}

Conference fees vary from $400 €$ to $2000 €$ Details can be found at: https://www.atiner.gr/2019fees 


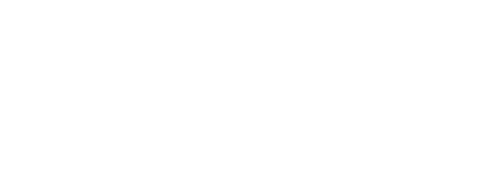




\title{
Artificial Intelligence (AI) in Journalism: Is Bangladesh Ready for it? A Study on Journalism Students in Bangladesh
}

\author{
By Md. Ashraful Goni* \& Maliha Tabassum ${ }^{ \pm}$
}

\begin{abstract}
While talking about technological development of the world, we always define the word "world" with developed nations or first world countries predicting that developing nations will catch up or follow the trend. This statement is also true for journalism as it is one of the world's fastest growing tech-based sectors. First world countries newsrooms are getting ready for the fourth major wave of journalism (after online, mobile and social media) to use large scale amount of data with the help of AI. In this circumstance, this study focuses on future journalists of Bangladesh; those who have enrolled themselves in this discipline in different universities to pursue a career in the field of journalism. A survey on undergraduate university students from different universities of Bangladesh helped us to predict the readiness of Bangladeshi future journalists for the new wave of digital journalism which will likely hit Bangladesh within the next three to four years. This study will help journalism practitioners and academicians to prepare for the new wave of digital journalism.
\end{abstract}

Keywords: Artificial Intelligence (AI), Bangladesh, digital journalism, fourth wave of journalism

\section{Introduction}

Today we are living in a digital world, in a society which is interconnected with unimaginable opportunities. In this digital world, journalism is a profession hugely dependent on technology. From gathering a piece of news to print/ broadcast, everywhere technology is a crying need. But the most interesting fact is that nowadays technologies are no longer used as a helping hand to journalism, rather they are re-shaping the way journalism is. Artificial intelligence is being used to make journalism more efficient than ever before. Big organizations like New York Times are using AI to speed up research, accumulating and crossreferring data (Underwood, 2019). Since 2016 Washington Post is using AI based robo-reporters which they claimed have written 850 news articles within one year (Moses, 2017). This term, Artificial Intelligence, has been popularized more as "Automated Journalism" where stories, videos, data are created on a large scale using artificial intelligence with minimal human input (Arkadium, 2019). So, it has been already half a decade since artificial intelligence is taking in account seriously by big giants of journalism sector.

\footnotetext{
*Lecturer, Department of Mass Communication and Journalism, Bangladesh University of Professionals, Bangladesh.

${ }^{ \pm}$Lecturer, Department of Mass Communication and Journalism, Bangladesh University of Professionals, Bangladesh.
} 
In this circumstance, Bangladesh is also experiencing the urge to accommodate $\mathrm{AI}$ in mainstream journalism. In Bangladesh, use of AI in journalism field is not sufficient enough. But, with the advancement of technology, AI will soon enter and will be indispensable in no time. Changes are happening; especially Bangladeshi Journalists are keen to know modern journalistic skills like digital and data journalism. One organization named "Dataful" is arranging special training programme for professionals and students of journalism (UNB, 2020).

Taking these changes in consideration, this study mainly focuses on the future journalists, the students of Journalism from different universities. So, this research is focused on their perception and knowledge of using AI in journalism to understand their mental readiness to welcome the bigger change.

\section{What is Artificial Intelligence?}

Artificial intelligence has got an abundance of definitions and explanations. But most people hardly have clear ideas on AI. In a report created by Data \& Society one interviewee said, "If I walked into a room and said, "We're going to talk about an artificial intelligent personal assistant, "nearly everyone would have a picture in their head. The problem is everybody's picture would be different" (Elish and Hwang, 2017). Especially in the journalism sector the definition is being shaped and reshaped every day.

Artificial intelligence is something that is not "natural". It works in contrast with typical ways humans and animals display their intelligence. Artificial intelligence shortly named as AI is based on intelligent agent, an autonomous entity working with sensors giving rational result by analyzing like a computer programme (Russell and Norvig, 2003). Some scholars are naming it as "Weak AI" as AI may outperform human in some specific task like facial recognition or playing cheese but not in specialized ones based on cognition (Lu et al. 2018).

In journalism, using AI has got specialized naming like "Automated Journalism" (Carlson, 2015; Weeks, 2014), "Algorithmic Journalism" (Napoli, 2014; Uricchio, 2011) or "Robot Journalism" (Clerwall, 2014). Whatever be the name, journalism has become more modern and trendier with the help of AI than ever before. AI has made news to be generated faster, with fewer errors. From processing big data to in depth investigation, AI is used everywhere by big news companies (Graefe, 2016). Some scholars are considering it as an opportunity for journalists to free from routine works and a suitable cost cutting tool (Dorr, 2016). On the other hand, some scholars are considering AI as a threat to journalism which will replace human journalists than helping them out (Montal and Reich, 2017). Whatever be the controversy, no one can deny the importance of AI in every profession especially in the field of journalism. Especially for a developing country like Bangladesh, usage of AI has become a crying need to keep pace with the modern era and modern journalistic arena. As AI will come into full force globally in no time, it is very important to teach the future journalists the possibilities, threats and challenges of AI and getting them prepared for the big wave. 


\section{Research Background}

As described earlier, AI has become indispensable in several sectors including journalism. For Bangladesh, it is quite a new phenomenon. So, accepting AI as a new technology is very challenging for journalists, perhaps more challenging for the new learners. There can always be a possible resistance for new technology as some scholars described it "to remain unaffected or undamaged by something" (O'Neill, 2001, p. 1050). Maurer (1997) conducted a survey on fortune 1000 companies on using a new software-based application by the employees and found that the reason for the failure of using the new software is resisting a new technology. He concluded the research with the suggestion that motivational strategies are best to create a sense of urgency among them to welcome new technologies. Following this, Sevier (2003) highlighted the fact that, these strategies should be implemented in the academia as well so that students can enter their professional life with a different mindset.

In accepting AI, there can be several challenges coming up. Biswal and Gouda (2020) stated that most people are resisting AI usage in journalism because of the lack of credibility. According to them, some academicians and practitioners firmly believe that human's credibility, creativity and humor cannot be replaced by AI. Some are concerned about the ethical issues; some are on losing their job to machines. These sorts of mental blockage are working against the use of mainstream news production, according to them.

For this reason, this study explores the use of AI in Bangladesh as a newly emerged sector and focusing more on the "Mental Readiness" of the future journalists rather than infrastructural challenges. How the undergraduate students perceive AI, how much they are using AI, what is the future of AI to them are some of the prime focuses of this study.

\section{Literature Review}

AI has always been in spotlight for many scholars, practitioners and academicians. Dorr (2016) termed AI in journalism as "Algorithmic Journalism" where structured data is converted into texts through Natural Language Generation (NLG). Although having some technological limitations, NLG has huge economic benefit where production cost is much less than a human journalist. In this research, thirteen semi structured interviews were conducted on relevant service providers on NLG.

The study was conducted in two phrases. In first phrase, technological potential analysis brought out the several limitations including infrastructural incapability of an algorithmic model. The second phrase uncovers the economic potential of NLG in near future such as arranging big data, generating news in multiple language and overall minimizing production cost in reaching broader audience.

Thurman et al. (2017) did a qualitative study where ten journalists were given advanced training on different AI software and were given space to work 
independently with a software enable to generate automated texts. The journalists then went through semi-structured interviews where their opinions were investigated qualitatively.

Although having great speed and time benefit, this study found AI technologies still in the early stages of development and therefore not "worthy of" making the whole journalism field automated. Journalists pointed out six major limitations including lack of human angles, lack of sensitivity, ethical dilemmas and of course problems in understanding news behind news. It is true that Journalists could point out the limitations because of their professional experiences but again this study also noticed their incapability in full use of AI software.

In the book "Tech Giants, Artificial Intelligence, and the Future of Journalism" (2019) writer Jason Whittaker talked about five biggest tech giants (Amazon, Apple, Facebook, Google and Microsoft) who are working intensively with artificial intelligence and thus creating impact in the future of journalism. According to him, these tech-giants are creating such a "Digital Ecosystem" where public sphere are emerging with the help of social machines and gaining social computational power.

He stated that artificial intelligence has changed the understanding of the consumers about journalism and media, so as people's behavior in consumption. The shift in automation especially by using artificial intelligence has compelled big tech-giants thinking more about these changing trends. It has placed media industry in a strong position where tech-giants have no other options than to invest in developing AI to make maximum profit out of it. He predicted an even better future of AI in journalism practice where AI will not only help in profit making but also will aid human in understanding and transforming the world.

Some scholars have given several valuable recommendations specially for learning AI in the academic field of journalism (Broussard et al., 2019). According to them the learning curve should follow a more conceptual path starting for what is and what not is AI. Clear understanding on AI will help to understand the strengths, weaknesses, ethical issues and applications of AI with the field of journalism.

According to them, understanding AI beyond the definition and overcoming the fear of technologies can be one of the major challenges journalism is facing currently. So, they recommended to include special courses in the academic arena with resourceful contents and specialized faculties.

Lewis et al. (2019) talked about human machine communication domain where the typical role of machines has changed, working as a news source rather than news channels. They termed this change as "Ontological Transaction" by focusing on the shift of technology use in traditional journalism practice.

Their research concluded by tagging AI as "Communicator" rather than a "Mediator" inside any given context. Automated texts, chatbots, social bots are reducing human roles and thus pushing the understanding of AI further. News writing software are challenging creative writings, thus questioning some fundamental principles of journalism practices. According to them, human machine communication domain is yet unclear to us. As our relationships with 
machines are changing so rapidly with newly emerged technologies and innovations, this relationship with devices are subject to ongoing negotiations.

\section{Theoretical Framework}

To analyze the readiness of Bangladesh in using AI in the field of journalism, Technology Acceptance Model (TAM) has been taken as the theoretical framework of this study. It is one of the widely used models introduced by Davis (1986) to understand how users are accepting newer technologies in their day to day life. The theoretical background of this model comes from Theory of Reasoned Action (Fishbein and Azjen, 1975) which states that attitude is influenced by beliefs, which changes the intention and thus generate new behavior in someone. The model constructed by Davis (1986) is shown in Figure 1.

Figure 1. Technology Acceptance Model (Adapted from Davis, 1986)

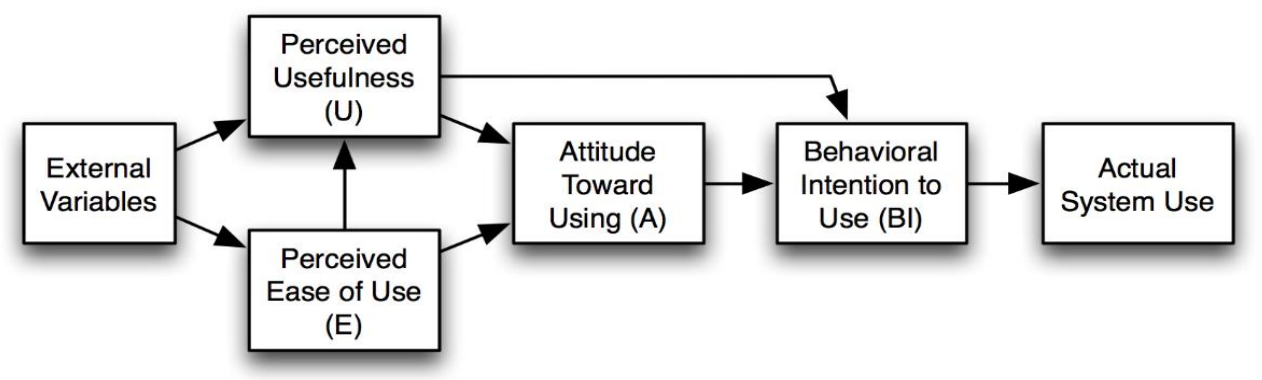

This model has got two important constructs "Perceived Usefulness" and "Perceived Ease of Use" which are actually individual attitudes and can be influenced by external behaviors. According to Davis (1986) these two constructs led to attitude and intentional changes and thus actually accepting the system usage. Taking about external variables, it varies from context to context. For example, in using mobile applications Kim (2012) got five external variables (Utility, Quality of Content, Entertainment, Price, Design) important where Shin (2016) got another five (Interaction, Information Offer, Personalization, Playfulness, Instant Connectivity) variables playing crucial roles in TAM.

Davis has done several experiments to validate his model alongside other scholars in this field. This model showcases the mutual relationships between external variables with two constructs "Perceived Usefulness" and "Perceived Ease of Use" and thus affecting the system use at the end. Davis found both these constructs related to two things- self-reported current usage and self-predicted future usage.

Although having got huge acceptance in academic and research arena, it was identified with one big limitation, the absence of social influence. Taking that in consideration, in 2000 Venkatesh and Davis (2000) introduced an extended version popularly known as TAM 2.1 the modified model of TAM 2 is shown in Figure 2. 
Figure 2. TAM 2 Model (Adapted from Venkatesh and Davis, 2000)

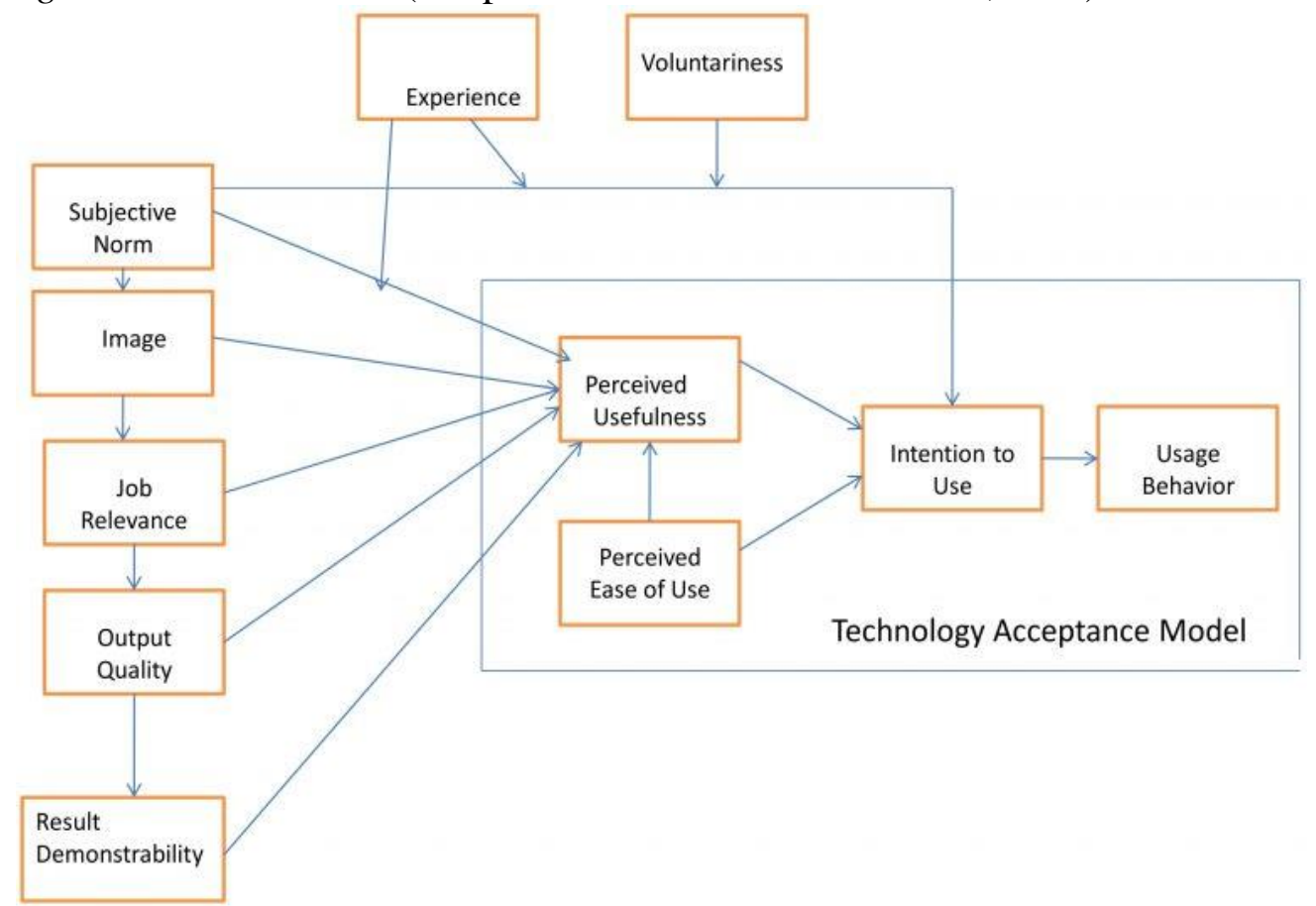

In TAM 2, external variables are easily understandable and identifiable. Here, attitude is excluded from the model and two specific external constructs (social influence process and the identical tool process) are included. Subjective norms, voluntariness, experiences and image are under the social influence process and job relevance, output quality, and result demonstrability are under identical tool process. Instrumental determinants are defined in Table 1.

Table 1. Definition of Variables by Scholars

\begin{tabular}{|c|c|c|}
\hline Process & Variables & Definition of Variable \\
\hline \multirow[t]{4}{*}{ Social Influence } & Subjective Norms & $\begin{array}{l}\text { It means if someone is important to him/her, he/she should not } \\
\text { put their behavior in question (Fishbein and Ajzen, 1975, p. } \\
302 \text { ) }\end{array}$ \\
\hline & Voluntariness & $\begin{array}{l}\text { It means someone who is a potential adopter will take the } \\
\text { decision by choice/ non-mandatorily (Venkatesh and Davis, } \\
2000 \text {, p. 188) }\end{array}$ \\
\hline & Image & $\begin{array}{l}\text { It can be described as the increase of someone's status by } \\
\text { using the innovation from a societal perspective (Moore and } \\
\text { Benbasat, 1991, p. 195) }\end{array}$ \\
\hline & Experience & $\begin{array}{l}\text { "The direct effect of subjective norm on intention may subside } \\
\text { over time with increased system experience" (Venkatesh and } \\
\text { Davis, 2000, p. 189) }\end{array}$ \\
\hline \multirow[t]{3}{*}{$\begin{array}{l}\text { Cognitive } \\
\text { Instrumental }\end{array}$} & Job Relevance & $\begin{array}{l}\text { Can be described as individual perception of using a new } \\
\text { innovation having relevance to someone's job where the } \\
\text { innovation is capable of carrying out set of tasks (Venkatesh } \\
\text { and Davis, 2000, p. 191) }\end{array}$ \\
\hline & Output Quality & $\begin{array}{l}\text { Individual perception on how well the innovation can perform } \\
\text { the tasks matching their job relevance (Davis et al., 1992, p. } \\
\text { 985) }\end{array}$ \\
\hline & $\begin{array}{c}\text { Result } \\
\text { Demonstrability }\end{array}$ & $\begin{array}{l}\text { "Tangibility of results of using the innovation which directly } \\
\text { influence perceived usefulness" (Moore and Benbasat, 1991, } \\
\text { p. 203) }\end{array}$ \\
\hline
\end{tabular}




\section{Research Hypothesis}

The main objective of this research is to find out the readiness of Bangladesh in using AI in the field of journalism. The following hypotheses have been developed by the researcher and tested in the study:

1. Some external variables of technology acceptance model have influence on student's system use.

2. Internal constructs are also working with external ones to accelerate system usage behaviors.

3. Being comparatively new concept in Bangladesh, students have negative intentions to learn and use AI in journalism studies.

\section{Research Questions}

To meet the objective, the following questions have been taken in consideration:

1. Which external variables of technology acceptance model are working in changing the system's use?

2. Are there any internal constructs working to accelerate the change?

3. Do the journalism students have positive intentions to learn and use AI in journalism?

\section{Research Method and Sampling}

Quantitative method has been followed in this study. To understand the basic knowledge of journalism students about AI and journalism a survey was done on them. 120 participants from 10 different Universities have participated in this survey. All the participants are studying in the field Mass Communication and Journalism and they had a course on Information and Communication technology. Out of the 120 respondents, 88 were males and 42 female students. We take more male students than female ones to reflect the lower ratio of male and female students in the Communication and Journalism discipline of Bangladesh. This is a representative sample because all the participants represent all the necessary features for this research. For example, there are participants from the public university, the private university, the urban area and rural area-based University as well. Most of the participants come from a different economic background. All the 120 participants of this survey represent necessary diversity and background information related with this study.

A questionnaire was developed based on the findings of "New Powers, New Responsibilities: A Global Survey of Journalism and Artificial Intelligence" (Beckett, 2019) conducted by the Google news initiative and POLIS Think tank at LSE. This report was based on a survey of the state of mind and state of play in 71 
news organizations from 32 different countries regarding artificial intelligence (AI) and associated technologies (2020). Their research findings were taken to make the research questionnaire so that we can ask engage student with the latest development on the field of AI and journalism. To understand their thought about AI some ideas were taken from the survey report entitled "What Consumers Really Think about AI: A Global Study" (2020).

\section{Research Findings}

The findings of the survey can be analyzed into three phrases:

1. Finding the existence of variables.

2. Finding the existence of major constructs.

3. Finding out the intentions to use AI.

Here, all these three phrases are interdependent. External variables are influencing the major constructs and thus changing/impacting the use of AI among journalism students. The findings of the survey are as follows.

\section{Finding the Existence of Variables}

\section{Interacting with AI Beforehand}

In the era of social media and internet students are interacting with many AI applications, but the question is, are we capable enough to recognize it? We asked to our respondents, have you ever interacted with Artificial Intelligence technology? We got the following responses Figure 3.

Figure 3. Interaction with Artificial Intelligence Technology

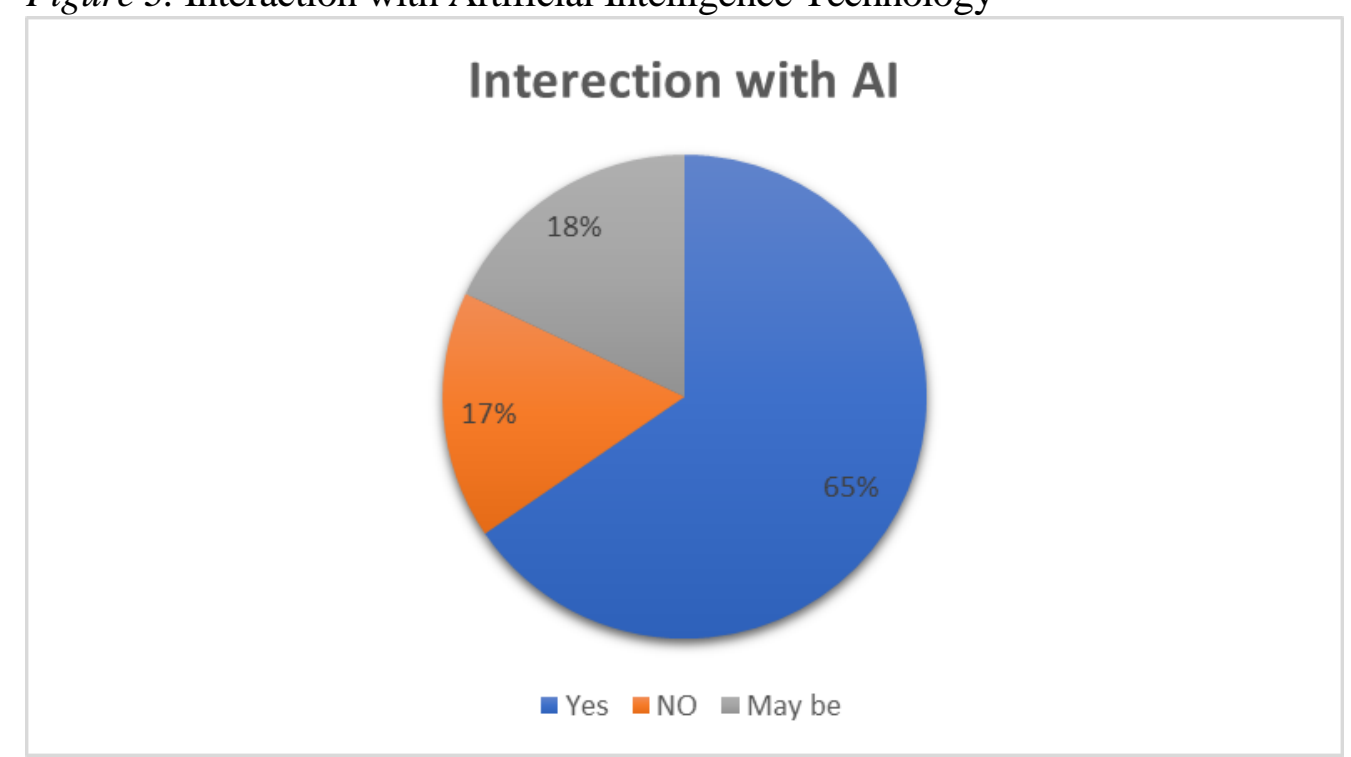


About $65 \%$ have confessed that they had already interacted with Artificial Intelligence technology meanwhile only $17 \%$ respondents have never had an interaction with Artificial intelligence. To have a clear view on their understanding about what kind of AI technology they have used recently, they were asked another question and the questions was which of the following technologies have you used or encountered in the last year? 8 different features were mentioned in the questionnaire and a free to answer option was given for their opinion as well (Figure 4).

Figure 4. Interaction with Artificial Intelligence Technology

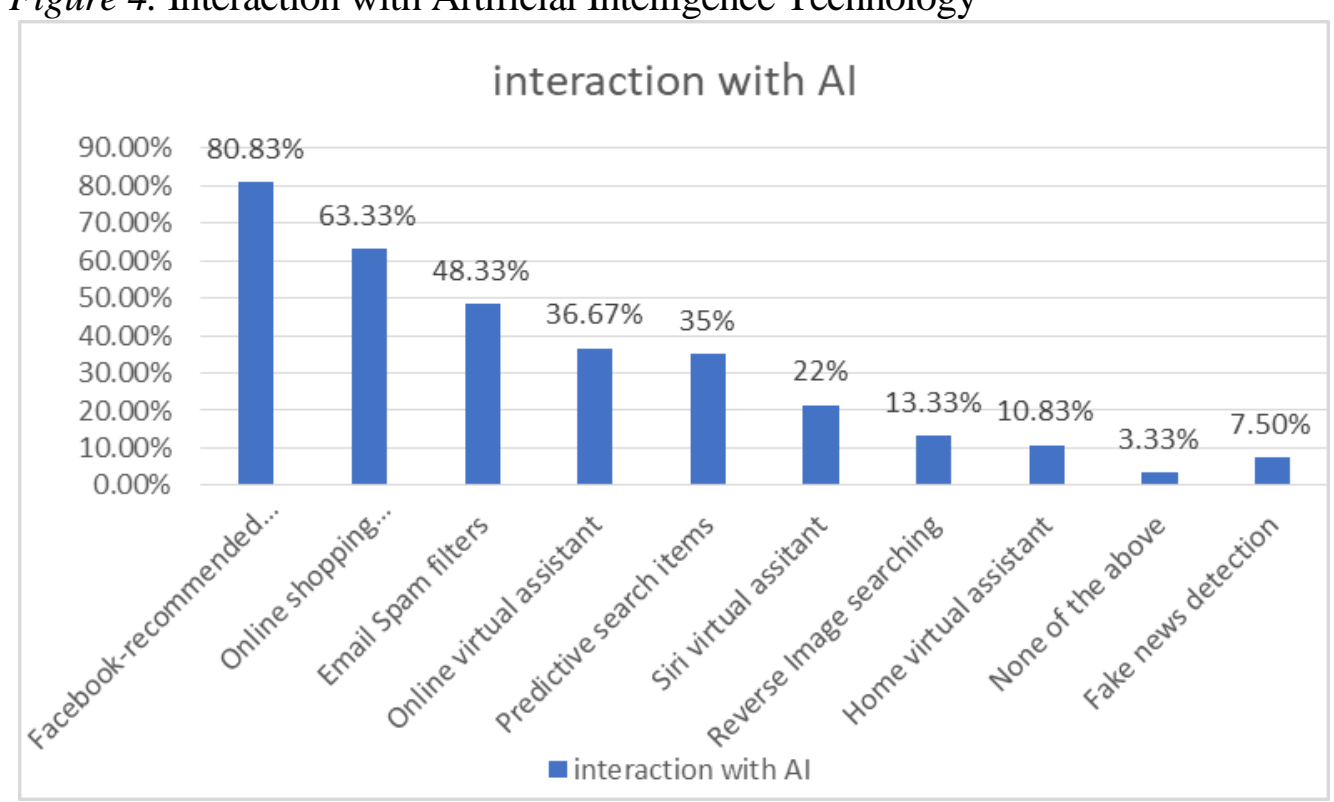

Most of the respondents (almost 80\%) have used Facebook-recommended news, while only $7.5 \%$ of the respondents have interacted with AI for fake news detection. This is a great finding for our research because students are using an AI application which is related with journalism that's why it will be more interesting to see their basic knowledge and preparation for the uses of AI in journalism. More than 63\% students got online shopping recommendation from AI and around $50 \%$ students uses email spam filters. Only $22 \%$ and $10 \%$ students are taking help from Siri virtual assistant and home virtual assistant, respectively. Only 3\% student have not interacted with any of these features.

This result shows the influence of "Experience" variable for the TAM 2 model having more interaction with gadget AI beforehand.

\section{Voluntary Use of AI/ Preferring AI}

A question was asked to our respondents to understand their preferred communication using AI. The question was, when you need any service, what is typically your preferred contact channel? And we got the following responses (Figure 5). 
Figure 5. Contact Channel

\section{Contact Channel}

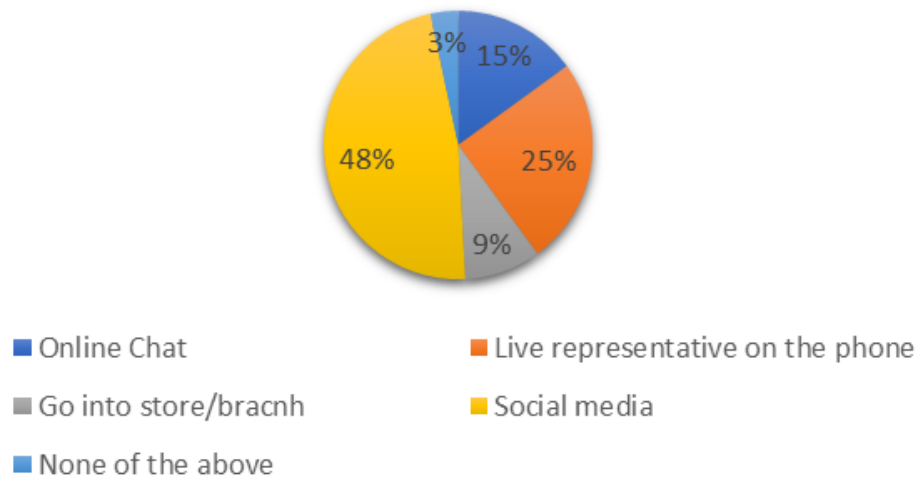

Around $48 \%$ respondents preferred social media especially chatbot and $25 \%$ wants to talk with a person as contact channel when they need any services. Around $15 \%$ respondents will use online chat as medium of contact. It is clear that respondents are choosing contact channel where AI can be used. They prefer chatbot over a human representative which shows the presence of "Voluntariness" variable.

\section{AI and Future Journalism}

Another important variable "Job relevance" is dominantly visible in the result of the survey. Most of the students in journalism believe that AI is the future of journalism. We asked the question are you concerned about the impact that AI might have on journalism (Figure 6).

Figure 6. Impact of AI in Future Journalism

\section{Impact of Al in Future Journalism}

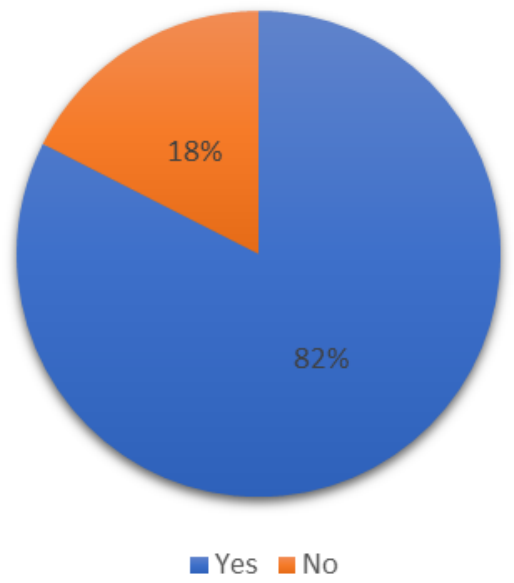


A big number of respondents (almost 82\%) are aware about the impact of AI in future journalism meanwhile only just above $18 \%$ respondents thinks that they are not aware about the impact of $\mathrm{AI}$ in future journalism. It is clear that $\mathrm{AI}$ will have an impact on future journalism but now the question is in which area of journalism it will be more impactful. So we asked; where we can do the best use of $\mathrm{AI}$ and their response was very impressive (Figure 7).

Figure 7. Impact of AI in Future Journalism

\section{Impact of Al in Future Journalism}

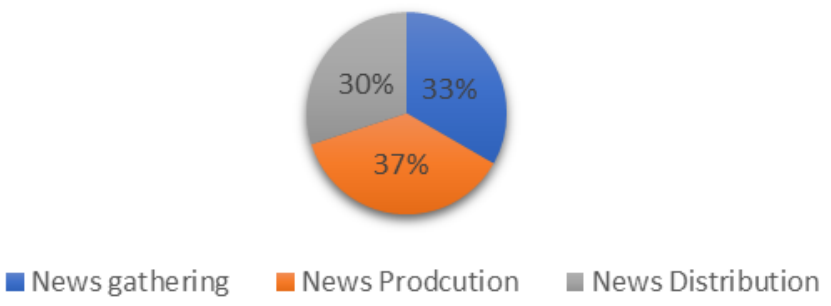

The result clearly shows that AI will have almost equal impact on the three major fields of journalism, i.e., news gathering, news production and news distribution. According to the respondents from news writing to news publishing $\mathrm{AI}$ is equally important to every steps of journalism.

\section{Output Quality of AI}

Most of the journalism students believe that AI performs great by doing several tasks. To understand their preliminary knowledge about the output quality of AI we asked a question, how do you describe what AI can do? We also provide a checkbox where we have mentioned few applications of Artificial intelligence. The findings are shown in Figure 8.

Figure 8. Output Quality of AI

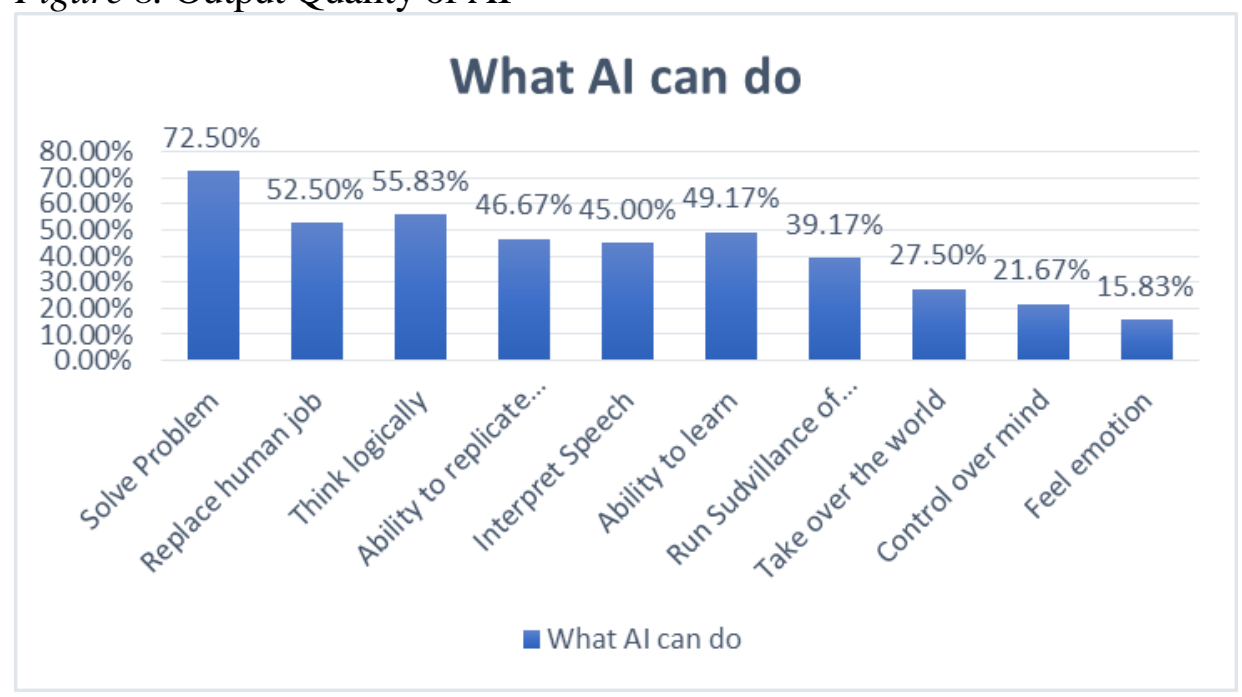


Out of 10 applications, students give more priority to solving problems. Around $72.50 \%$ students believe that AI solve problem, where around $50 \%$ students keep faith on AI's ability to learn while Machine learning is a key factor of Artificial intelligence. More than 50\% students think that AI can think logically, and it can replace human jobs but only $27 \%$ students think that AI can take over the world though it can replace human jobs. The least number of students (only $15 \%$ ) thinks that AI can feel emotion.

\section{AI in Reshaping Journalism}

We also wanted to know specifically about the probable impact of AI in the future of journalism. The question was in which arena you think AI can reshape journalism? We asked this question with multiple options with checkbox (Figure 9).

Figure 9. AI in Reshaping Journalism

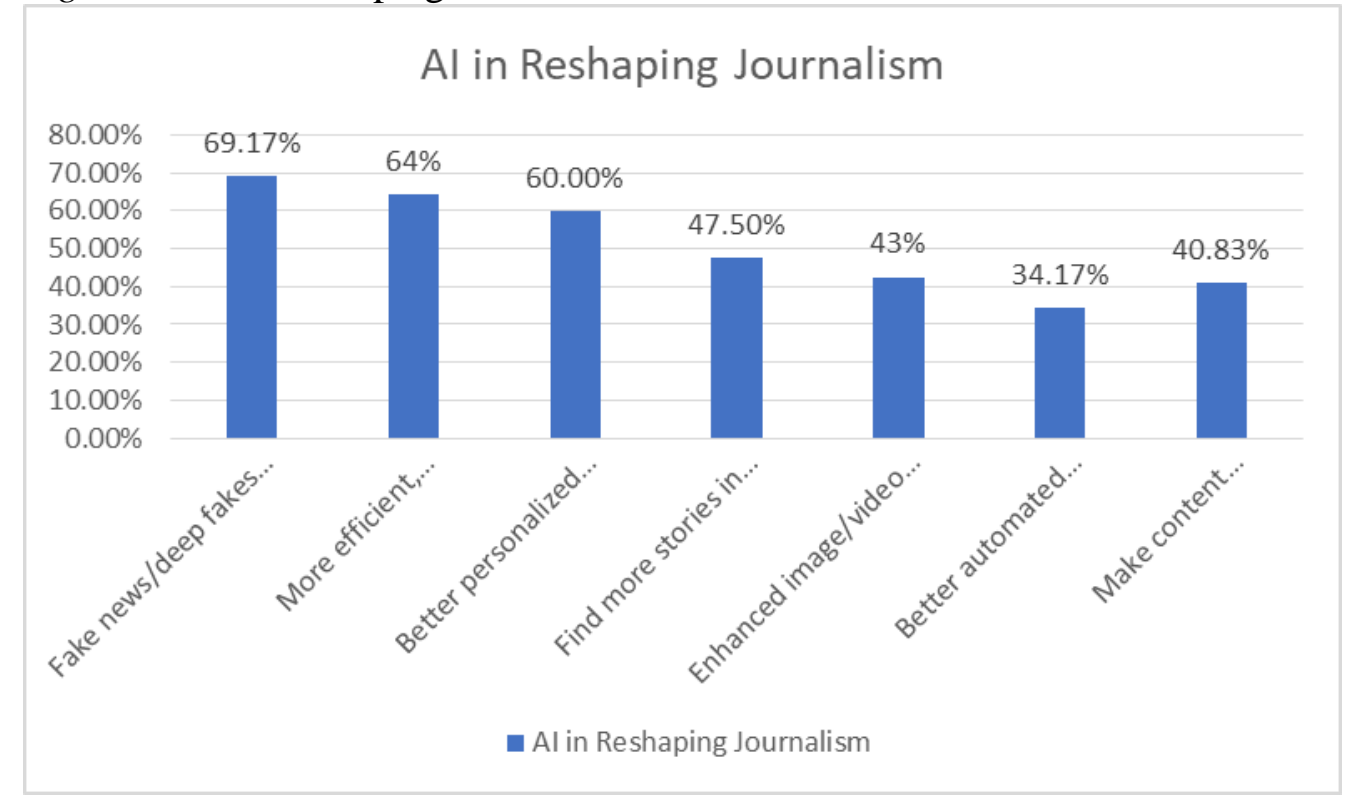

Around $70 \%$ respondents think that we can detect the fake news using AI technologies and $64 \%$ students thinks that we will get more efficient, automated production of content. Around $60 \%$ respondents believe that AI can be useful for better personalized distribution of content and it will also enhance image or video search options. Around $48 \%$ respondent also think that with the help of AI news consumers will find more data in stories and journalist will find more stories in data. More than $34 \%$ respondents also believe that AI will help the media business though dynamic pricing for both for ads and subscriptions. This result shows the presence of the variable "Result Demonstrability" where tangible result are influencing in overall AI use. 


\section{Finding the Existence of Two Major Constructs}

This survey has found the presence of both important constructs "Perceived Usefulness" and "Perceived Ease of Use". The analysis of the survey is as follows:

\section{AI Helping in Daily Life}

$81.67 \%$ of the respondents believe that AI can help them to improve their daily life while only $6.67 \%$ respondents thinks that $\mathrm{AI}$ is not able to improve their daily life. Around 12\% respondents are dilemma regarding this question (Figure 11).

Figure 11. AI Helping in Daily Life

\section{Al Helping Daily Life}

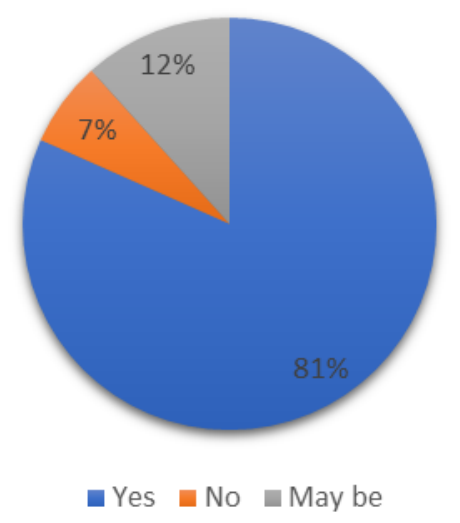

More than $80 \%$ students believe in AI's contribution in daily life (for example: saving time and money) it clearly shows the existence of the construct 'Perceived Usefulness'. Students believe AI is useful for them and that indicates the readiness of Bangladesh in accepting technology.

\section{Comfort Ability in Using AI}

It is important to find out whether Bangladeshi students are always comfortable to work with our colleagues, devices or technologies or not. The following question is asked to our respondents. How comfortable are you/would you be with a work/study/job using Artificial Intelligence to interact with you? (Figure 12). 
Figure 12. Comfortability in Using AI

\section{Comfortability with Al}

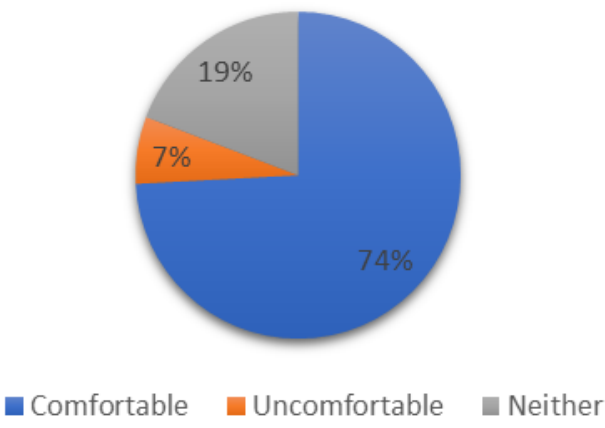

It seems that most of the respondents $74 \%$ are comfortable to interact with where around $7 \%(6.67 \%)$ respondents are not comfortable to interact with Artificial Intelligence. This successfully indicates the presence of another construct "Perceived Ease of Use". The students of Bangladesh are quite techno-freak and using modern gadgets on daily basis. That is why they are more open and comfortable in using AI.

\section{Finding Out the Intention to Use AI}

According to the model of TAM 2, variables are responsible in influencing two constructs (Perceived usefulness and Perceived ease of use) and from the two constructs intention of using the system is created. In the survey, we also found the intention among students on readiness to use AI. They have demonstrated positive intentions in learning AI as a part of their academic coursework. To understand their academic orientation of AI, we asked the question: Did you learn about Artificial Intelligence (AI) in any of the courses that you have studied so far? (Figure 13).

Figure 13. Intention to Use AI

\section{Intention to Use Al}

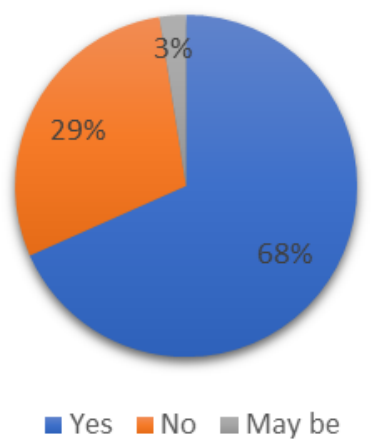


Almost 70\% (68.33\%) students of Communication and Journalism discipline had learned about artificial intelligence (AI) in any of the courses but there was no specific course on Artificial intelligence. Around 29\% students did not have any knowledge on AI in the courses that they have studied so far. Then we asked the most important question of our research: Do you think that the potential role of AI in journalism should be included in the course curriculum? (Figure 14).

Figure 14. Intention to Use AI

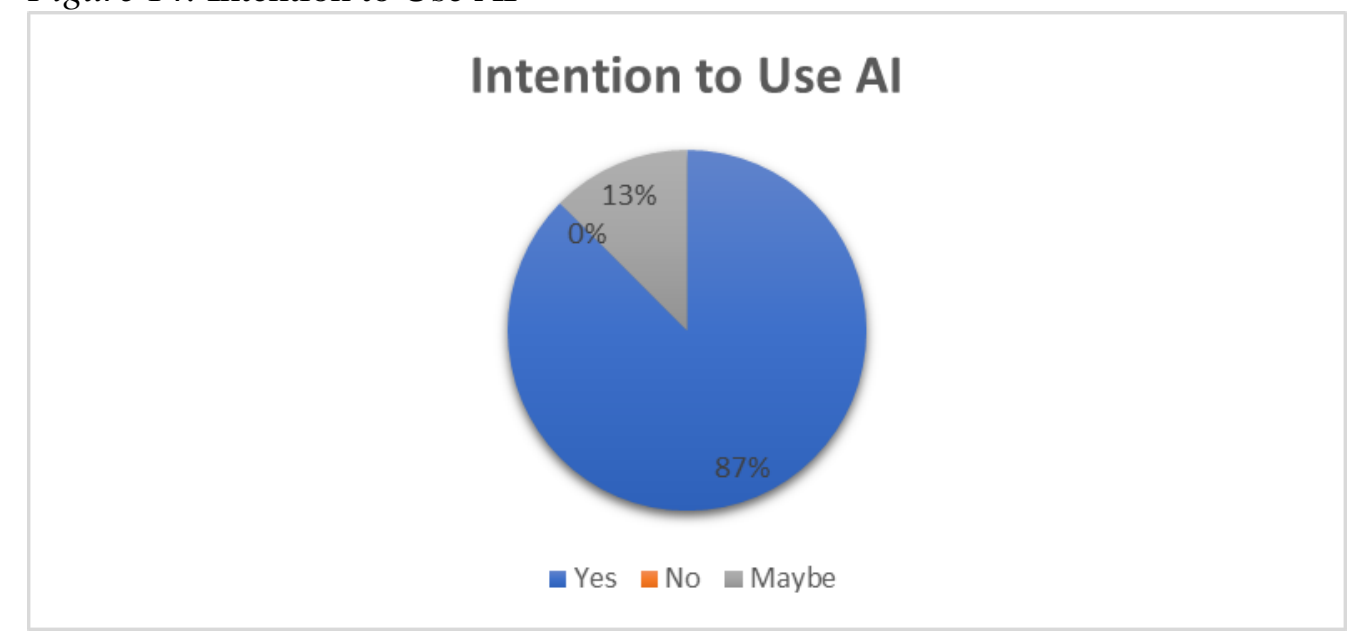

The most interesting fact is that not a single respondent said no about including the potential role of AI in journalism in the course curriculum. More than $87 \%$ respondents agreed on it and around $13 \%$ respondents are in dilemma regarding this issue. This finding gives us a clear overview on the intention of learning $\mathrm{AI}$ and most importantly the necessity of the inclusion of AI in journalism in the course curriculum.

As there is an ongoing debate on ethical perspective of using AI, we have also asked a question regarding the ethical aspects of AI in journalism. We asked specifically: Do you think that using AI in journalism is ethically right? (Figure 15)

Figure 15. Intention to Use AI

\section{Intention to Use Al}

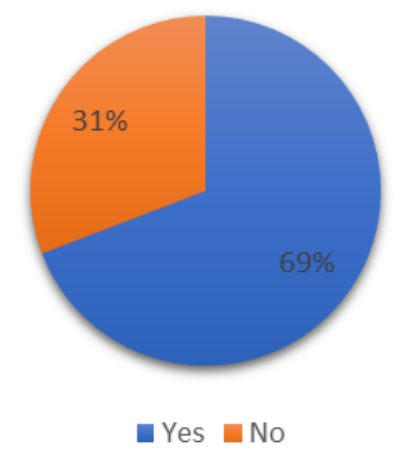


Almost $70 \%$ respondents think that it is ethically right, and about $30 \%$ respondents think that it will be ethically wrong. This shows their welcoming outlook towards studying AI as they understand the necessity of AI in modern era.

\section{Discussion}

Analyzing the results of the survey data based on the TAM 2 model, the overall findings look like as follows (Figure 16).

Figure 16. Analyzing with TAM 2 Model

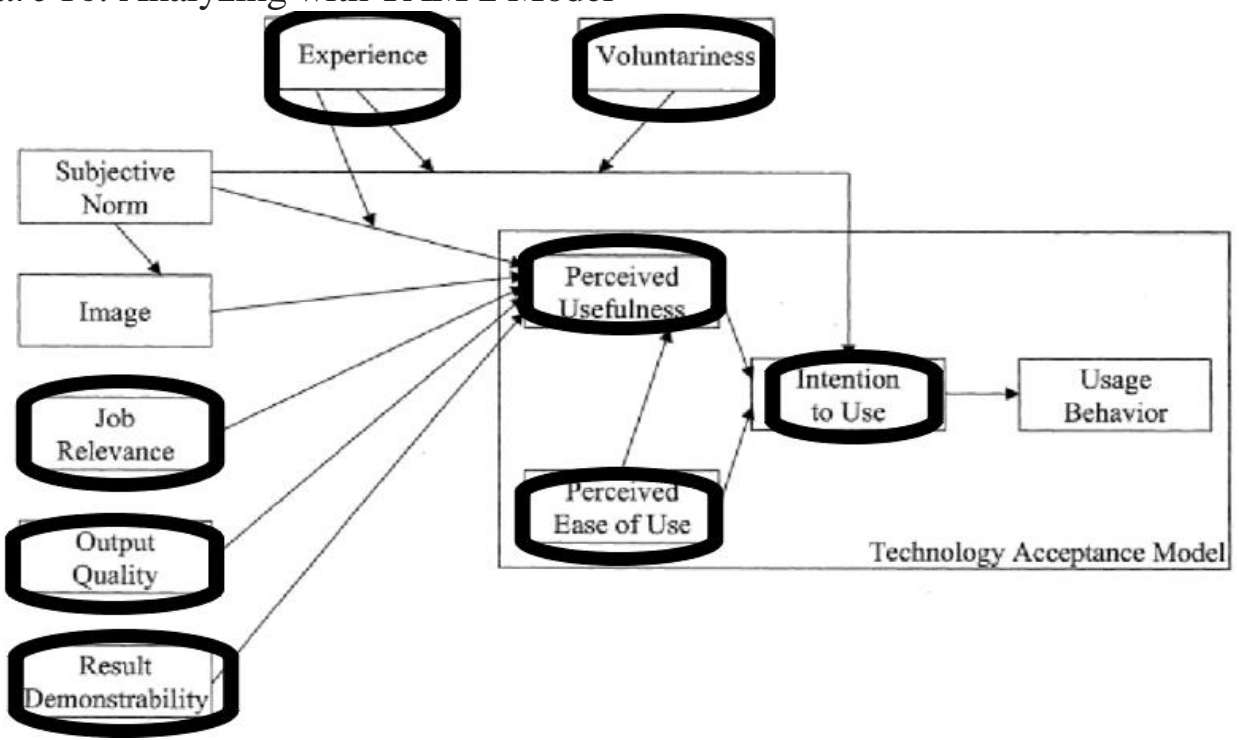

Here, the marked ones are the existing factors found responsible for analyzing AI usage based on technology acceptance model (TAM2). Here, in this survey, five out of seven external variables are found working in social influence and cognitive instrumental process. Two variables subjective norms and images were not found having any kind of impact. This result strongly suggests the fact that usage of AI is not popular enough to make it a subjective norm or enhancing someone's status. Unlike these two, the rest of the five factors are working strongly in self-reported current use and self-predicted future usage.

Being influenced by external variables, two internal constructs (perceived usefulness and perceived ease of use) are also found working positively in showcasing the readiness of Bangladesh in accepting AI. According to the survey, students of journalism are very optimistic about the usefulness of AI and also very comfortable in using them.

All these positive outcomes above are also influencing in changing intentions of students in using AI. The results show that, students have interacted with AI in personal life by far and these are creating the intention of using it in academic and professional level also. The survey result showcases student's increasing expectations and enthusiasm in using AI. All these variables are working together to gather the final outcome of the model, usage behavior. 
So, excluding two external variables (subjective norms and image) Venkatesh and Davis's Technology Acceptance Model (TAM 2) is quite (if not fully) successful in analyzing the readiness of Bangladesh in using AI in journalism.

\section{Conclusion}

From the above discussion, we can conclude that, AI has tremendous importance in the field of journalism. The hypothesis concerning external variables (Hypothesis 1) has been tested in phase 1. It stated having strong influence of five variables on system usage. The second hypothesis that states existence of internal constructs has significant impact on behavioral change also. So, we can easily conclude that the first two hypotheses have been tasted successfully with positive outcomes.

On the other hand, the third hypothesis concerning negative intentions of students to learn and use AI has been found, contradicting earlier results. Results found that the journalism students of Bangladesh are mentally ready for learning, using and experimenting with AI. They have basic knowledge on the concept and are very much eager to learn and use AI at personal and professional levels. This is undoubtedly a good sign for the mainstream journalism industry of Bangladesh.

So the study ends with noteworthy results. Despite having possible risks and challenges, there is no alternative to AI to keep up with modern mainstream journalism. The future journalists of Bangladesh, the students, have mental readiness to learn and accept $\mathrm{AI}$ as a new technology with unlimited personal and professional benefits. All we need to do now is working to ensure huge infrastructural development to get the best outcome of the system usage and thus helping the future generation in serving fast and reliable news to mass people. This study will certainly open a new chapter for the discipline of Mass Communication and Journalism and will be the pioneer study in the research arena of AI and journalism education in Bangladesh.

\section{Acknowledgments}

Our thanks to Athens Institute for Education \& Research for allowing us to modify templates they had developed.

\section{References}

Arkadium (2019). Rise of the machines: how automated journalism is changing newsrooms. Retrieved from: from https://bit.ly/3gTO3rz.

Beckett, C. (2019). New powers, new responsibilities. A global survey of journalism and artificial intelligence. Retrieved from: https://blogs.lse.ac.uk/polis/ 2019/11/18/newpowers-new-responsibilities/. [Accessed 15 April 2020]. 
Biswal, S., Gouda, N. (2020). Artificial intelligence in journalism: a boon or bane? In A. Kulkarni, S. Satapathy (Eds.) Optimization in machine learning and applications (pp. 155-167). Singapore: Springer.

Broussard, M., Diakopoulos, N., Guzman, A., Abebe, R., Dupagne, M., Chuan, C. (2019). Artificial intelligence and journalism. Journalism \& Mass Communication Quarterly, 96(3), 673-695.

Carlson, M. (2015). The robotic reporter: automated journalism and the redefinition of labor, compositional forms, and journalistic authority. Digital Journalism, 3(3), 416431.

Clerwall, C. (2014). Enter the robot journalist: users' perceptions of automated content. Journalism Practice, 8(5), 519-531.

Davis, F. (1986). A technology acceptance model for empirically testing new end-user information systems: theory and results. Doctoral Dissertation. Cambridge, MA: MIT Sloan School of Management.

Davis, F. D., Bagozzi, R. P., Warshaw, P. R. (1992). Development and test of a theory of technological learning and usage. Human Relations 45(7), 660-686.

Dorr, K. N. (2016). Mapping the field of algorithmic journalism. Digital Journalism, 4(6), 700-722.

Elish, M., Hwang, T. (2017). An AI pattern language. $1^{\text {st }}$ Edition. New York: Data \& Society.

Fishbein, M., Azjen, I. (1975). Belief, attitude, intention and behavior. Reading, MA: Addison-Wesley.

Graefe, A. (2016). Guide to automated journalism. Retrieved from: https://www.cjr.org/ tow_center_reports/guide_to_automated_journalism.php. [Accessed 13 April 2020].

Kim, S. (2012). An empirical study on users' intention to use mobile applications. Retrieved from: https://www.researchgate.net/publication/328029 995_Identification _of_external_variables_for_the_Technology_Acceptance_ModelTAM_in_the_asses sment_of_BIM_application_for_mobile_devices. [Accessed 13 April 2020].

Lewis, S., Guzman, A., Schmidt, T. (2019). Automation, journalism, and human-machine communication: rethinking roles and relationships of humans and machines in news. Digital Journalism, 7(4), 409-427.

Lu, H., Li, Y., Chen, M., Kim, H., Serikawa, S. (2018). Brain intelligence: go beyond artificial intelligence. Mobile Networks and Applications, 23(2), 368-375.

Maurer, R. (1997). Transforming resistance. HR Focus, 74(10), 9-10.

Montal, T., Reich, Z. (2017). I, robot. You, journalist. Who is the author? Authorship, bylines and full disclosure in automated journalism. Digital Journalism, 5(7), 829849.

Moore, G. C., Benbasat, I. (1991). Development of an instrument to measure the perceptions of adopting an information technology innovation. Information Systems Research, 2(3), 192-222.

Moses, L. (2017). The Washington Post's robot reporter has published 850 articles in the past year. Digiday. Retrieved from: https://digiday.com/media/washington-postsrobot-reporter-published-500-articles last-year/. [Accessed 15 March 2020].

Napoli, P. M. (2014). Automated media: an institutional theory perspective on algorithmic media production and consumption. Communication Theory, 24(3), 340-360.

O'Neill, M. (Ed.) (2001). Chambers concise dictionary and thesaurus. Edinburgh, Scotland: Chambers Harrap.

Russell, S., \& Norvig, P. (2003). Artificial Intelligence: A Modern Approach (2nd ed.). Upper Saddle River, New Jersey: Prentice Hall.

Sevier, R. A. (2003). Overcoming internal resistance to change. University Business, 6(7), 23. 
Shin, M. (2016). The effect of mobile shopping application characteristics on continuous use intention: focused on technology acceptance model. Retrieved from: https://iop science.iop.org/article/10.1088/1757-899X/401/1/012 027/meta. [Accessed 13 April 2020].

Thurman, N., Dörr, K., Kunert, J. (2017). When reporters get hands-on with robo-writing: professionals consider automated journalism's capabilities and consequences. Digital Journalism, 5(10), 1240-1259.

UNB (2020). Dataful receives Amazon activate grant. Retrieved from: https://bit.ly/3fq VmGN. [Accessed 11 July 2020].

Underwood, C. (2019). Automated journalism - AI applications at New York Times, Reuters, and other media giants. Emerj. Retrieved from: https://emerj.com/ai-sectoroverviews/automated-journalism-applications/. [Accessed 26 May 2020].

Uricchio, W. (2011). The algorithmic turn: photosynth, augmented reality and the changing implications of the image. Visual Studies, 26(1), 25-35.

Venkatesh, V., Davis, F. D. (2000). A theoretical extension of the technology acceptance model: four longitudinal field studies. Management Science, 46(2), 186-204. doi: $10.1287 / \mathrm{mnsc} .46 .2 .186 .11926$

Weeks, L. (2014). Media law and copyright implications of automated journalism. NYU Journal of Intellectual Property and Entertainment Law, 4(1), 67-94.

What Consumers Really Think about AI: A Global Study (2020). Retrieved from: https://www.ciosummits.com/what-consumers-really-think-about-ai.pdf. [Accessed 15 April 2020].

Whittaker, J. (2019). Tech giants, artificial intelligence, and the future of journalism. $1^{\text {st }}$ Edition. New York: Routledge. 



\title{
Shared Selves on Social Media: Examining the Relationship between Real and Ideal Selves of Generation-Y Instagram Users in Turkey
}

\author{
By Dilara Çoşkun ${ }^{*} \&$ Sinan Aşçı ${ }^{ \pm}$
}

\begin{abstract}
Sharing on social media has brought out different communicative affordances in order to construct individuals' identities. In this study, the relationship between real and ideal selves was examined with regard to variables like gender, age, Instagram usage habits, and purposes. In order to reveal the bases of such changes in our self-representation, Adler's individual psychology theory and Goffman's theories on identity and selfrepresentation were reflected on the results of a questionnaire including the Ideal and Real Self-Concept Scale generated by Waugh (2001) and adapted in the context of Turkey by Kaplkiran (2004). In this study, the questionnaire consists of questions on demographic features, Instagram usage habits, and it was conducted with generation-y Instagram users in Turkey, who were recruited via convenience and selective accidental sampling. The results indicated that there is a correlation between individuals' academic self-concept, social self-concept, and self-presentation as subscales. In addition to this, the data revealed that the current presentations of real and ideal selves rarely exist based on academic self-concept and social self-concept. Within this study, how generation-y Instagram users mix and integrate their real or ideal selves is discussed, and some subtle cues to represent their selves on social media platforms are revealed.
\end{abstract}

Keywords: social media, self-concept, real self, ideal self, self-presentation.

\section{Introduction}

Future and ongoing directions in technological developments pave the way for getting individuals surrounded by digital platforms more and more. As discussed in the field of the sociological infrastructure of media and communication, "global village" saying coined by McLuhan (1962) shows that the Internet came into our lives by making the concept real for individuals to experience. Thinking about and commenting on digital platforms enhance the possibilities and opportunities to make the individuals residing in the same or separated places get in touch with each other apart from their social lives. Such new features and assets to offline experiences are in an increase regarding the social media platforms and applications which might be used in everyday life for different reasons like interpersonal communicative affordances, business, education, and fun activities. As the incorporation and reflection of academic, social, and personal information into text and images on social media platforms continues to exist, so do related practices and meanings created and shared by the users. In other words, the very first examples of social media platforms have been structured with the same basis of today's samples and still continue with the same

*Postgraduate Student, Bahçeşehir University, Turkey.

${ }^{ \pm}$Assistant Professor, Bahçeşehir University, Turkey. 
perception among the individuals. That is to say, according to Van Dijk (2006), the most main change even in the old media to new media is the pattern of conversation. Van Djik (2006) stated that "the new media added a substantial new quality: the possibility to combine speech, data and text in one message."

Combining different communicative affordances into one message on social media platforms makes the users' roles uncertain because they become both producer and consumer, which is conceptualized as "prosumer." To put it bluntly, prosumers have made use of "production for use" process, and their social media sharings also become their earnings when they are confronted with the other individuals to represent and share themselves. In other words, it can be understood that the display of selves, activities, messages, or other posts shared by the users on social media platforms create a kind of particular and intentionally revealed expression of "spatial self" which is based on both online and offline instances. The communicative affordances on social media platforms like sharing the posts, using some tags, having a live connection with the other users change the daily lives in a new direction. As also discussed by Indaco and Manovich (2016), this form of usage gives an idea of where activities and locations which the users are interested in, and it allows users to share their experiences and self-presentations. In other words, the shared meanings and meaning-making on social media platforms is based on how individuals have been creating their selves. According to Erikson (1959), a stable and consistent sense of self is one of the key developmental needs of adolescents. To establish their identities, young individuals take their chances by using different interests and presentations of selves because the establishment of identity relies on feedbacks and validation according to Steinberg and Morris (2001). By taking all social media users into account, such an identity formation is a process and very intensely influenced by the settings (Maccoby, 1980) which we have millions of differences based on the platforms and the other users.

According to Hootsuite and We Are Social's analyses of 'Digital in 2020 Report', out of the 7.75 billion people, 4.54 billion are internet users, 3.80 billion are active social media users in 2020 (Hootsuite and We Are Social, 2020). According to 'Digital 2020 in Turkey' (Hootsuite and We Are Social, 2020), out of the 83.88 million people in Turkey, 62.07 million people are internet users, 54 million people are mobile social media users. The time individuals have spent on social media platforms has also increased when compared to the situation in 2019, and it was found that the average social media user spends 2 hours and 51 minutes in a day on social media platforms in 2020. According to the same report with Similarweb, among all social media platforms, Instagram has 3.81 billion active social media users in the world (Hootsuite and We Are Social, 2020). When the local numbers checked regarding Instagram use, Turkey's $83 \%$ of the active social media users have been using Instagram (Hootsuite and We Are Social, 2020). Related to these numbers mentioned in this international report, it is safe to say that Instagram plays an active role in the life of internet users. Starting from this point of view, we recognize that the display of self on social media platforms may consist of different expressions regarding the real and ideal selves. In other words, the spatial self which is performed on social media platforms shows the way how 
we present ourselves and how we have an opportunity to present ourselves to our online audiences, like experiencing a distinction between our real identity and the ideal identity.

Uses of Instagram's communicative affordances point the way to how such specific social media platforms are formed personally by being adapted to the professional fields. In such applications, the connection has been started to get in touch with friends and social environment which is followed by sharing some details about our daily lives. In order to understand and reveal such a distinction between real identities and ideal identities with the help of Instagram's communicative affordances, among generation-y (millennials), Instagram users' mutual tendency has been examined. By considering Instagram-based communicative affordances as part of real and ideal selves, this study provides an interdisciplinary survey of works that study the selves in psychological development and self-presentation. In addition to this, current discussions on userdriven aspects of establishing identities on social media platforms aim to find out how and what kind of basis users as members of generation-y practice on social media platforms like Instagram as one of the applications consisting of both visual and textual affordances. Finally, the basis of this article is going to picturize the Instagram usage and tendencies of generation-y members, and the concepts "ideal self and real self" have been traced with the help of various affordances of Instagram in regard to self-reported ideas.

\section{Literature Review \& Theoretical Background}

\section{Self-Concept and Authentic Identities of Individuals}

Self-concept is an overarching idea we have about who we are - physically, emotionally, socially, spiritually, and in terms of any other aspects which make up who we are (Neill, 2005). As a major term to have been discussed by several leading scholars in humanities, self-concept refers to an executive way of personality and determines how individuals establish a relationship with the world (Çetinkaya-Yıldız and Gençtanırım-Kurt, 2019, p. 446). It can be understood that we form and regulate our own self-concept based on the experiences we have got about ourselves and the world around us. In addition to this, Rogers claims (Ellis et al., 2009) that self is the essence of personality, special and peculiar to him or herself, and never opens to others particularly. That's why the division of "selfconcept" and "self" is different since they are both multidimensional and can be divided into related individual aspects like interpretations of ourselves or experiences and genuine characteristics, respectively.

Self-concept, according to Marsh cited by Waugh (2001), is a sense of one's relation to themselves, and this sense takes shapes with their interpretations of experiences in their environment. In addition to this, it is a kind of subjective way of looking to ourselves. As stated by Çapri (2019), the self-concept takes two other terms with itself: in other words, the real self and ideal self. The latter refers to our thoughts about what we want to become, our purposes and desires for our lives 
(Çapri, 2019). It refers to the self which corresponds to Freud's ideal ego (Ellis et al., 2009). That's why the relationship between real and ideal selves reveals the individuals' psychological health which just comes after their self-images. When these selves are considered as creating self-images in life, some other key concepts related to individuals' identity developments become prominent because selfconceptualization is also based on the individual social interest by getting involved in different environments.

Social interest is known as an essential component of individuals' psychological development. Social interest can be defined with the terms related to the intimacy to the whole society, and it can be seen as connected with every individual's personal value. Regarding its emergence (Karairmak and Aydoğan, 2019, p. 156), the social interest needs to be fed and processed in spite of being a common trait for every individual who has. In this process, to summarize it all, social interest starts in children's first cared relationship in their lives and becomes extended with relations they have got in school and other areas where they socialize. When these children get proper and enough social interest, they start transferring their inferiority feeling to power that helps them become superior in their lives. By doing so, they shape their own self-perceptions, understanding of life, and existence in the community they are in. As Adler cited by Hatipoğlu (2019, p. 96) stated, every individual is part of a social community, and selfperception is one of the functions of their social identities. This identity transfer to the others with whom the individuals are in contact may be exemplified like sharing life details, political thoughts, talking about a book they have read, fashion styles in terms of their own interests which have an effect on individuals' social identity. As things stand, the relationship between social interest and inferiority feeling affects our self-perception in life.

The experience mentioned and discussed in different perspectives is significant for shaping the self-concept and self-perception, and the experience merged into the social interest affects the individuals' ideal and real selves. By taking experience into consideration, relationships with our caregivers, parents, friends, are counted as good assets to be involved in our life perceptions and the environments where we have interaction with the world.

The self-conceptualization, in this regard, can be assumed and discussed more by the individuals who are completed with their early adulthood, like generation-y; when generation-y is mostly considered as digital natives because they started experiencing digital technology as soon as they were born, and they already have known it all their lives. Prensky (2001) coined the concept of "digital natives" because of the fact that members involved in generation-y have mostly become the "native speakers of the digital language of computers and the Internet." However, there are more than digital natives when the years regarding generation-y were thought. In this respect, the environment where members of generation-y are mostly used to express themselves is the digital social areas existing in life - not only because they are directly involved in digital social areas, but also they are urged to get involved by their peers. This argument paves the way for questioning what social media platforms in the digital age make our ideal and real selves because of holding the opportunities which make individuals behave with their 
superior and inferior feelings and show their "self-descriptive" profiles in the community created and accepted by them.

\section{Social Media, Perspectives on how to Create Representations, and Hybrid Identities}

Social media use has become increasingly widespread among adolescents as access to smartphones has also increased (Lenhart, 2015). With the incorporation of daily and personal information turned into some textual basis, visual content, and video streamings on social media platforms, the practices and given meanings that are involved in these digital traces have become more engaged in users' daily lives. Social networking sites (SNSs) are defined by Boyd and Ellison (2007) as web-based services which allow individuals to construct a public or semi-public profile within a bounded system, articulate a list of other users with whom they share a connection, and view and traverse their list of connections made by others within the system. The basics which can be inferred from the common definition of social media are web-based services, applications, and user interactions along with the developed information technologies. With the help of these basics, social media platforms are used for socialization by the users in a virtual environment using various communicative actions. Applying for the communicative affordances in technically offline interactions to social media platforms, self-presentation online is enacted by the users: for instance, a post shared on a social media platform through a network intentionally or unintentionally created by themselves. By doing so, according to Litt (2012, p. 331), social media users rely on "the mental conceptualization of the people with whom we are communicating" to inform their self-presentation behaviors.

Goffman's theories on identity and self-presentation - "front stage" and "back stage" presentations - have been incredibly valid for analyzing the social behaviors on social media platforms by focusing on the situations, contexts, and also audiences (Hogan, 2010). In addition to these ideas, Butler's concept of performativity has been used for discussions on mobility and subjectivity (Gregson and Rose, 2000) for understanding and analyzing online representations. Considering both ideas, the content of shared images, videos, status updates, profiles, interests and even comments on the profiles helps social media users present a curated version of themselves. According to Donath and Boyd (2004), within social media platforms, users create their "self-descriptive" profiles and build a network with their personal connections. That's why sharing some content on social media platforms can be a good example of self-presentation because the users can decide on how they would like to represent themselves and reveal the differences and similarities between their ideal and real selves regarding their interests on those platforms.

Users construct and present themselves mostly in many different times during their lives. Therefore, social media platforms are where individuals have been performing, describing themselves, and sharing some content instantly. As mentioned and discussed by Manovich (2001), new media refers to not something stable eternally because it consists of various forms with uncountable affordances. 
Hereby, individuals have the opportunity to create endless modes of "selfdescriptive" forms on social media platforms. Following this opportunity, it can be inferred that users' self-descriptive profiles consist of some actions changing according to their personal networks (followings and followers), desires, qualities, current trends they are interested in. These actions affect the relationship between users' ideal and real selves, and their attitudes are changed and shaped as well. These changed attitudes reflect on users' ideal schemas and real schemas combination.

Making one of two distinct things -ideal and real selves- paves the way for discussion of the hybridity based on identities reflected on social media platforms. According to Sakamoto (1996), hybridity represents coexistence and retains a sense of difference and tension between two cultures, but without assuming hierarchy. Applied to ideal and real selves, there is nothing new, but a new form of transfer from the offline to the online. As Barker (1999) claims "hybrid identities cannot be seen as essential identities but as part of a widespread "cut \& mix" of cultural forms in the context of globalization" (p. 73). That's why the social media platforms where individuals as users have the opportunity to interact with previously known and unknown individuals from similar or different contexts can be accepted as context collapse because of the ability to create another self for each user.

"Context collapse" is one of the problems and concerns which a verifiable online identity brings with it because social technologies make it difficult to vary self-presentation based on environment or audience (Marwick and Boyd, 2011). According to Papacharissi (2002), individuals creating online profiles for different reasons use some digital tokens like pictures, avatars, nicknames, etc. to represent themselves, and these items become a symbolic marker of establishing and displaying their identities. The way how real and ideal selves are concerned and questioned regarding social media platforms is often explained through such customization, but one important part is based on users' comments and ideas on their own uses.

\section{Method}

\section{The Present Study}

This study is to expand on existing studies of online self-presentation by examining the relationship between real and ideal selves of generation-y Instagram users in Turkey and the efforts they take to achieve based on their own purposes and uses. The study applies to a larger developmental question of whether there is any correlation between real and ideal selves of millennials on Instagram in terms of academic self-concept, social self-concept, and self-presentation. Importantly, the study explores the correlation between real - ideal selves and other factors like gender, the frequency of sharing posts, the time spent daily on Instagram, and the duration of being an Instagram user. In addition to these goals, to better understand and examine the context of real and ideal selves, the question of whether there is 
any difference between real - ideal selves and the previously mentioned demographic factors is also explored. To tackle these goals, a questionnaire was conducted with generation-y Instagram users in Turkey, which is a common approach to get to know in studies of self-presentation. Despite the fact that selfreported studies do not possibly reflect the accurate situation, users' perceptions spark off other meaningful discussions to ground the other studies theoretically or practically.

\section{Methodology}

Three hundred ten millennials (233 females, 76 males, 1 did not want to respond) participated in this study, who were recruited via convenience (based on using Instagram and being a member of generation-y) and selective accidental sampling; millennials known to the researchers were contacted through social media and asked if they accepted to share the questionnaire on their social media profiles. Participants received no compensation for completing this survey.

Participants completed a questionnaire for collecting demographic information like year of birth and gender, for knowing the habits on Instagram, the frequency of sharing posts on Instagram, the reasons why posts are shared and Instagram is used, time spent daily on Instagram, and the duration of being an Instagram user. In addition to this part of the questionnaire, the Ideal and Real Self-Concept Scale developed by Waugh (2001) was used, which was translated and tested by Kapıkıran (2004) regarding its reliability and validity in the context of Turkey. The scale consists of 90 items, 45 of which represent ideal self-concept and the rest does real self-concept. In the context of the questionnaire, every ideal self-concept item has been followed by the real self-concept item. Waugh's (2001) scale originally has a 5-point Likert Scale, and the scale has 3 subscales: academic selfconcept, social self-concept, and self-presentation. In the Ideal and Real SelfConcept Scale, the academic self-concept subscale is connected with talents, perceptions of success, and trust in success. In addition to this, social self-concept is related to friendships and family relations. Finally, self-presentation refers to an individual's own perception of their physical, cognitive, emotional case. Kapıkıran (2004) used the same subscales with a 4-point Likert Scale: namely, O for Never, 1 for Sometimes, 2 for Usually, and 3 for Always. In this study, the Ideal and Real Self-Concept Scale was implemented into the demographic and uses questionnaire to be administered by courtesy of Necla Acun Kapıkıran who was the first scholar to use the scale in Turkish.

\section{Reliability Analysis of the Questionnaire}

The data collected through recruiting generation-y Instagram users into the questionnaire were analyzed using Statistical Package for Social Sciences (SPSS) software version 22.0, and the reliability analyses were performed for the items in the Ideal and Real Self-Concept Scale and its subscales: namely, academic selfconcept, social self-concept, and self-presentation. 
Table 1. Cronbach's Alpha Levels for the Ideal and Real Self-Concept Scale

\begin{tabular}{|l|c|c|}
\hline Subscales \& Scale & $\boldsymbol{N}$ of Items & Cronbach's Alpha \\
\hline Academic Self-Concept & 30 & 0.930 \\
\hline Social Self-Concept & 30 & 0.931 \\
\hline Self-Presentation & 30 & 0.912 \\
\hline Total & 90 & 0.967 \\
\hline
\end{tabular}

As seen in Table 1, Cronbach's alpha levels for academic self-concept, social self-concept, and self-presentation are $0.930,0.931,0.912$, respectively. The Cronbach's alpha levels for the whole Ideal and Real Self-Concept Scale is 0.967. Regarding Alpha coefficient, the reliability of scales are as follows (Akbulut, 2010): if $0.00 \leq \alpha<0.40$, not reliable, if $0.40 \leq \alpha<0.60$, low reliable, if $0.60 \leq \alpha<$ 0.80 , quite reliable, if $0.80 \leq \alpha<1.00$, highly reliable. Based upon the Cronbach's alpha levels for the subscales and the whole scale, the questionnaire is highly reliable.

\section{Results}

Core Values of the Questionnaire (Demographic Features). Among 310 millennials voluntarily participated in this study, $75.2 \%$ and $24.5 \%$ of the participants were female and male, respectively. In addition to this, only $0.3 \%$ of all did not want to specify their gender. The participants' years of birth are between 1980 and 1986 (13.2\%), 1987 and 1993 (30.6\%), and 1994 and 2000 (56.1\%).

Core Values of the Questionnaire (Instagram Usages). The participants were asked to reveal the possible habits and usages of Instagram appealing to them more. Table 2 shows the prevalence of what kinds of habits become patterns among generation-y Instagram users.

Table 2. Instagram Usage Habits of Participants

\begin{tabular}{|l|c|}
\hline Habits and/or Usages & \% of Participants \\
\hline I share stories. & $79 \%$ \\
\hline I share posts. & $73.5 \%$ \\
\hline I use highlights for the stories. & $35.5 \%$ \\
\hline I watch the IGTV. & $31.3 \%$ \\
\hline $\begin{array}{l}\text { I use the "close friends" filter while } \\
\text { sharing stories. }\end{array}$ & $17.1 \%$ \\
\hline I use face filters while sharing stories. & $14.8 \%$ \\
\hline None of the above-mentioned. & $11.3 \%$ \\
\hline
\end{tabular}

Table 2 which depicts "Instagram Usage Habits of Participants," only $11.3 \%$ do not do any of the previously mentioned habits on Instagram. When the percentages considered, most of the participants share some content as stories and posts, and fewer participants make use of some filters for the content or sharing options. In addition to this, $45.5 \%$ of the participants share a post monthly. Following this percentage, $19.7 \%$ and $18.1 \%$ share posts on Instagram once a week and once or twice a year, respectively. Less than these percentages, $4.2 \%$ of 
participants do once a day, and $2.3 \%$ does more than two posts daily. Above all, only $10.3 \%$ of participants do have Instagram accounts but do not share any posts.

Figure 1. Time Spent Daily on Instagram

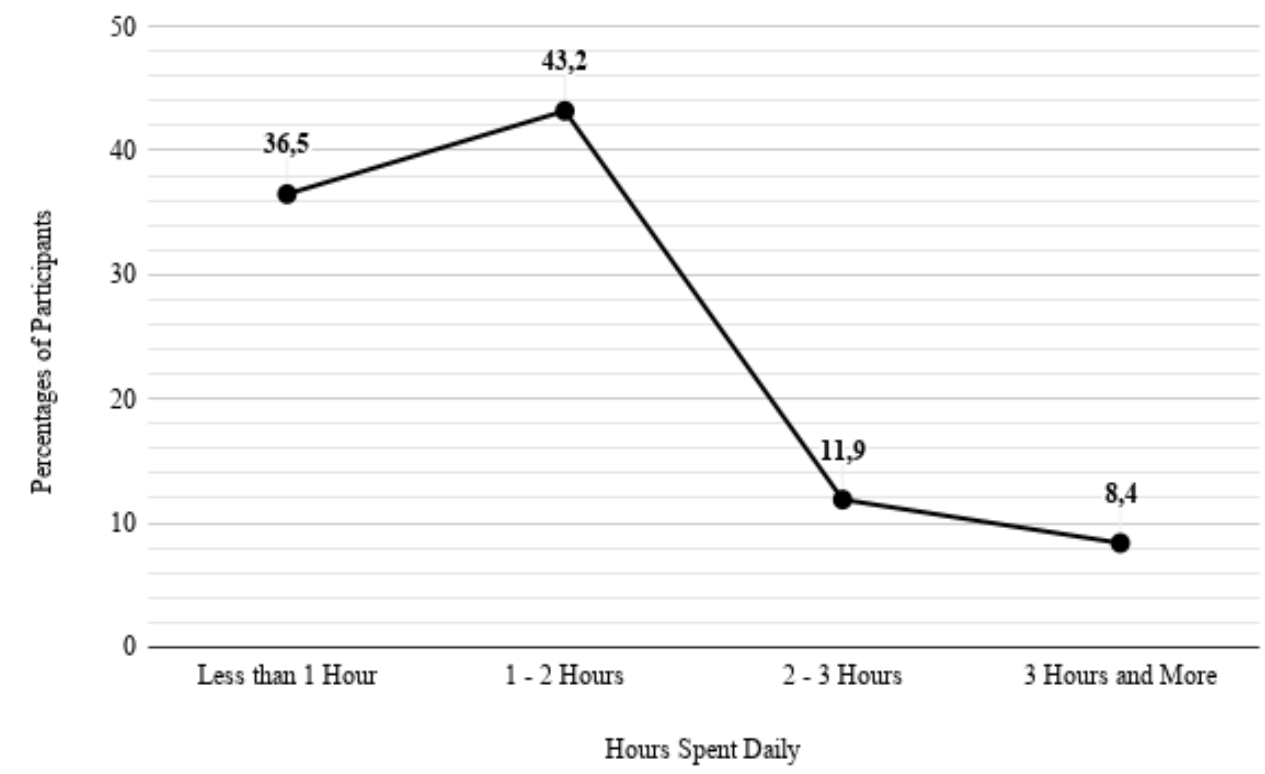

As shown in Figure 1, 43.2\% of participants spend 1 or 2 hours daily for using Instagram, and $36.5 \%$ of them less than 1 hour. $11.9 \%$ and $8.4 \%$ spend their time on Instagram daily for 2 or 3 hours and 3 hours or more, respectively. Together with the time spent daily, participants were also asked how long they have been using Instagram: 59.7\% of participants have been using Instagram for 4 or 6 years. $20.3 \%$ have used for $7+$ years, and $20 \%$ for less than 3 years.

Table 3. Priorities and Personal Reasons for Sharing Posts

\begin{tabular}{|l|c|c|c|c|}
\hline Statements & $\begin{array}{c}\text { N of } \\
\text { Participants }\end{array}$ & Sum & Mean & Std. Deviation \\
\hline Priorities for Sharing Posts & 310 & $1,252.00$ & $\mathbf{4 . 0 3 8 7}$ & 1.07868 \\
\hline I share my achievements. & 261 & 819.00 & $\mathbf{3 . 1 3 7 9}$ & 1.66067 \\
\hline I share my own photos. & 273 & $1,163.00$ & $\mathbf{4 . 2 6 0 1}$ & 1.62532 \\
\hline I share where I go or visit. & 266 & $1,165.00$ & $\mathbf{4 . 3 7 9 7}$ & 1.30116 \\
\hline $\begin{array}{l}\text { I share photos with my } \\
\text { friends. }\end{array}$ & 270 & $1,066.00$ & $\mathbf{3 . 9 4 8 1}$ & 1.34589 \\
\hline I share my activities. & 269 & 943.00 & $\mathbf{3 . 5 0 5 6}$ & 1.40792 \\
\hline $\begin{array}{l}\text { I write about my } \\
\text { experiences. }\end{array}$ & 250 & 386.00 & $\mathbf{1 . 5 4 4 0}$ & 1.11941 \\
\hline
\end{tabular}

The statements in the scale of priorities for sharing posts were given points between 1 and 6 as their means are seen in Table 3. When the answers (mean) of participants are examined, all the statements were scored above 3, but only the statement "I write about my experiences" was given the lowest point as 1.5440 . Regarding the participants' personal reasons to use Instagram during their daily 
lives, most of the participants with $74.2 \%$ have been using for following their connections - which is followed by $73.5 \%$ for learning and exploring. The least percentage for personal reasons to use Instagram belongs to "making sales as an employer" with $3.5 \%$.

\section{Subscales of the Questionnaire}

In the questionnaire used in this study, three different subscales were used to reveal the academic self-concept, social self-concept and self-presentation, all of which consist of 30 statements and are scored with a 4-point Likert Scale: namely, ofor Never, 1 for Sometimes, 2 for Usually, and 3 for Always.

Table 4. Academic Self-Concept Subscale Results

\begin{tabular}{|c|c|c|c|}
\hline Statements & $\begin{array}{c}N \text { of } \\
\text { Participants }\end{array}$ & Mean & Std. Deviation \\
\hline $\begin{array}{l}\text { 1. I wish I were capable of obtaining good grades } \\
\text { (marks) at university. }\end{array}$ & 691.00 & 2.2290 & 0.99308 \\
\hline $\begin{array}{l}\text { 2. I am capable of obtaining good grades (marks) } \\
\text { at university. }\end{array}$ & 769.0 & 2.481 & 0.6521 \\
\hline $\begin{array}{l}\text { 3. I wish I were smart enough to cope with } \\
\text { university work. }\end{array}$ & 657.00 & 2.1194 & 1.10396 \\
\hline 4. I am smart enough to cope with university work. & 783.00 & 2.5258 & 0.62134 \\
\hline $\begin{array}{l}\text { 5. I wish I were proud of my ability in academic } \\
\text { work at university. }\end{array}$ & 690.00 & 2.2258 & 1.07063 \\
\hline $\begin{array}{l}\text { 6. I am proud of my ability in academic work at } \\
\text { university. }\end{array}$ & 637.00 & 2.0548 & 0.93141 \\
\hline $\begin{array}{l}\text { 7. I wish I felt good about my academic work at } \\
\text { university. }\end{array}$ & 721.00 & 2.3258 & 0.99203 \\
\hline $\begin{array}{l}\text { 8. I feel good about my academic work at } \\
\text { university. }\end{array}$ & 578.00 & 1.8645 & 0.92836 \\
\hline $\begin{array}{l}\text { 9. I wish I were able to get the results I would like } \\
\text { at university. }\end{array}$ & 742.00 & 2.3935 & 0.95867 \\
\hline $\begin{array}{l}\text { 10. I am able to get the results I would like at } \\
\text { university. }\end{array}$ & 678.00 & 2.1871 & 0.81083 \\
\hline $\begin{array}{l}\text { 11. I wish I felt good about my assignment marks } \\
\text { (grades) at university. }\end{array}$ & 738.00 & 2.3806 & 0.93318 \\
\hline $\begin{array}{l}\text { 12. I feel good about my assignment marks } \\
\text { (grades) at university. }\end{array}$ & 632.00 & 2.0387 & 0.82739 \\
\hline $\begin{array}{l}\text { 13. I wish I were proud of my achievements at } \\
\text { university. }\end{array}$ & 725.00 & 2.3387 & 0.99422 \\
\hline $\begin{array}{l}\text { 14. I am proud of my achievements at the } \\
\text { university. }\end{array}$ & 657.00 & 2.1194 & 0.88968 \\
\hline $\begin{array}{l}15 . \text { I wish I got satisfied with my academic work } \\
\text { at university. }\end{array}$ & 742.00 & 2.3935 & 0.94849 \\
\hline $\begin{array}{l}\text { 16. I am satisfied with my academic work at } \\
\text { university. }\end{array}$ & 537.00 & 1.7323 & 0.93956 \\
\hline $\begin{array}{l}\text { 17. I wish I became happy with the academic } \\
\text { work I did at university. }\end{array}$ & 720.00 & 2.3226 & 0.94122 \\
\hline $\begin{array}{l}\text { 18. I am happy with the academic work I do at the } \\
\text { university. }\end{array}$ & 613.00 & 1.9774 & 0.89015 \\
\hline $\begin{array}{l}\text { 19. I wish I could achieve a high level at the } \\
\text { university. }\end{array}$ & 726.00 & 2.3419 & 0.98164 \\
\hline
\end{tabular}




\begin{tabular}{|l|c|c|c|}
\hline 20. I achieve at a high level at university. & 566.00 & 1.8258 & 0.84492 \\
\hline $\begin{array}{l}\text { 21. I wish I felt as good as the other people in my } \\
\text { classes at university. }\end{array}$ & 606.00 & 1.9548 & 1.16498 \\
\hline $\begin{array}{l}\text { 22. I feel as good as the other people in my } \\
\text { classes at university. }\end{array}$ & 707.00 & 2.2806 & 0.76869 \\
\hline $\begin{array}{l}\text { 23. I wish I felt involved in academic life at } \\
\text { university. }\end{array}$ & 663.00 & 2.1387 & 1.05670 \\
\hline 24. I feel involved in academic life at university. & 508.00 & 1.6387 & 1.03894 \\
\hline 25. I wish I had a rapport with lecturers at university. & 675.00 & 2.1774 & 1.00684 \\
\hline 26. I have a rapport with lecturers at university. & 662.00 & 2.1355 & 0.92486 \\
\hline 27. I wish I felt good in university classes. & 727.00 & 2.3452 & 0.97222 \\
\hline 28. I feel good in university classes. & 663.00 & 2.1387 & 0.82642 \\
\hline 29. I wish I were sure of myself at university. & 755.00 & 2.4355 & 0.94202 \\
\hline 30. I am sure of myself at university. & 681.00 & 2.1968 & 0.83025 \\
\hline
\end{tabular}

When the mean values as seen in Table 4 were examined in this subscale regarding the academic self-concept of participants, statements numbered with 8 , 16, 18, 20, 21, and 24 were given less than 2 points (negative). However, the rest was scored with more than 2 points (positive).

Table 5. Social Self-Concept Subscale Results

\begin{tabular}{|l|c|c|c|}
\hline Statements & $\begin{array}{c}\text { N of } \\
\text { Participants }\end{array}$ & Mean & Std. Deviation \\
\hline $\begin{array}{l}\text { 1. I wish I had persons of my age and sex } \\
\text { enjoy my company. }\end{array}$ & 712.00 & 2.2968 & 1.01875 \\
\hline $\begin{array}{l}\text { 2. I have persons of my age and sex enjoy } \\
\text { my company. }\end{array}$ & 766.00 & 2.4710 & 0.77007 \\
\hline $\begin{array}{l}\text { 3. I wish I had my same-sex friends who } \\
\text { have confidence in me. }\end{array}$ & 743.00 & 2.3968 & 0.97575 \\
\hline $\begin{array}{l}\text { 4. I have my same-sex friends who have } \\
\text { confidence in me. }\end{array}$ & 809.00 & 2.6097 & 0.62776 \\
\hline $\begin{array}{l}\text { 5. I wish I were popular with others of the } \\
\text { same-sex and age. }\end{array}$ & 724.00 & 2.3355 & 1.00341 \\
\hline $\begin{array}{l}\text { 6. I am popular with others of the same- } \\
\text { sex and age. }\end{array}$ & 763.00 & 2.4613 & 0.74398 \\
\hline $\begin{array}{l}\text { 7. I wish I were able to get along well } \\
\text { with others of the same sex. }\end{array}$ & 734.00 & 2.3677 & 0.96555 \\
\hline $\begin{array}{l}\text { 8. I am able to get along well with others } \\
\text { of the same sex. }\end{array}$ & 774.00 & 2.4968 & 0.72294 \\
\hline $\begin{array}{l}\text { 9. I wish I were an important person for } \\
\text { my same-sex friends. }\end{array}$ & 696.00 & 2.2452 & 0.98100 \\
\hline $\begin{array}{l}\text { 10. I am an important person for my } \\
\text { same-sex friends. }\end{array}$ & 713.00 & 2.3000 & 0.77814 \\
\hline $\begin{array}{l}\text { 11. I wish I had persons of my age and } \\
\text { opposite-sex enjoy my company. }\end{array}$ & 704.00 & 2.2710 & 0.96750 \\
\hline $\begin{array}{l}\text { 12. I have persons of my age and } \\
\text { opposite-sex enjoy my company. }\end{array}$ & 748.00 & 2.4129 & 0.78239 \\
\hline $\begin{array}{l}\text { 13. I wish I had my opposite-sex friends } \\
\text { who have confidence in me. }\end{array}$ & 726.00 & 2.3419 & 0.96501 \\
\hline $\begin{array}{l}\text { 14. I have my opposite-sex friends who } \\
\text { have confidence in me. }\end{array}$ & 744.00 & 2.4000 & 0.84455 \\
\hline $\begin{array}{l}\text { 15. I wish I were popular with others of } \\
\text { the same age and opposite-sex. }\end{array}$ & 701.00 & 2.2613 & 0.97847 \\
\hline
\end{tabular}




\begin{tabular}{|l|c|c|c|}
\hline $\begin{array}{l}\text { 16. I am popular with others of the same } \\
\text { age and opposite-sex. }\end{array}$ & 715.00 & 2.3065 & 0.80429 \\
\hline $\begin{array}{l}\text { 17. I wish I were able to get along well } \\
\text { with others of the opposite sex. }\end{array}$ & 702.00 & 2.2645 & 0.97594 \\
\hline $\begin{array}{l}\text { 18. I am able to get along well with } \\
\text { others of the opposite sex. }\end{array}$ & 734.00 & 2.3677 & 0.79659 \\
\hline $\begin{array}{l}\text { 19. I wish I were an important person to } \\
\text { my opposite-sex friends. }\end{array}$ & 679.00 & 2.1903 & 1.00125 \\
\hline $\begin{array}{l}\text { 20. I am an important person to my } \\
\text { opposite-sex friends. }\end{array}$ & 686.00 & 2.2129 & 0.84751 \\
\hline $\begin{array}{l}\text { 21. I wish I were treated fairly by my } \\
\text { family. }\end{array}$ & 752.00 & 2.4258 & 0.99480 \\
\hline 22. I am treated fairly by my family. & 737.00 & 2.3774 & 0.79814 \\
\hline 23. I wish I were trusted by my family. & 776.00 & 2.5032 & 0.96122 \\
\hline 24. I am trusted by my family. & 814.00 & 2.6258 & 0.65010 \\
\hline 25. I wish I were loved by my family. & 778.00 & 2.5097 & 0.95780 \\
\hline 26. I am loved by my family. & 843.00 & 2.7194 & 0.60361 \\
\hline $\begin{array}{l}\text { 27. I wish I knew my family was proud } \\
\text { of me. }\end{array}$ & 778.00 & 2.5097 & 0.96117 \\
\hline 28. I know my family is proud of me. & 813.00 & 2.6226 & 0.65072 \\
\hline 29. I wish I felt wanted at home. & 726.00 & 2.3419 & 1.03928 \\
\hline 30. I feel wanted at home. & 798.00 & 2.5742 & 0.73690 \\
\hline
\end{tabular}

When the mean values as seen in Table 5 were examined in this subscale regarding the social self-concept of participants, all the statements were scored more than 2: therefore, it reveals that there is a positive approach towards this type of self-concept among generation-y Instagram users.

Table 6. Self-Presentation Subscale Results

\begin{tabular}{|l|c|c|c|}
\hline Statements & $N$ of Participants & Mean & Std. Deviation \\
\hline $\begin{array}{l}\text { 1. I wish I were an attractive } \\
\text { person. }\end{array}$ & 705.00 & 2.2742 & 0.98153 \\
\hline 2. I am an attractive person. & 553.00 & 1.7839 & 0.87118 \\
\hline $\begin{array}{l}\text { 3. I wish I were just as nice as I } \\
\text { should be. }\end{array}$ & 723.00 & 2.3323 & 0.94984 \\
\hline 4. I am just as nice as I should be. & 618.00 & 1.9935 & 0.83992 \\
\hline $\begin{array}{l}\text { 5. I wish I were of good physical } \\
\text { body appearance. }\end{array}$ & 750.00 & 2.4194 & 0.89132 \\
\hline $\begin{array}{l}\text { 6. I am of good physical body } \\
\text { appearance. }\end{array}$ & 558.00 & 1.8000 & 0.83531 \\
\hline $\begin{array}{l}\text { 7. I wish I felt that others like my } \\
\text { physical appearance. }\end{array}$ & 684.00 & 2.2065 & 1.02523 \\
\hline $\begin{array}{l}\text { 8. I feel that others like my } \\
\text { physical appearance. }\end{array}$ & 541.00 & 1.7452 & 0.84927 \\
\hline $\begin{array}{l}\text { 9. I wish I did not want to change } \\
\text { anything about myself. }\end{array}$ & 669.00 & 2.1581 & 1.05397 \\
\hline $\begin{array}{l}\text { 10. I do not want to change } \\
\text { anything about myself. }\end{array}$ & 394.00 & 1.2710 & 1.00039 \\
\hline $\begin{array}{l}\text { 11. I wish I were confident in } \\
\text { myself. }\end{array}$ & 777.00 & 2.5065 & 0.93734 \\
\hline 12. I am confident in myself. & 691.00 & 2.2290 & 0.84136 \\
\hline $\begin{array}{l}\text { 13. I wish I became a cheerful } \\
\text { person. }\end{array}$ & 759.00 & 2.4484 & 0.94282 \\
\hline
\end{tabular}




\begin{tabular}{|l|c|c|c|}
\hline 14. I am a cheerful person. & 717.00 & 2.3129 & 0.81381 \\
\hline $\begin{array}{l}\text { 15. I wish I got satisfied with } \\
\text { myself. }\end{array}$ & 783.00 & 2.5258 & 0.89097 \\
\hline 16. I am satisfied with myself. & 650.00 & 2.0968 & 0.82654 \\
\hline 17. I wish I had respect for myself. & 792.00 & 2.5548 & 0.92181 \\
\hline 18. I have respect for myself. & 764.00 & 2.4645 & 0.76558 \\
\hline $\begin{array}{l}\text { 19. I wish I became a worthwhile } \\
\text { person. }\end{array}$ & 794.00 & 2.5613 & 0.88192 \\
\hline 20. I am a worthwhile person. & 746.00 & 2.4065 & 0.78577 \\
\hline $\begin{array}{l}\text { 21. I wish I were a trustworthy } \\
\text { person. }\end{array}$ & 786.00 & 2.5355 & 0.94357 \\
\hline 22. I am a trustworthy person. & 861.00 & 2.7774 & 0.47474 \\
\hline 23. I wish I were an honest person. & 783.00 & 2.5258 & 0.95750 \\
\hline 24. I am an honest person. & 837.00 & 2.7000 & 0.53092 \\
\hline $\begin{array}{l}\text { 25. I wish I were someone on } \\
\text { whom my family can rely. }\end{array}$ & 785.00 & 2.5323 & 0.96404 \\
\hline $\begin{array}{l}\text { 26. I am someone on whom my } \\
\text { family can rely. }\end{array}$ & 846.00 & 2.7290 & 0.60000 \\
\hline $\begin{array}{l}\text { 27. I wish I were someone on } \\
\text { whom my friends can rely. }\end{array}$ & 789.00 & 2.5452 & 0.93627 \\
\hline $\begin{array}{l}\text { 28. I am someone on whom my } \\
\text { friends can rely. }\end{array}$ & 859.00 & 2.7710 & 0.48518 \\
\hline $\begin{array}{l}\text { 29. I wish I were a person valued } \\
\text { by others. }\end{array}$ & 760.00 & 2.4516 & 0.95323 \\
\hline $\begin{array}{l}\text { 30. I am a person valued by } \\
\text { others. }\end{array}$ & 745.00 & 2.4032 & 0.73866 \\
\hline
\end{tabular}

Regarding the mean values of the self-presentation subscale in Table 6, the statements - except 2, 4, 6, 8, and 10 - were scored as more than 2, which shows that the rest of the statements plays a positive role among the participants for their self-presentation.

\section{Test of Normality}

An assessment regarding the normality of data is a prerequisite for statistical tests. Following the results of the test of normality, normal data demonstrate underlying assumptions in using parametric or nonparametric tests. As stated by Can (2014), if Sig. value is greater than 0.05, the data is accepted as passed the normality test. In an adverse way, if Sig. value is less than 0.05 , the data are not consistent with distribution. In this study, when the test of normality is examined, the data are not consistent with the distribution $(0.00, \mathrm{p}<0.05)$ regarding the academic self-concept, social self-concept, and self-presentation. Therefore, as nonparametric tests, Mann Whitney U and Kruskal Wallis tests are going to be applied for both scales as seen in Table 7 . 
Table 7. Results of Test of Normality

\begin{tabular}{|l|c|c|c|}
\hline \multirow{2}{*}{} & \multicolumn{3}{|c|}{ Kolmogorov-Smirnov } \\
\cline { 2 - 4 } & Statistic & df & Sig. \\
\hline Academic Self-Concept & 0.088 & 309 & 0.000 \\
\hline Social Self-Concept & 0.129 & 309 & 0.000 \\
\hline Self-Presentation & 0.117 & 309 & 0.000 \\
\hline
\end{tabular}

\section{Correlation Analysis}

Correlation analysis is a statistical technique to reveal how strongly two variables are related to each other or to show the degree of association between two of them. According to Baş (2013), correlation coefficients changes between -1 and $+1(-1 \leq \mathrm{r} \leq+1)$ : it refers to "very weak" if between 0.00 and 0.25 , "weak" if between 0.26 and 0.49 , "moderate" if between 0.50 and 0.69 , "strong" if between 0.70 and 0.89 , "very strong" if between 0.90 and 1.00 . When this relationship is positive, it refers to a linear relationship: however, it refers to a non-linear relationship if negative.

H1. There is a meaningful relationship between the academic selfconcept, the social self-concept, and the self-presentation.

Table 8. Correlation Analysis of the Subscales

\begin{tabular}{|c|c|c|c|c|}
\hline & & $\begin{array}{c}\text { Academic } \\
\text { Self-Concept }\end{array}$ & $\begin{array}{c}\text { Social } \\
\text { Self-Concept }\end{array}$ & $\begin{array}{c}\text { Self- } \\
\text { Presentation }\end{array}$ \\
\hline Academic & $\begin{array}{l}\text { Pearson Correlation (r) } \\
\text { Sig. (p) } \\
\text { N } \\
\end{array}$ & $\begin{array}{c}1 \\
310 \\
\end{array}$ & & \\
\hline Social & $\begin{array}{l}\text { Pearson Correlation (r) } \\
\text { Sig. (p) } \\
\text { N }\end{array}$ & $\begin{array}{c}0.674 * * \\
0.000 \\
310\end{array}$ & $\begin{array}{c}1 \\
310\end{array}$ & \\
\hline Self-Presentation & $\begin{array}{l}\text { Pearson Correlation (r) } \\
\text { Sig. (p) } \\
\text { N }\end{array}$ & $\begin{array}{c}0.656^{* * *} \\
0.000 \\
310 \\
\end{array}$ & $\begin{array}{c}0.843^{* *} \\
0.000 \\
310\end{array}$ & $\begin{array}{c}1 \\
310 \\
\end{array}$ \\
\hline
\end{tabular}

A correlation analysis was applied to understand the relationship between the subscales: namely, the academic self-concept, the social self-concept, and the selfpresentation. When the analysis seen in Table 8 was examined,

- There is a positive relationship between the academic self-concept and the social self-concept, and it is meaningful $(0.00, \mathrm{p}<0.01)$. The correlation coefficient $(r)$ of this relationship is 0.674 , and the strength of the relationship is moderate.

- There is a positive relationship between the academic self-concept and the self-presentation, and it is meaningful $(0.00, \mathrm{p}<0.01)$. The correlation coefficient ( $r$ ) of this relationship is 0.656 , and the strength of the relationship is moderate. 
- There is a positive relationship between social self-concept and selfpresentation, and it is meaningful $(0.00, \mathrm{p}<0.01)$. The correlation coefficient (r) of this relationship is 0.843 , and the strength of the relationship is high.

H2. There is a meaningful relationship between gender and the subscales (the academic self-concept, the social self-concept, and the selfpresentation).

Table 9. Correlation Analysis of Gender and the Subscales

\begin{tabular}{|c|c|c|c|c|c|}
\hline & & $\begin{array}{l}\text { Academic } \\
\text { Self- } \\
\text { Concept }\end{array}$ & $\begin{array}{c}\text { Social } \\
\text { Self-Concept }\end{array}$ & $\begin{array}{c}\text { Self- } \\
\text { Presentation }\end{array}$ & Gender \\
\hline Academic & $\begin{array}{l}\text { Pearson Correlation (r) } \\
\text { Sig. (p) } \\
\text { N }\end{array}$ & $\begin{array}{c}1 \\
310 \\
\end{array}$ & & & $\begin{array}{c}-0.294 * * \\
0.000 \\
310 \\
\end{array}$ \\
\hline Social & $\begin{array}{l}\text { Pearson Correlation (r) } \\
\text { Sig. (p) } \\
\text { N }\end{array}$ & $\begin{array}{c}0.674 * * \\
0.000 \\
310\end{array}$ & $\begin{array}{c}1 \\
310 \\
\end{array}$ & & $\begin{array}{c}-0.300 * * \\
0.000 \\
310\end{array}$ \\
\hline Self-Presentation & $\begin{array}{l}\text { Pearson Correlation (r) } \\
\text { Sig. (p) } \\
\text { N }\end{array}$ & $\begin{array}{c}0.656 * * \\
0.000 \\
310 \\
\end{array}$ & $\begin{array}{c}0.843 * * \\
0.000 \\
310 \\
\end{array}$ & $\begin{array}{c}1 \\
310 \\
\end{array}$ & $\begin{array}{c}-0.267 * * \\
0.000 \\
310\end{array}$ \\
\hline Gender & $\begin{array}{l}\text { Pearson Correlation (r) } \\
\text { Sig. (p) } \\
\text { N }\end{array}$ & $\begin{array}{c}-0.294 * * \\
0.000 \\
310\end{array}$ & $\begin{array}{c}-0.300 * * \\
0.000 \\
310\end{array}$ & $\begin{array}{c}-0.267 * * \\
0.000 \\
310\end{array}$ & $\begin{array}{c}1 \\
310\end{array}$ \\
\hline
\end{tabular}

A correlation analysis was applied to understand the relationship between gender and the subscales: namely, the academic self-concept, the social selfconcept, and the self-presentation. When the analysis seen in Table 9 was examined,

- There is a negative relationship between gender and academic selfconcept, and it is meaningful $(0.00, \mathrm{p}<0.01)$. The correlation coefficient $(\mathrm{r})$ of this relationship is -0.294 , and the strength of the relationship is weak.

- There is a negative relationship between gender and social self-concept, and it is meaningful $(0.00, \mathrm{p}<0.01)$. The correlation coefficient $(\mathrm{r})$ of this relationship is -0.300 , and the strength of the relationship is weak.

- There is a negative relationship between gender and self-presentation, and it is meaningful $(0.00, \mathrm{p}<0.01)$. The correlation coefficient $(\mathrm{r})$ of this relationship is -0.267 , and the strength of the linear relationship is weak.

H3. There is a meaningful relationship between the year of birth and the subscales (the academic self-concept, the social self-concept, and the selfpresentation). 
Table 10. Correlation Analysis of Year of Birth and the Subscales

\begin{tabular}{|ll|c|c|c|c|}
\hline & $\begin{array}{c}\text { Academic } \\
\text { Self-Concept }\end{array}$ & $\begin{array}{c}\text { Social } \\
\text { Self-Concept }\end{array}$ & $\begin{array}{c}\text { Self- } \\
\text { Presentation }\end{array}$ & $\begin{array}{c}\text { Year of } \\
\text { Birth }\end{array}$ \\
\hline Academic & Pearson Correlation (r) & 1 & $0.674^{* *}$ & $0.656^{* *}$ & -0.061 \\
& & 0.000 & 0.000 & 0.286 \\
& Sig. (p) & 310 & 310 & 310 & 310 \\
\hline Social & Pearson Correlation (r) & $0.674^{*}$ & 1 & $0.843^{* *}$ & -0.037 \\
& Sig. (p) & 0.000 & & 0.000 & 0.521 \\
& $\mathrm{~N}$ & 310 & 310 & 310 & 310 \\
\hline Self-Presentation & Pearson Correlation (r) & $0.656^{* *}$ & $0.843^{* *}$ & 1 & $-0.115^{*}$ \\
& Sig. (p) & 0.000 & 0.000 & & 0.044 \\
& $\mathrm{~N}$ & 310 & 310 & 310 & 310 \\
\hline Year of Birth & Pearson Correlation (r) & -0.061 & -0.037 & $-0.115^{*}$ & 1 \\
& Sig. (p) & 0.286 & 0.521 & 0.044 & \\
& $\mathrm{~N}$ & 310 & 310 & 310 & 310 \\
\hline
\end{tabular}

**Correlation is significant at the 0.01 level (2-tailed).

*Correlation is significant at the 0.05 level (2-tailed).

A correlation analysis was applied to understand the relationship between year of birth and the subscales: namely, the academic self-concept, the social selfconcept, and the self-presentation. When the analysis seen in Table 10 was examined,

- There is no meaningful relationship between the year of birth and academic self-concept $(0.86, \mathrm{p}>0.05)$.

- There is no meaningful relationship between the year of birth and social self-concept $(0.86, \mathrm{p}>0.05)$.

- There is a negative relationship between the year of birth and selfpresentation, and it is meaningful $(0.04, \mathrm{p}<0.05)$. The correlation coefficient (r) of this relationship is -.115 , and the strength of the relationship is very weak.

H4. There is a meaningful relationship between the frequency of post sharing and the subscales (the academic self-concept, the social selfconcept, and the self-presentation).

Table 11. Correlation Analysis of the Frequency of Post Sharing and the Subscales

\begin{tabular}{|ll|c|c|c|c|}
\hline & $\begin{array}{c}\text { Academic } \\
\text { Self- } \\
\text { Concept }\end{array}$ & $\begin{array}{c}\text { Social } \\
\text { Self-Concept }\end{array}$ & $\begin{array}{c}\text { Self- } \\
\text { Presentation }\end{array}$ & $\begin{array}{c}\text { Post Sharing } \\
\text { Frequency }\end{array}$ \\
\hline Academic & Pearson Correlation (r) & 1 & $0.670^{* *}$ & $0.652^{* *}$ & -0.100 \\
& Sig. (p) & 309 & 0.000 & 0.000 & 0.080 \\
& N & 309 & 309 & 310 \\
\hline Social & Pearson Correlation (r) & $0.670^{* *}$ & 1 & $0.841--$ & $-0.117^{*}$ \\
& Sig. (p) & 0.000 & & 0.000 & 0.039 \\
& N & 309 & 309 & 309 & 310 \\
\hline Self-Presentation & Pearson Correlation (r) & $0.652^{* *}$ & $0.841--$ & 1 & $-0.145^{*}$ \\
& Sig. (p) & 0.000 & 0.000 & & 0.011 \\
& N & 309 & 309 & 309 & 310 \\
\hline Post Sharing & Pearson Correlation (r) & -0.100 & $-0.117^{*}$ & $-0.145^{*}$ & 1 \\
Frequency & Sig. (p) & 0.080 & 0.039 & 0.011 & \\
& $\mathrm{~N}$ & 310 & 310 & 310 & 310 \\
\hline
\end{tabular}

**Correlation is significant at the 0.01 level (2-tailed).

*Correlation is significant at the 0.05 level (2-tailed). 
A correlation analysis was applied to understand the relationship between the frequency of post sharing and the subscales: namely, the academic self-concept, the social self-concept, and the self-presentation. When the analysis seen in Table 11 was examined,

- There is no meaningful relationship between the frequency of post sharing and academic self-concept $(0.80, \mathrm{p}>0.05)$.

- There is a negative relationship between the frequency of post sharing and social self-concept, and it is meaningful $(0.00, \mathrm{p}<0.05)$. The correlation coefficient $(r)$ of this relationship is -0.117 , and the strength of the relationship is very weak.

- There is a negative relationship between the frequency of post sharing and self-presentation, and it is meaningful $(0.00, \mathrm{p}<0.05)$. The correlation coefficient ( $r$ ) of this relationship is -0.145 , and the strength of the relationship is very weak.

H5. There is a meaningful relationship between time spent daily on Instagram and the subscales (the academic self-concept, the social selfconcept, and the self-presentation).

Table 12. Correlation Analysis of Time Spent Daily on Instagram and the Subscales

\begin{tabular}{|ll|c|c|c|c|}
\hline & $\begin{array}{c}\text { Academic } \\
\text { Self-Concept }\end{array}$ & $\begin{array}{c}\text { Social } \\
\text { Self-Concept }\end{array}$ & $\begin{array}{c}\text { Self- } \\
\text { Presentation }\end{array}$ & $\begin{array}{c}\text { Time Spent } \\
\text { Daily }\end{array}$ \\
\hline Academic & Pearson Correlation (r) & 1 & $0.674^{* *}$ & $0.656^{* *}$ & $0.117^{*}$ \\
& Sig. (p) & 310 & 0.000 & 0.000 & 0.039 \\
& $\mathrm{~N}$ & 310 & 310 & 310 \\
\hline \multirow{5}{*}{ Social } & Pearson Correlation (r) & $0.674^{* *}$ & 1 & $0.843^{* *}$ & $-0.115^{*}$ \\
& Sig. (p) & 0.000 & & 0.000 & 0.044 \\
& $\mathrm{~N}$ & 310 & 310 & 309 & 310 \\
\hline Self-Presentation & Pearson Correlation (r) & $0.656^{* *}$ & $0.843^{* *}$ & 1 & $0.160^{* *}$ \\
& Sig. (p) & 0.000 & 0.000 & & 0.005 \\
& $\mathrm{~N}$ & 310 & 309 & 310 & 310 \\
\hline Time Spent & Pearson Correlation (r) & $0.117^{*}$ & $-0.115^{*}$ & $0.160^{* *}$ & 1 \\
Daily & 0.039 & 0.044 & 0.005 & \\
& Sig. (p) & 310 & 310 & 310 & 310 \\
\hline & $\mathrm{N}$ & & & \\
\hline
\end{tabular}

*Correlation is significant at the 0.05 level (2-tailed).

A correlation analysis was applied to understand the relationship between time spent daily on Instagram and the subscales: namely, the academic selfconcept, the social self-concept, and the self-presentation. When the analysis seen in Table 12 was examined,

- There is a positive relationship between time spent daily on Instagram and academic self-concept, and it is meaningful $(0.03, \mathrm{p}<0.05)$. The correlation coefficient ( $r$ ) of this relationship is 0.117, and the strength of the relationship is very weak.

- There is a positive relationship between time spent daily on Instagram and social self-concept, and it is meaningful $(0.04, \mathrm{p}<0.05)$. The correlation 
coefficient ( $r$ ) of this relationship is 0.115 , and the strength of the relationship is very weak.

- There is a positive relationship between time spent daily on Instagram and self-presentation, and it is meaningful $(0.00, \mathrm{p}<0.01)$. The correlation coefficient (r) of this relationship is 0.160 , and the strength of the relationship is very weak.

H6. There is a meaningful relationship between the duration of being an Instagram user and the subscales (the academic self-concept, the social self-concept, and the self-presentation).

Table 13. Correlation Analysis of Time Spent Daily on Instagram and the Subscales

\begin{tabular}{|ll|c|c|c|c|}
\hline & $\begin{array}{c}\text { Academic } \\
\text { Self- } \\
\text { Concept }\end{array}$ & $\begin{array}{c}\text { Social } \\
\text { Self-Concept }\end{array}$ & $\begin{array}{c}\text { Self- } \\
\text { Presentation }\end{array}$ & $\begin{array}{c}\text { Membership } \\
\text { Duration }\end{array}$ \\
\hline Academic & Pearson Correlation (r) & 1 & $0.674^{* *}$ & $0.656^{* *}$ & -0.045 \\
& Sig. (p) & 310 & 0.000 & 0.000 & 0.429 \\
& $\mathrm{~N}$ & 310 & 310 & 310 \\
\hline Social & Pearson Correlation (r) & $0.674^{* *}$ & 1 & $0.843^{* *}$ & 0.050 \\
& Sig. (p) & 0.000 & & 0.000 & 0.380 \\
& $\mathrm{~N}$ & 310 & 310 & 310 & 310 \\
\hline Self-Presentation & Pearson Correlation (r) & $0.656^{* *}$ & $0.843^{* *}$ & 1 & 0.023 \\
& Sig. (p) & 0.000 & 0.000 & & 0.687 \\
& $\mathrm{~N}$ & 310 & 310 & 310 & 310 \\
\hline Membership & Pearson Correlation (r) & -0.045 & 0.050 & 0.023 & 1 \\
Duration & Sig. (p) & 0.429 & 0.380 & 0.687 & \\
& $\mathrm{~N}$ & 310 & 310 & 310 & 310 \\
\hline \multirow{2}{*}{ **. Correlation is significant at the 0.01 level (2-tailed). } & & &
\end{tabular}

A correlation analysis was applied to understand the relationship between the duration of being an Instagram user and the subscales: namely, the academic selfconcept, the social self-concept, and the self-presentation. When the analysis seen in Table 13 was examined, there is not a meaningful relationship between the duration of being an Instagram user and the academic self-concept $(0.42, p>0.05)$, the social self-concept $(0.38, \mathrm{p}>0.05)$, and the self-presentation $(0.68, \mathrm{p}>0.05)$.

H7. There is a meaningful relationship between reasons for sharing posts and the subscales (the academic self-concept, the social self-concept, and the self-presentation). 
Table 14. Correlation Analysis of Reasons to Share and the Subscales

\begin{tabular}{|ll|c|c|c|c|}
\hline & $\begin{array}{c}\text { Academic } \\
\text { Self-Concept }\end{array}$ & $\begin{array}{c}\text { Social } \\
\text { Self-Concept }\end{array}$ & $\begin{array}{c}\text { Self- } \\
\text { Presentation }\end{array}$ & $\begin{array}{c}\text { Reasons to } \\
\text { Share }\end{array}$ \\
\hline Academic & Pearson Correlation (r) & 1 & $0.674^{* *}$ & $0.656^{* *}$ & 0.054 \\
& Sig. (p) & 310 & 0.000 & 0.000 & 0.347 \\
& $\mathrm{~N}$ & 310 & 310 & 310 \\
\hline Social & Pearson Correlation (r) & $0.674^{* *}$ & 1 & $0.843^{* *}$ & 0.089 \\
& Sig. (p) & 0.000 & & 0.000 & 0.120 \\
& $\mathrm{~N}$ & 310 & 310 & 310 & 310 \\
\hline Self-Presentation & Pearson Correlation (r) & $0.656^{* *}$ & $0.843^{* *}$ & 1 & 0.069 \\
& Sig. (p) & 0.000 & 0.000 & & 0.224 \\
& $\mathrm{~N}$ & 310 & 310 & 310 & 310 \\
\hline Reasons to & Pearson Correlation (r) & 0.054 & 0.089 & 0.069 & 1 \\
Share & Sig. (p) & 0.347 & 0.120 & 0.224 & \\
& $\mathrm{~N}$ & 310 & 310 & 310 & 310 \\
\hline \multirow{2}{***}{ Correlation is significant at the 0.01 level (2-tailed). } & & &
\end{tabular}

A correlation analysis was applied to understand the relationship between the duration of being an Instagram user and the subscales: namely, the academic selfconcept, the social self-concept, and the self-presentation. When the analysis seen in Table 14 was examined, there is not a meaningful relationship between users' reasons to share posts and the academic self-concept $(0.34, \mathrm{p}>0.05)$, the social self-concept $(0.12, \mathrm{p}>0.05)$, and the self-presentation $(0.22, \mathrm{p}>0.05)$.

\section{Tests of Differences}

With the help of tests of differences, the perceptions of the current scale based on demographic basis and the differences between demographic groups regarding this perception are examined.

H8. There is a difference between gender and the subscales (the academic self-concept, the social self-concept, and the self-presentation).

Table 15. Differences between Gender and the Subscales

\begin{tabular}{|c|c|c|c|c|c|c|}
\hline Variable & Test & Dimensions & Groups & $\begin{array}{l}\text { Mean } \\
\text { Rank }\end{array}$ & $\mathbf{P}$ & Comment \\
\hline \multirow{3}{*}{ Gender } & \multirow{3}{*}{$\begin{array}{c}\text { Mann- } \\
\text { Whitney } \\
\text { Test }\end{array}$} & Academic & $\begin{array}{c}\text { Female } \\
\text { Male }\end{array}$ & $\begin{array}{r}168.69 \\
113.04 \\
\end{array}$ & 0.00 & $\begin{array}{c}\text { Different } \\
(\mathbf{p}<0.05)\end{array}$ \\
\hline & & Social & $\begin{array}{c}\text { Female } \\
\text { Male }\end{array}$ & $\begin{array}{l}168.41 \\
113.88 \\
\end{array}$ & 0.00 & $\begin{array}{c}\text { Different } \\
(p<0.05)\end{array}$ \\
\hline & & $\begin{array}{c}\text { Self- } \\
\text { Presentation }\end{array}$ & $\begin{array}{c}\text { Female } \\
\text { Male }\end{array}$ & $\begin{array}{l}167.14 \\
117.77\end{array}$ & 0.00 & $\begin{array}{c}\text { Different } \\
(p<0.05)\end{array}$ \\
\hline
\end{tabular}

In this study, participants' approach to their academic self-concepts $(0.00$, $\mathrm{p}<0.05)$, social self-concepts $(0.00, \mathrm{p}<0.05)$, and self-presentations $(0.00, \mathrm{p}<0.05)$ become different according to the gender variable as seen in Table 15.

H9. There is a difference between the year of birth and the subscales (the academic self-concept, the social self-concept, and the self-presentation). 
Table 16. Differences between Year of Birth and the Subscales

\begin{tabular}{|c|c|c|c|c|c|c|}
\hline Variable & Test & Dimensions & Groups & $\begin{array}{l}\text { Mean } \\
\text { Rank }\end{array}$ & $\mathbf{P}$ & Comment \\
\hline \multirow{3}{*}{$\begin{array}{l}\text { Year of } \\
\text { Birth }\end{array}$} & \multirow{3}{*}{$\begin{array}{c}\text { Kruskal } \\
\text { Wallis Test }\end{array}$} & Academic & $\begin{array}{l}1980-1986 \\
1987-1993 \\
1994-2000\end{array}$ & $\begin{array}{l}180.64 \\
152.05 \\
150.72\end{array}$ & 0.15 & $\begin{array}{l}\text { Not Different } \\
\quad(\mathbf{p}>\mathbf{0 . 0 5})\end{array}$ \\
\hline & & Social & $\begin{array}{l}1980-1986 \\
1987-1993 \\
1994-2000\end{array}$ & $\begin{array}{l}176.29 \\
151.55 \\
151.99\end{array}$ & 0.27 & $\begin{array}{l}\text { Not Different } \\
\quad(\mathbf{p}>\mathbf{0 . 0 5})\end{array}$ \\
\hline & & $\begin{array}{c}\text { Self- } \\
\text { Presentation }\end{array}$ & $\begin{array}{l}1980-1986 \\
1987-1993 \\
1994-2000\end{array}$ & $\begin{array}{l}188.90 \\
156.81 \\
146.22\end{array}$ & 0.02 & $\begin{array}{c}\text { Different } \\
(p<0.05)\end{array}$ \\
\hline
\end{tabular}

The results of the analysis as seen in Table 16 shows that there is not a difference between the year of birth and academic $(0.15, \mathrm{p}>0.05)$ or social $(0.27$, $\mathrm{p}>0.05)$ self-concepts: however, there is a difference between the year of birth and self-presentation $(0.02, \mathrm{p}<0.05)$. That's why the Mann-Whitney Test was applied in pairs to reveal which groups are different from the others.

Table 17. Self-Presentation Post-Hoc

\begin{tabular}{|c|c|c|c|c|c|c|}
\hline Variable & Test & Dimensions & Groups & $\begin{array}{l}\text { Mean } \\
\text { Rank }\end{array}$ & $\mathbf{P}$ & Comment \\
\hline \multirow{3}{*}{$\begin{array}{l}\text { Year of } \\
\text { Birth }\end{array}$} & \multirow{3}{*}{$\begin{array}{c}\text { Mann- } \\
\text { Whitney } \\
\text { Test }\end{array}$} & Group 1 & $\begin{array}{l}1980-1986 \\
1987-1993\end{array}$ & $\begin{array}{l}168.69 \\
113.04\end{array}$ & 0.05 & $\begin{array}{c}\text { Not } \\
\text { Different } \\
(\mathbf{p}>0.05)\end{array}$ \\
\hline & & Group 2 & $\begin{array}{l}1980-1986 \\
1994-2000\end{array}$ & $\begin{array}{l}168.41 \\
113.88\end{array}$ & 0.00 & $\begin{array}{c}\text { Different } \\
(\mathbf{p}<\mathbf{0 . 0 5})\end{array}$ \\
\hline & & Group 3 & $\begin{array}{l}1987-1993 \\
1994-2000\end{array}$ & $\begin{array}{l}167.14 \\
117.77\end{array}$ & 0.035 & $\begin{array}{c}\text { Not } \\
\text { Different } \\
(\mathbf{p}>\mathbf{0 . 0 5})\end{array}$ \\
\hline
\end{tabular}

In Table 17, the results reveal that the participants in this questionnaire show a difference in their self-presentation according to their year of birth, between 1980 1986 and 1994-2000. The mean ranks belonging to the participants born between 1980-1986 are greater than the ones in 1994-2000.

\section{Discussion \& Conclusion}

Individuals represent several aspects of themselves to other users on social media platforms. Even though there are some kinds of missing points like nonverbal communication opportunities, it is obvious that every social media user makes use of the available communicative actions to represent themselves and to build an impression on the other individuals they are in contact with. Individuals create their own social lives and environments within the social media platforms, and this kind of a relationship with the others urges them to create another social identity. 
This social identity on social media platforms consists of frames like social interest, inferiority feeling, and superiority feeling as mentioned in Adler's individual psychology theory. Before having social media use in everyday lives, individuals used to interact with the others at schools, at home, or during an event in which they participated. Just after having the opportunity to interact on the Internet, even newborn babies are inescapably involved in the digital world with the help of their caregivers. That's why individuals have started searching for their social interests in digital platforms, and they had the possibility to experience different feelings because of having more than the physical environment. In addition to this, individuals construct their social identities by getting in touch with the others on any platform: however, constructing an identity is not completed only and solely. Because identities are only defined when they interact with the other identities, social identities on social media platforms can also be perceived by the other user as their own self-concept regarding real self and ideal selfchanges.

This interaction and perception are all about the individuals' selves and the platform itself because the perceptions and presentations can be affected according to the communicative affordances which users have got. In this sense, Goffman's ideas are incredibly valid for today's contemporary communication platforms and identity construction. Because social identities discussed by Adler and Erikson depend on the social behaviors and contexts, these behaviors and contexts on social media might be analyzed by focusing on the current and instant situations and also audiences. The reality of performativity was started being re-discussed with the ideas of Butler to understand and analyze the mobility and subjectivity. By getting all these ideas on the personalities and the environments, Instagram is one of the social media platforms, which gives clues to understand how profile information, pictures, videos, and captions can pave the way for the individuals to affect the others and represent themselves.

In this study, the data collected from generation-y Instagram users basically shows that communicative actions provided by Instagram are used in different perspectives: however, mostly generation-y users share posts, highlight their stories and watch the IGTV. When these three communicative actions are thought, the usage habits of generation-y users are based on stable actions like remaining posts and fixed stories. In addition to this, watching the IGTV can give other clues on behalf of generation-y users who look for something ephemeral and concise, but not brief and to the point. Based on their priorities and personal reasons, generation-y users share their achievements, their own photos, photos with their friends, and their activities or travels: with the help of such sharings, they become active in the platform to be able to follow their connections and explore new ideas. Apart from photos sharing, Instagram as a social media platform allows its users to share some other content types like texts, but generation-y users are basically there for visual content. In addition to these results based on Instagram usage habits, the Ideal and Real Self-Concept Scale was used in this study.

The Ideal and Real Self-Concept Scale consists of three subscales like the academic self-concept, social self-concept, and self-presentation to reveal the real and ideal selves in forms of their talents, perceptions of success, trust in success, 
friendships, family relations, and their insights about themselves. Based on the academic-self-concept, the participants do not mostly feel good, satisfied, happy about their academic works, and do not feel involved in academic life with their achievements. In addition to this, they are even not in perceiving the other individuals by comparing themselves with the others in the same classes or at the same university. For the social self-concept, all the participants reflect on positive feelings, experiences, and interactions with their friends and family members. The participants do not feel attractive, and they think that they are not mostly of good physical body appearance. They also reflect their own ideas about themselves by showing a positive role in their self-presentation. When these three subscales are considered, the correlation analysis reveals that there is a positive relationship between academic self-concept, social self-concept, and self-presentation. The social identity and feeling about themselves and their environments are coherently structured and the self-reported perceptions of their feelings allow us to see how the real and ideal selves are put closer.

Reflecting on Goffman's ideas on identity and self-presentation and Butler's performativity, it is obviously seen that intersectionality regarding the mobility of the environment in which we try to construct our own identities depends on the communicative actions we are able to show. All the individuals create their selfdescriptive profiles to be involved within a network, and these profiles depend on the type of social media platforms because each of them has different back stages to become a member, various front stages to allow users to act accordingly, most importantly millions of audience can be reached easily with whatever provided. In the context of Instagram, most self-presentations focus on users' friends and the networks they are in. A certain degree of visibility based on stable and ephemeral posts to facilitate different extensions of self in the absence of materials. However, individuals make use of the platforms with their own demographic features and their knowledge on "how-to-make-use-of" with the experience they have got. Such distinct ideas give a chance to focus on the hybridity of social identities on social media platforms because the users have a physical response and correspondence.

Being female or male evolves into a kind of self-concept. That's why the first insight which was examined in this study was about whether there is any relationship between gender and the self-concept types and what direction it was. The results show that there is a negative-directed relationship between gender and the participants' self-conceptualization regarding their academic, social, and personal background. This relationship is weak in strength with respect to academic self-concept, social self-concept, and self-presentation of generation-y Instagram users in Turkey. Circumstantially, the year of birth means a lot in such studies. Although generation-y is in the heart of this study, there are years between the first and the last members of this generation and the years portray different periods in sociological studies. That's why whether there is any relationship between the year of birth of participants and self-conceptualization was also examined through academic self-concept, social self-concept, and self-presentation. The result shows that there is no meaningful relationship between year of birth and academic self-concept or social self-concept, but not self-presentation even though the strength is very weak. In addition to this relationship tests, the tests of 
differences regarding demographic features reveal that the self-concepts in this study become different according to gender variable, and academic self-concept and social self-concept do not show any difference according to the year of birth, but only self-presentation.

Self-concept is also affected by the uses of communicative actions in addition to the demographic features of individuals. The frequency of post sharing refers to how much the individuals are in connection with the others: in other words, how much individuals' self-conceptualization meets others on social media platforms. Despite having no relationship between the frequency of post sharing and academic self-concept, there is a relationship between post sharing frequency and social self-concept or self-presentation. Under any circumstances, the frequency relation is very weak in strength. Posting is not the only action users can do on Instagram, but spending time by scrolling down and up or watching ephemeral stories and the IGTV refer to another interaction by consuming the content itself. Because the role of prosumer has both roles for producing and/or consuming, time spent on Instagram daily means a lot for the individuals to reflect their selves. On this wise, the results as expected reveal there is a relationship between selfconcepts and the time which individuals spend on Instagram. The relationship is very weak, but indicates that both variables intend to go up in response to one another. However, a longitudinal use and personal reasons do not matter for presenting selves on Instagram. Such results shed light on the importance which individuals should place on their social media uses and efforts to represent themselves under any circumstances.

Consequently, how multiple selves interact to inform others through social media platforms can be divided into subsections and be different even within a generation. Due to the virtual nature of Instagram as a comprehensive platform for networking and constructing identities in different senses, generation-y users hold the opportunities to a wider range of relationships and acquaintances. For analyzing real or ideal selves and deciding how to create academic self-concept, social self-concept, and self-presentation on Instagram, generation-y Instagram users both blend and conflict in different senses to bridge their selves and their identities. Both the real and ideal selves blend two identities to construct another social identity on social media platforms, and generation-y Instagram users as limited to our participants use a mixture regarding their own subjectivity while the roles, interaction areas, and audience cooperate and collide, so do the real and ideal selves.

\section{Ethical Declaration}

In the writing process of the study titled "Shared Selves on Social Media: Examining the Relationship between Real and Ideal Selves of Generation-Y Instagram Users in Turkey," the scientific, ethical and the citation rules were observed; there was not made any falsification on the collected data and this study was not sent to any other academic media for evaluation. 


\section{Bibliography}

Akbulut, Y. (2010). Sosyal bilimlerde SPSS uygulamalart. (SPSS applications in social sciences). İstanbul: İdeal Kültür Yayıncilık.

Barker, C. (1999). Television, globalization and cultural identities. Buckingham: Open University Press.

Baş, T. (2013). Anket: anket nasıl hazırlanır?, Anket nasıl uygulanır?, Anket nasıl değerlendirilir? (Questionnaire: how to prepare? How to apply? How to analyze?) Ankara: Seçkin Yayıncılık.

Boyd, D. M., Ellison, N. B. (2007). Social network sites: definition, history, and scholarship. Journal of Computer-Mediated Communication, 13(1), 210-230.

Can, A. (2014). SPSS ile bilimsel araştırma sürecinde nicel veri analizi. (Quantitative data analysis in the process of academic research with SPSS). Ankara: Pegem Akademi.

Çapri, B. (2019). Birey merkezli terapi. (Person-centered therapy). In Z. Karataş, Y. Yavuzer (Eds.), Psikolojik danışma ve psikoterapi kuramları (Psychological counseling and psychotherapy theories) (2nd Ed., pp. 127-160). Ankara: Pegem Akademi.

Çetinkaya-Yıldız, E., Gençtanırım-Kurt, D. (2019). İnsancıl kuram. (Humanist theory). In D. Gençtanırım-Kurt, E. Çetinkaya-Yıılız (Eds.), Kişilik kuramları. (Personality theories) (4th Ed., pp. 436-483). Ankara: Pegem Akademi.

Donath, J., Boyd, D. (2004). Public displays of connection. BT Technology Journal, 22(4), $71-82$.

Ellis, A., Abrams, L. D., Abrams, M. (2009). Personality theories: critical perspectives. Los Angeles: Sage Publications.

Erikson, E. (1959). Identity and the life cycle. New York: International Universities Press.

Gregson, N., Rose, G. (2000). Taking Butler elsewhere: performativities, spatialities and subjectivities. Environment and Planning D: Society and Space, 18(4), 433-452.

Hatipoğlu Sümer, Z. (2019). Bireysel terapi. (Individual therapy). In Z. Karataş, Y. Yavuzer (Eds.), Psikolojik danışma ve psikoterapi kuramları. (Psychological counseling and psychotherapy theories) (2nd Ed., pp. 91-126). Ankara: Pegem Akademi.

Hogan, B. (2010). The presentation of self in the age of social media: distinguishing performances and exhibitions online. Bulletin of Science, Technology, \& Society, 30(6), 377-386.

Hootsuite \& We Are Social (2020). Digital 2020 global digital overview. Retrieved from: https://wearesocial.com/blog/2020/01/digital-2020-3-8-billion-people-use-socialmedia.

Indaco, A., Manovich, L. (2016). Urban social media inequality: definition, measurements, and application. Arxiv.org. Retrieved from: https://arxiv.org/ftp/arxiv/papers/1607/ 1607.01845.pdf.

Kapıkıran, N. A. (2004). İdeal ve gerçek benlik kavramı ölçeğinin güvenirliği. (Reliability and validity of ideal and real self-concept scale). Pamukkale Üniversitesi Ë̆itim Fakuiltesi Dergisi/Pamukkale University Journal of Education, 16(16), 14-25.

Karairmak, Ö., Aydoğan, D. (2019). Bireysel psikoloji. (Individual psychology). In D. Gençtanıım-Kurt, E. Çetinkaya-Yıldız (Eds.), Kişilik kuramları. (Personality theories) (4th Ed., pp. 150-191). Ankara: Pegem Akademi.

Lenhart, A. (2015). Teens, social media \& technology overview 2015. Retrieved from: https://www.pewresearch.org/internet/2015/04/09/teens-social-media-technology2015/. 
Litt, E. (2012). Knock, knock. Who's there? The imagined audience. Journal of Broadcasting and Electronic Media, 56(3), 330-345.

Maccoby, E. E. (1980). Social development: psychological growth and the parent-child relationship. New York, NY: Harcourt Brace Jovanovich.

Manovich, L. (2001). The language of new media. MIT Press.

Marwick, A., Boyd, D. (2011). I tweet honestly, I tweet passionately: twitter users, context collapse, and the imagined audience. New Media \& Society, 13(1), 114-133.

McLuhan M. (1962). The Gutenberg galaxy: the making of typographic man. Toronto: University of Toronto Press.

Neill, J. (2005). Definitions of various self-constructs: self-esteem, self-efficacy, selfconfidence \& self-concept. Wilderdom.

Papacharissi, Z. (2002). The presentation of self in virtual life: characteristics of personal home pages. Journalism and Mass Communication Quarterly, 79(3), 643-660.

Prensky, M. (2001). Digital natives, digital immigrants part 1. On the Horizon, 9(5), 1-6.

Sakamoto, R. (1996). Japan, hybridity and the creation of colonialist discourse. Theory, Culture and Society, 13(3), 113-128.

Steinberg, L., Morris, A. S. (2001). Adolescent development. Annual Review of Psychology, $52(\mathrm{Feb}), 83-110$.

Van Dijk, J. (2006). The network society: social aspects of new media (2nd Ed.). London: Sage Publications.

Waugh, R. F. (2001). Measuring ideal and real self-concept on the same scale, based on a multifaceted, hierarchical model of self-concept. Educational and Psychological Measurement, 61(1), 85-101. 



\title{
The Role of Radio in Setting the Agenda for the Electorate and Creating an Atmosphere of Aggression during Elections in the Northern Region of Ghana
}

\author{
By Muhammed Abdulai ${ }^{*}$ Hadi Ibrahim ${ }^{ \pm}$\& \\ Mohammed Adams Mashoudt
}

\begin{abstract}
This study uses a qualitative approach to examine the role of radio in setting the agenda for the electorate and creating an atmosphere of aggression during elections in the Northern Region of Ghana. Fifteen research participants, made up of seven active listeners and eight reporters, editors, and radio presenters were engaged in conversation analysis and generated data for the study. The study revealed that radio plays a vital role in setting the agenda for the electorate before, during, and after elections in Ghana; this is done by using radio as a channel of communication to send messages of peace. The study also cast light on how radio uses music and entertainment to educate its audiences with messages of tolerance and free, fair and transparent elections. In view of these findings, the study strongly recommends that media practitioners and journalists be trained in media professionalism, focusing on what and how to report during election time in Ghana.
\end{abstract}

Keywords: Media, Elections, Education, Peace, Ghana

\section{Introduction}

Fundamentally, elections are considered to be credible only when the primary principles of democracy are found to inform the processes. Embedded in these principles is the enabling environment that engenders the inalienable right to free discussions and the expression of divergent opinions on issues and public policies deemed to be political by both the political actors and the electorate. This calls for substantial and significant access to an independent, open, and diverse media that exercises civil responsibility by generating balance and impartial information for voters and candidates alike (United Nations Development Programme, UNDP, 2014). The UNDP (2014:1) expressly puts forward the sacred role of the media when it states that "the media has a unique position as both a conveyor and a recipient of information".

In Ghana, the media is regarded as a serious and major stakeholder as well as

\footnotetext{
"Lecturer, Tallinn University, School of Governance, Law and Society, Estonia \& University for Development Studies, Faculty of Communication and Cultural Studies, Department of Communication, Innovation and Technology, Ghana.

${ }^{ \pm}$Commercial Officer, Regional Offices and Foreign Missions, Ministry of Trade and Industry, Sunyani, Ghana.

'Lecturer, University for Development Studies, Faculty of Communication and Cultural Studies, Department of Communication, Innovation and Technology, Ghana.
} 
the fourth realm of the state, which is an essential cornerstone of this fledgling democracy. The media draws its fundamental mandate from Ghana's 1992 operating constitution, which seeks to constantly develop an efficient, vibrant, and powerful media that ensures checks and balances on the other arms of government. The expectation is that the media should keep the electorate well informed both in terms of the election process and the policies of those seeking the mandate of the electorate. For instance, while television is the medium most used by politicians in the developed countries, radio is predominantly used in many developing countries (Myers 2008; Zhou et al. 2016; Kioko Ireri et al. 2017).

Generally, the media enjoys certain fundamental freedoms, the exercise of which contributes to the good of society by way of education, balance reportage, and entertainment, among other factors. However, the functions of the media during elections are more of a conundrum in most parts of the African continent, and are seen in how the media acts as a proxy in the battle between rival political groups sowing seeds of discord, divisiveness and hate speech instead of engendering consensus, sober debate and trust among the people (Shiela 2013). The myths surrounding this perceived conundrum remain to be demystified by conscious and well-intended academic endeavor. It must be pointed out that scholars and well-meaning institutions have extensively investigated and explored the relationship between election violence and peaceful elections and development (Mikinda 1996; Matu Ngui 2009; Joey 2012; FOSDA 2015; Adebayo 2016). However, in the case of the relationship between the radio and elections, existing studies tend to focus on other countries in Sub-Saharan Africa and on other areas of Ghana (IMPACS 2004; Owusu 2012; Shiela 2013; UNDP 2014; Yankem 2015).

For instance, through a quantitative study, Yankem (2015) explored the role of radio as a tool for political mobilization in Kenya during the 2013 general elections, with a focus on Nairobi. The study revealed that about $76 \%$ of the electorate who listened to the radio during these elections were exposed to political content through talk shows, news and advertisements. While these research bodies (IMPACTS 2004; Owusu 2012; Shiela 2013; UNDP 2014; Yankem 2015) present an excellent overview of the relationship between the media, elections, election violence, and development in Sub-Saharan Africa, there is paucity of studies on the role of radio in setting the agenda for the electorate and creating an atmosphere of aggression during elections in the Northern Region of Ghana. Therefore, the intriguing question of how radio, as a significant element of the media, plays a role during elections in this part of Ghana persists and begs scrutiny and interrogation. This study therefore, seeks specifically to answer the question: What is the role of radio in setting the agenda for the electorate and creating an atmosphere of aggression during elections in the Northern Region of Ghana?

This study is important because election periods are among the most volatile across the globe, and the use of radio during elections continues in most African countries. The study considers radio as a mass media communication tool because it is the most used medium of communication for political mobilization, ideological and policy propagation in Ghana throughout the election period. In addition, radio is far more affordable and accessible, and broadcasts are often made in local languages that people can understand. The study has chosen the 
election period because in most cases, countries in Sub-Saharan Africa and other developing countries are characterized with violence and an aggressive atmosphere, especially during this period. We define an aggressive election atmosphere as a condition in an election period which has the potential to trigger violence and/or conflict. In the context of Ghana, some municipalities are identified as "hot spots"1 during elections. In light of this, editors, reporters, and radio presenters make choices about what to report and how to report it, thereby setting the agenda for the electorate and creating an aggressive atmosphere. This study will contribute to the existing literature on media studies because the approach to identifying the specific role of radio during elections in the Northern Region of Ghana is likely to provide rich perspectives and make an important contribution to research on media professionalism in Africa.

The study employs the nominalist paradigm, a qualitative case research design, and conversation analysis with reporters, editors, radio presenters, and active listeners in three municipalities in the Northern Region of Ghana. The paper is structured as follows: review of the literature and theoretical underpinnings, research methodology, discussion, and conclusion.

\section{Conceptualizing the Role of Media in Elections}

According to Odhiambo (2017), the media plays a vital role at the time of elections, and it does that by informing the electorate and playing a watch dog role. Conversely, media and journalists are also seen to be acting contrary to journalistic ethics by indulging in demeanors that tend to fuel election-related violence through their reportage. It is, therefore, imperative to interrogate the role of the media during elections because violence associated with elections have increasingly bedeviled world leaders especially in many parts of Africa. For instance, hate speech and poor reportage chained out by the media resulted in inflamed passions and tensions and led to attacks and reprisal attacks with a radio presenter hauled before the international criminal courts as evidenced in Kenya (Odhiambo 2017; Iriri et al. 2017). It is observed that "elections correspond to periods of heightened media coverage and reporting with each political party wanting to lead the country, these transitional times are brought with competitive language, rising tensions, and occasional political violence, sometimes even resulting in violent conflict" (Caput 2011:3). This implies that the role of media in furthering the course of elections can make and unmake the electoral process. Therefore, the players and stakeholders in the media fraternity and elections alike have some fundamental and civil responsibilities, the exercise of which is likely to bring good outcomes during election periods.

In addition, several authors in media and elections have noted that election periods are often fragile particularly in Africa (Hoglund 2009; Joey 2012; Adebayo 2016). In light of this, Matu Ngui (2009) recommends that during elections, media players like journalists, and news presenters be trained in media professionalism,

\footnotetext{
${ }^{1}$ Hot spots: In the Ghanaian context, "hot spots" are electoral areas where a little misunderstanding or misinformation could lead to violent behavior by the electorate.
} 
imbued with mind-sets that are conflict preventive, and to eschew reportage that incites divisiveness, antagonism, and has the tendency of resulting in violence that jeopardizes social cohesion and order. Similarly, Caput (2011: 4) noted that in order to achieve efficient and impartial coverage on elections matters, journalists ought to acquire basic skills and knowledge on relevant legal documents and much more be well educated "on the different institutions involved in the organization of elections such as; campaigns rules and regulations, the format of the ballot papers, and the procedures for the announcement of the results".

Furthermore, Windeck (2010) is of the view that the interdependence between the media and the political systems are manifestly apparent. In the interdependence lies an obvious trade off inherent in the systems where information that emanates from the political systems is exchanged for coverage in the media outlets. Thus, the media relies on the political systems for the supply of relevant information, while at the same time, the political systems count on the media systems to have the information efficiently and effectively conveyed to the electorate (Jarren and Donges 2006). Moreover, Joey (2012) noted that the media is located at the second corner of the triangle in political communication with a traditional task of transmitting information from the political actors to the electorate. So, they intermediate between the political players and the messages they generate for the electorate by assisting them comprehend the information as ultimate recipients. Aside the mediating role, the media undertakes independent communication in the form of running political commentary, editorials and/or interviews. This mediation role is often hampered by the forces of incumbent parties as Shiela (2013) observed that the media in new and restored democracy do not always live up to the ideal. They are hobbled by stringent laws, monopolistic ownership, and sometimes, the threat of brute force. Again, intrinsic values are also placed on the postulation that the role of the media in elections are influential and deterministic in nature. By the watchdog role of the media, couple with its powers to provide the platform that informs and keeps the electorate abreast with electoral issues, as well as the influence it wields, the media end up setting the agenda for issues, the candidates' positions and the reasons for voting (UNDP 2014).

\section{The Agenda setting Function of Traditional Media}

This study adopts the agenda setting theory to cast light on the role of radio in setting the agenda for the electorate and creating an atmosphere of aggression during elections in the Northern Region of Ghana. Agenda setting theory is a prominent concept in communication studies that describes the enormous influence of the media in determining the issues the public think about and the extent of salience attached to issues in a nation (Ireri et al. 2017). The theory has a basic tenet that the media may not be successful in determining what we think, but it has an influence on the matters we think about, and how we think about them. It was in this view that Shaw and Martin (1992) observed that the media do not tell us what issues to believe, but suggests issues that people collectively may agree to discuss and probably act on it. The agenda-setting theory was conceptualized by 
Maxwell McCombs and Donald Shaw (1972) to understand the influence of media in shaping people's voting patterns in the 1968 U.S presidential election. However, in the past decades, scholars have applied the concept of agenda setting effects in diverse fields such as communication studies, politics, healthcare, family health, civil rights and business (Zhou et al. 2016). The agenda setting concept is made up of three interconnected aspects -media agenda, public agenda and policy agenda (Shaw and Martin 1992). Media agenda are the issues discussed or covered by media reportage, and public agenda are issues audience members consider salient. The media agenda largely influence matters on the public agenda because they attach prominence to issues on the public agenda (McCombs and Shaw 1972). The three are interrelated, and when an agenda setting process is initiated, they interact and influence each other. Media agenda and public agenda settings are common in the communication research, but policy agenda is usually researched by scholars in the field of political science and sociology (Zhou et al. 2016).

Agenda setting theory operates at three levels: The first level, second level and third level agenda setting (Miller 2005: 270). The first level agenda setting espouses on how people's views about matters are considered salient in a given nation, and determined by the prominence and space of such issues in media coverage (Ireri et al. 2017). Likewise, the second level agenda setting shades light on how media lay emphasis on particular attributes while covering stories, hence directing the focus of audience members towards those features in news reportage in particular tone or affective feelings -negative, positive or neutral of the subject (Zhou et al. 2016; Littau and Stewart 2015). So, by attaching saliences and emphasizing certain characteristics of the issues in their coverage, the media affects what people regards as importance to form an opinion about (Zhou et al. 2016). The third level agenda setting posits that media is not only able to inform what we think about and how we think about issues, but informs us what and how to associate, with salience of interrelationships among issues and attributes that can move between agendas simultaneously (Vu Guo and McCombs 2014; McCombs et al. 2014). In this regard, the study is located within the second level agenda setting to explore how the radio lays emphasis on certain issues as salient, and setting the agenda for the electorate and creating an atmosphere of aggression during elections in the Northern Region of Ghana.

As stated earlier, the agenda setting theory was originally conducted to explore the influence of media in shaping people's voting patterns in the U.S. However, the political factors and media systems in Ghana differ greatly from those in the U.S. As such, some of the assumptions of the agenda setting theory may not operate exactly the same in the context of Ghana (Yeojin et al. 2016). Notwithstanding, the theory is still relevant for this study because the Ghanaian electorate depend on the media messages for information and the media also depends on the environment for information. Therefore, the watchdog role of the media over the society, and couple with its powers to inform and educate the public with electoral issues, the media end up setting agenda for either peaceful or an atmosphere of aggression during election in Ghana. In light of this, the agenda setting effect of the media is capable of shaping the behavior and attitudes of people (Shaw and Martin 1992). Media reportage during election period has great impact on the 
attitudes of the Ghanaian electorate because the media serves as a conduit where most electorate access information. In this vein, the agenda setting concept will provide a strong conceptual foundation to analyze the role of radio in setting the agenda for the electorate and creating an atmosphere of aggression during elections in the Northern Region of Ghana.

\section{Research Design and Method}

This study is located within the nominalist paradigm. The nominalist approach assumes that reality is constructed by individuals in interaction with each other (Bryman 2004; Creswell 2009; Kuada 2012). It further noted that there are multiple and subjective realities. In view of this, reality about the role of radio in setting the agenda for the electorate and creating an atmosphere of aggression during elections in the Northern Region of Ghana could be constructed through the interactions of journalists, radio presenters, reporters and their audiences, and as well as, the interactions of the audiences with the messages disseminated via the radio stations. Similarly, the study adopts a qualitative case study design. The qualitative case study design is focused on an explanatory, exploratory and descriptive interrogation of the phenomenon (Yin 2003). As a result, the study has employed an explanatory and descriptive investigation into the role of radio in setting the agenda for the electorate and creating an atmosphere of aggression during elections in the Northern Region of Ghana. The case study approach was adopted because it offers the researchers the opportunity to engage with the participants within their real-life context, and restricted the researchers from having any control over the events in the setting of the participants (Yin 2003). The purposive sampling techniques was used for the study. This sampling technique allows for the deliberate selection of respondents whose responses are likely to generate useful data for the study (Leedy and Ormrod 2005). In all, fifteen media practitioners, reporters, editors, and active listeners to the radio stations selected were engaged in conversation analysis. The number of study subjects who were represented in the study are illustrated in the table 1 .

\section{Research Setting and Data Sources}

Ghana has 16 administrative regions, five of which are located in the Northern Savannah Ecological Zone. These five regions are: Upper West, Upper East, Northern, North East and Savanna regions (Ghana Statistical Service 2010). The study was carried out in the Northern Region. The study adopts conversational analysis technique as a tool for data generation. Bryman (2004: 365) defines conversation analysis as the "analysis of talks/conversations as it occurs in natural situations". 
Table 1. Respondents Profile

\begin{tabular}{|l|c|c|c|}
\hline $\begin{array}{l}\text { Codes of } \\
\text { Study subjects }\end{array}$ & $\begin{array}{c}\text { Radio Stations of the study } \\
\text { subjects/Listeners }\end{array}$ & Sex & Responsibility \\
\hline 1.ZR & Zaa Radio-99.3 & $\mathrm{M}$ & Editor \\
\hline 2. RS & Radio Savannah-91.2 & $\mathrm{F}$ & Reporter \\
\hline 3. MT & Might FM-90.5 & $\mathrm{F}$ & Radio presenter \\
\hline 4. EG & Eagle FM-94.1 & $\mathrm{M}$ & Radio presenter \\
\hline 5. GM & Gmantambo Radio-96.1 & $\mathrm{M}$ & Radio presenter \\
\hline 6.NS & Northstar Radio-92.2 & $\mathrm{M}$ & Reporter \\
\hline 7.BR & Bishara Radio-97.7 & $\mathrm{M}$ & Editor \\
\hline 8.KS & Kesmi FM 107.1 & $\mathrm{F}$ & Radio presenter \\
\hline 9.LL & Active listener & $\mathrm{M}$ & Active listener \\
\hline 10.LP & Active listener & $\mathrm{F}$ & Active listener \\
\hline 11.LC & Active listener & $\mathrm{F}$ & Active listener \\
\hline 12.LY & Active listener & $\mathrm{M}$ & Active listener \\
\hline 13.LU & Active listener & $\mathrm{M}$ & Active listener \\
\hline 14.LW & Active listener & $\mathrm{M}$ & Active listener \\
\hline 15.LM & Active listener & $\mathrm{F}$ & Active listener \\
\hline
\end{tabular}

In other words, conversation analysis is considered as a form of data collection technique that involves conducting conversations with small respondents to explore their perspectives on a particular idea, program, subject or situation (Creswell 2009). At the start of the study, all the stakeholders were identified and fifteen editors, reporters, radio presenters, and active listeners were selected and used for detailed and comprehensive data collection. The active listeners and other participants were selected to solicit their views on the agenda setting function of radio, during elections in the Northern Region of Ghana.

We selected the study participants who were willing to provide information by virtue of their knowledge and experience on the role of radio in setting the agenda for the electorate and creating an atmosphere of aggression during elections, and excluded those who had inadequate knowledge and experience on the role of radio in setting the agenda for the electorate and creating an atmosphere of aggression during elections. After the identification and selection of the participants, we had long conversations with all the participants. Each talk/ conversation lasted for about 1 hour and 30 minutes, and the conversations were conducted face-to-face with each participant on different days in the month of October 2018. Some of the questions posed to the study participants are outlined as follows: describe to me how the radio is used to ensure peaceful election in Ghana. Tell me how we can prevent the use of indecent languages on the radio during and after elections. Do you have code of ethics on how and what to report during election time in Ghana? How are these codes of ethics enforced? All the conversations were audiotaped and transcribed afterwards. This technique of data collection was used because we wanted detailed information about how radio is used in setting the agenda for the electorate and creating an atmosphere of aggression during elections in the Northern Region of Ghana. 
In terms of data analysis, the thematic analysis technique was used to analyze and identify the main themes in the study. Thereafter, the open coding system was applied and coded the data, and identified the common strand of themes. Again, the axial coding was used to establish relationship between themes (Saldaña 2013). After coding the data, we grouped them into themes according to their similarities. Classical content analysis was used aftere the themes were generated with their respective sub-themes. Classical content analysis is similar to constant comparison analysis (Abdulai et al. 2017). The number of times each descriptive code occurred was ranked and the most important concepts were identified as the themes. In connection with data interpretation, the hermeneutic approach was used. The meaning interpretation perspective focused on conducting a very close detailed reading of texts. This is done to acquire a profound deep understanding of the texts to discover deeper meanings that are embedded within the texts (Neuman 2014).In a similar vein, we conducted a detailed readings of the entire data and discovered the deeper meanings explicitly found in the research subjects responses.

In order to ensure the trustworthiness of the findings, the member crosschecking approach was applied where the transcribed data was presented back to four of the radio presenters and reporters, and they assessed the extent to which the data represented their perspectives as recorded. Again, informed consent preceded participation, and the application of inclusion and exclusion criteria for participant selection (Marshall 2003).

\section{Findings and Discussion}

This part of the study is a presentation of the research findings, and discussion on the role of radio in setting the agenda for the electorate and creating an atmosphere of aggression during elections in the Northern Region of Ghana. Two themes have been discussed: radio, agenda setting and atmosphere of aggression during elections, and the role of radio in electoral education.

\section{Radio, Agenda setting and Atmosphere of Aggression during Elections}

Given that the society depends on the media for information during elections to make informed decisions, and given that the media sets the agenda for the electorate on issues they consider salient during elections make it expedient to shed light on how the media is used to set agenda for hate and aggression in a developing country context. In view of the dependency relationship between the media and the society, one of the research participants, a radio presenter was asked to explain how the radio sets its agenda during elections in Ghana. In response, the participant expressed:

"The radio serves as a channel through which elite's set their agenda,... eeh... they see the media as a powerful resource and use it to influence electorate, mobilize electorate, and to win and consolidate political power" (4-EG). 
From the words of the research participant, it implies that the radio is a powerful tool which can be used to capture the attention of the electorate by elites in society, mobilize the electorate, capture and maintained political power. In addition, the expression provides a more nuanced understanding of agenda-setting effects on the end users of traditional mass communication channels (Zhou et al. 2016), and further enriches our understanding of Lippmann's (1922) metaphor that the news media construct a pseudo-environment for the mediated end users. This implies that the radio and other traditional mass communication channels which most end users trust as "authentic messengers" in most cases creates false content for the mediated end users because the environment where the media practitioners access their information is too complex for direct experience (Lippman 1922). Besides, most end users do not critically check the content produced via radio and other traditional mass communication channels. Relating the theoretical basis to the submission of the participant, it means that the information the Ghanaian electorate' access via the radio and other mass communication channels before and during elections are too complex, and are often generated by people with selfseeking interests.

In connection with the same issue, one of the research participants, a news reporter asserts:

"we are public radio station, so, our agenda is set by the national policy. For instance, if we want to have a credible election, our policy should be aimed towards ensuring peaceful eerh...elections through dissemination of messages of peace and peace education (2-RS).

The views expressed by the research participant resonate with the mutual relationship between the media, public and policy agenda setting perspectives. In this regard, the media agenda is the set of issues addressed by media sources, and the public agenda are issues the public considers as salient (Shaw and Martin 1992). Therefore, both Ghanaian public and private radio stations could influence the public agenda before, during and after elections. On one hand, media personnel can decide to act responsibly by disseminating information that is unbiased and devoid of unnecessary hype that is designed to promote peace during elections. On the other hand, media practitioners can also decide to disseminate false or unsubstantiated information during elections to create an atmosphere of aggression and violence. The revelation above is in line with the findings of Iriri et al. (2017) that current reportage by media personnel in Africa during elections is mainly motivated by factors such as ownership, geopolitical location and religious/ethnic inclination. As a result, the immense influence of the media requires that media personnel are professionally trained to report social-political issues in a conflictsensitive and responsible manner before, during and after elections in Ghana.

Moreover, as part of the media role in elections, it creates a platform for politicians to sell out their policies to the electorate in order to canvass for votes. It also allows citizens to criticise the policies of various political parties in order to promote participatory democracy. In line with this thinking, one active listener of radio indicates: 
"Journalists are free enough to publish what they think is right, ee... nobody is being arrested to say because he or she has published a material that is not palatable in the interest of the state, what the government can do is to file a suit of libel against the person and when a radio station is guilty, they found culpable of what they have done" (15- LM).

It can be inferred from the excerpt of the participant that the freedom given to the media in Ghana has made it possible for media personnel to publish whatever information they feel is relevant for the end users. In view of this, audience and for that matter politicians depend on the media to express themselves to gain satisfaction and also win and consolidate power. This dependency relation between the media and the audience is in keeping with the media system dependency theory (Ball-Rokeach and DeFleur 1976) which posits that there is an internal link between the media, the audience, and the social systems. In the context of Ghana, politicians create dependence relationship with their target audience to achieve their political ambitions by using the power of the media to disseminate their policies and programs to influence electorates to either win power or consolidate power. However, the freedom given to the media and journalists have often been misused in most African countries including Ghana. In some cases, the media is used to create an atmosphere of aggression and violence during elections. For instance, Adebayo (2016) revealed that the role the media played as a propaganda weapon during the Rwandan genocide, suggests that the media and its effect on society cannot and should not be underestimated. Relating this scenario to the 2007-8 post-election violence that rocked Kenya, Hoglund (2009) observed that radio broadcasts shortly after the election contributed to fuelling the postelection violence. The study further noted that the major culprits were the vernacular radio stations that broadcast in the local languages of Luo, Kikuyu, and Kalenjin, among others.

Again, the media as a major stakeholder and the fourth arm of government has played a tremendous role in strengthening our democracy and electoral processes in Ghana. It does this through checking the other arms of government (executive, legislature and judiciary), and also uses its powers to allow politicians and citizens to express themselves on media platforms in order to exercise their freedom of speech, and contribute to national development. In view of this, in one of our conversations, a question was posed to the participants to describe the role of the radio during elections and one of the participants explained:

"In an electoral process radio has the capacity to calm the source of information, the source of education, the source of instructions on how the electoral process is due" (13-LU).

In the opinion of the participant, it implies that the media has the capacity to inform and educate people about the dos and don'ts of elections and also instruct the electorate on how to conduct themselves at polling stations. This is also in line with a study in Kenya where it was revealed that in open democracies, citizens not only acquire vital information about various topics from the mass media, but they 
also learn how much importance to attach to the issues in news (Iriri et al. 2017).

In another development, when a question was asked in connection with media freedom and elections, another active listener narrated:

"I feel that we still remain in the military regime, ee... we have given people ee... the freedom to speak their minds, so that they can participate fully and actively in the discourse of national development, but seriously, boss, some people are misusing it" (9- LL).

The submission above suggests that the liberty given to Ghanaians to freely express their opinions without fear or favor are often been misused by creating an atmosphere of aggression and violence. This assertion supports the findings of the reports of the Media Foundation for West Africa language monitory on radio (2013) which highlighted that the use of indecent languages on radio went up from $14 \%$ to $16 \%$ as compared to the preceding two weeks after the 2012 election verdict in Ghana. In this context, the freedom given to radio stations and other media outlets in Ghana, can either promote peace, or create an atmosphere of aggression and violence depending on the decency of language used by the radio stations and the form of information disseminated to the general public. Similarly, a question was asked in relation to how media ownership could have an effect on creating an atmosphere of aggression during elections in Ghana, in response, one of the participants, 7-BR had this to say:

"One of the challenges is that a lot of politicians in Ghana have radio stations that are actually causing problems for the country during elections. When politicians own radio stations, the risks are that, they can use it in their favour during election, Eee...they can use it to misinform, send out wrong information, and use it to create tension in the city, towns and villages. So, there is always a threat of misinformation".

Extracts from the data has not only cast light on how media ownership by few wealthy politicians are used to advance their self-seeking political interests, but are also used as sites for political misrepresentations and misinformation. The expressions also resonate with the propaganda model as articulated by Chomsky and Herman (1988) where they explained that ideally mass media are meant to report events objectively, allow the people to make informed political choices and check on the government power through investigative journalism. However, this is not the case in many instances in Ghana. The revelation highlighted that most Ghanaian influential politicians' own media outlets and news reportage from these media outlets favor the interests of the owners of the media outlets. This way could create an atmosphere of aggression during elections, and may subsequently cause violence elections. In addition, the ability of affluent politicians to own and control some media outlets in Ghana can be interpreted from what Lippmann's describes as the world outside and the pictures in our heads (Lippmann 1922: 49). In the context of Ghana, the world that we will have to deal with is out of reach, out of sight and out of mind because it has to be explored, 
reported and imagined by others, in this case, the few affluent Ghanaian political elites, and the media owners. So, "the pictures inside the heads of the others" that are acted upon by the Ghanaian electorate could be meant to satisfy the interests of the few Ghanaian political elites, the media owners and the affluent in the society. Concerning the same issue, another research participant, 2-RS expressed:

"... ownership is a problem in the radio industry. Politicians have decided to own their own radio stations and by so doing they use the stations to propagate their own ideas and policies. Eee.. their main concern is not about the welfare of the public, but their own self-seeking political interests".

The above information has also shed light on the effects of media ownership by politicians on balance and accurate reportage. In this regard, owners of media houses have the power to influence the production and reproduction of media content to satisfy their egoistic interests. This argument resonates with Sheila (2013) postulation that the media are sometimes used as proxies in the battle between rival political groups, in the process sowing divisiveness rather than consensus, hate speech instead of sober debate, and suspicion rather than social trust.

\section{The Role of Radio in Electoral Education}

As an element of mass media, radio has been extensively used for education, entertainment, social development and information sharing in both developed and developing countries. During our discussion on how the radio is used in setting the agenda for the electorate, and creating an atmosphere of aggression during elections period in the Northern Region of Ghana, the participants were asked to describe the role of radio in educating the electorate during elections and these were the views expressed by a radio presenter:

"The radio educates us about the process of voting, free, fair and transparent elections, violence free elections. Eer... as such that, it also educates us about the policies and ideologies of the various political parties" (14-LW).

In the aforementioned quotes, the participant has illuminated how radio serves as a major source through which the public receives education on the policies, programs and ideologies of the various political parties in Ghana, and as well as an avenue for peace education during elections. In support of this view, Adebayo (2016) explained that the media wields enormous influence regarding how the public view and interpret electoral violence, and provides interpretative frameworks that can lead the public to conclude that either the election was free and fair or was not free and fair. In connection with the same matter, another research participant, a news editor narrated:

"When you look at the last election, we were able to use opinion leaders, we were able to use religious figures, and we were able to use international 
figures, role models to send out messages of tolerance. ... and also, like I said before, radio sends out messages and music and drama which will all persuade us, so radio is so important before elections. Is so important during elections because it is the medium through which you send messages instantly" (1-ZR).

Generally, the participant revealed that radio plays a vital role in elections by using people in authority to advocate for peace before, during elections. In addition, as a mass media communication tool, the radio is the most used medium of communication during elections in Ghana because it reaches out to the general public instantly. The statement also suggests that radio as part of its mandate uses music, and drama in the form of entertainment to persuade the audience with messages of peace and tolerance during elections. Furthermore, the quality of the content produced by media companies are inextricably linked to the quality of human resource and equipment they possess. In relation to this, a question was posed to ascertain some of the challenges faced by media houses in the Northern Region of Ghana, and one of the participants revealed:

"Well, for example, during the last election what we saw was that, the quality of human resources of our radio stations were not the best. Because radio stations do not pay well, their staffs are not the best that we can have. And the quality of interviewing was poor, there was no investigative journalism, nonviolence dissemination of information, eeh... it was clear that they were not doing their work" (4-LY).

The qualities of human resource used in the media houses are very crucial for the creation and re-creation of quality media content for the general public. However, the statement made by the participant indicates that most media houses in the region do not have enough professionally trained personnel to offer quality reportage. Relating this finding to the work of Lynch and McGoldrick (2005) which highlighted that in many parts of Africa, few journalists and media personnel are well trained in the area of peace journalism and conflict analysis. In this regard, the inability of some journalists and media personnel to conduct their work professionally and conflict sensitive reportage could have direct effects on the electoral processes during election because those who are supposed to educate and inform the general public are not well trained, informed, and equipped with professionalism. The data also indicates that some media houses do not pay their staff well and this could lead to unprofessional conducts such as resorting to taking bribes to supplement their meager salaries. In a similar vein, the quality of media personal used, and the quality of training given to media personnel could have an effect on the outcome of the reportage during elections.

Our analysis of the data revealed that the radio is a societal teacher and has the ability to shape the opinion and attitudes of listeners especial during elections. To this end, in response to a question on the influence of the radio during elections, one of the study participants noted that: 
Vol. 6, No. 4 Abdulai: The Role of Radio in Setting the Agenda for the Electorate and...

"In an electoral process, radio has the capacity to calm down the source of information, the source of education, the source of instructions on how the electoral process is due" (3-MT).

From the statement of the participant, it is very clear that radio is used to educate Ghanaian citizens during elections. They do this by giving out guidelines about the processes involved in pre-election activities such as registration of new voters, exhibition exercises. For example, the steps involve in casting votes, voting ethics, conducts at the polling station among other factors. It can further be interpreted to mean that radio has the capacity to give instructions on the dos and don'ts of electoral processes. This understanding is in keeping with the findings of Foster (2010) that the media is used to mold decisions of the electorate and to enlighten people on happenings in the social sphere.

\section{Conclusion}

The paper discusses the role of radio in setting the agenda for the electorate and creating an atmosphere of aggression during elections in the Northern Region of Ghana. Throughout the discussion, the fifteen research participants highlighted that radio plays a vital role in national elections by using people in authority to advocate for peace before, during and after elections. Further, the study revealed that radio as part of its mandate educate its audience with messages of peace and tolerance in order to ensure violence-free national elections. The study illuminates how some media houses and journalists have abused the media as the fourth estate/fourth power by using it to create an atmosphere of aggression during elections. In view of these findings, the study strongly recommends that media practitioners and journalists be trained in media professionalism, focusing on what and how to report during election time in Ghana. Finally, interpretations of the empirical data also cast light on how the media can either promote peaceful elections or create an atmosphere of aggression or violence based on the decency of the language used by radio presenters, reporters, journalists and political activists. Therefore, the study suggests that radio presenters, reporters, and political activists should be educated well on the decency of language used in the media to improve the quality and standards of radio presentation in Ghana.

The findings of this study should be carefully interpreted because the study focuses on the role of radio in setting the agenda for the electorate and creating an atmosphere of aggression during elections in the Northern Region of Ghana. Therefore, generalizing the findings beyond the Northern Region of Ghana may not be scholarly. Again, due to the limited time and resources used for the study, not all the components of media and elections were covered. In connection with this, future studies should consider looking at the role of the media in promoting democratic culture in Ghana. 


\section{References}

Abdulai, M., Ibrahim, H., Mohammed, A. (2017). Communicating Across Cultures in Multinational Ibis West Africa. International Journal of Intercultural Relations, (58): $42-53$

Ball-Rokeach, S. J., DeFleur, M. L. (1976). A dependency Model of Mass-Media Effects". Communication Research 3 (1): 3-21.

Bryman, A. (2004). Social Science Research Methods. New York: Oxford Press

Caput, A. (2011). Preparing Media Coverage of Elections: A Training Guide. Radio for Peace Building in Africa. Retrived: https://www.sfcg.org/programmes/rfpa/pdf/2011 Responsible_Media_Elections_Color_EN.pdf

Chomsky, N., Herman, E. (1988). Manufacturing Consent: The Political Economy of Mass Media. New York: Panthesis.

Creswell, J. W. (2009). Research Design: Qualitative, Quantitative and Mixed Methods Approach (3rd edition). UK: Sage Publications.

FOSDA (2016). Peace Animators. FOSDA Luads SEND-Ghana's Peace Anmators Initiative. Retrieved October 20, 2016, from www.citionlinenews.com.

Foster, S. (2010). Political communication. Edinburgh: Edinburgh University Press.

Gallois, C., Shuang, L., Zala, V. (2011). Introduction to Intercultural: Communication, Global Cultures and Context. London. Sage Publications.

Ghana Statistical Service (2010). Population and Housing Census. Retrieved from http:// www.statsghana.gov.gh/docfiles/2010phc/2010_POPULATION_AND_HOUSI NG _CENSUS_FINAL_RESULTS.pdf

Hoglund, K. (2009). Electoral violence in conflict-ridden societies: concepts, causes, and consequences, Terrorism and Political Violence, 21.

IMPACS (2004). Howard, Ross, 1946: National Library of Canada Cataloguing in Publication. An Election Reporting Handbook

Jarren, O., Donges, P. (2006). Politische Kummunikation in der Mediengesell-schaft, (2nd Edition).

Joey, E. (2012). Ensuring Peaceful Elections in Ghana and Africa. Africa reality. Retrieved October 20, 2016.

Adebayo, J. O. (2016). Fostering nonviolent elections in Africa through conflict-sensitive reportage of elections, African Security Review, 25:3, 303-315.

Ireri K., Ongus, E., Laboso, E., Kangai M., Jared O. (2017). First Level Agenda-Setting: A Study of Press vs. Public Opinion in Kenya. African Journalism Studies, 38:3-4, 2649.

Kuada, J. (2012). Research Methodology. A project Guide for University Students: Aalborg University, Samfunds Litteratur.

Leedy, P. D., Ormrod, J. E. (2005). Practical Research: Planning and Design. $\left(8^{\text {th }}\right.$ ed.). New Jersey: Pearson/Prentice Hall.

Lynch, J., McGoldrick, A. (2005). Peace journalism. Stroud: Hawthorn Press, 2005.

Makinda, S. (1996). Democracy and Multiparty in Africa. The Journal of Modern African Studies, 552-573.

Marshall, P.A. (2003). Human Subjects Protections, Institutional Review Boards, and Cultural Anthropological Research. Anthropology Quarterly, 76(2): 269-85.

Matu, N. (2009). Community Radio and the Post-Election Violence in Kenya. AMARCAfrica.

McCombs, M. (2004). Setting the Agenda: The Mass Media and Public Opinion (Cambridge, MA: Polity Press.

McCombs, M.E., Shaw, D. (1972). The Agenda-Setting Function of Mass Media. POQ, 
Vol. 6, No. $4 \quad$ Abdulai: The Role of Radio in Setting the Agenda for the Electorate and... (36); 176-187

Miller, K. (2005). Communication, Perspectives, Processes and Context. Second Edition. Mc Grew Hill.

Myers, M. (2008). Radio and Development in Africa. A Concept Paper Prepared for the International Development Research Centre (IDRC) of Canada.

Neuman, W.L. (2014). Social Research Methods: Qualitative and Quantitative Approaches $\left(7^{\text {th }} \mathrm{Ed}\right)$. Person Education Limited.

Odhiambo, S.A. (2017). The Media and Election-related Violence in Africa: Lessons from Kenya. Southern Voices Network for Peacebuilding Africa. Program Policy Brief. No. 11

Owusu, W. Y. (2012). The Ghanaian Media Landscape. University of Oxford Press.

Saldaña, J. (2013). The coding manual for qualitative researchers. Sage Publications.

Shaw, L.D and Martin, E. S. 1992.The Function of Mass Media Agenda Setting. Journalism \& Mass Communication Quarterly. 69: 902.

Zhou, S., Kim, Y., Yunjuan L., Fei Q. (2016). Is the agenda set? State of agenda-setting research in China and Korea, Asian Journal of Communication, 26:6, 566-582.

UNDP (2014). Media and Elections. "A guide to Electoral Practitioner" file:///C:/Users/ MUHAMMED/Downloads/2038C-UNDP-Media_and_Elections_LR.pdf.

Vu, H. T., Lei, G., McCombs, M.E. (2014). Exploring "the World Outside and the Pictures in Our Heads": A Network Agenda-Setting Study. Journalism \& Mass Communication Quarterly, Vol. 91(4) 669-686. Sage.

Lippmann, W. (1922). Public Opinion. NY: Macmillan.

Windeck, F. (2010). Political Communication in Sub-Saharan Africa and the role of New Media. The Konrad-Adenauer-Stiffung International Reports. Issue 10.

Yankem (2015). Radio as a tool of political mobilization in Kenya during the 2013 general elections: a case study of Nairobi country. Unpublished master's thesis.

Yin, R. K. (2003). Case Study Research: Design and Methods. (3rd Ed) California: Sage Publication. 


\title{
Linguistic Representations in Selected Presidential Concession Speeches
}

\author{
By Ayo Osisanwo * Emmanuel Chinaguh ${ }^{\dagger}$
}

\begin{abstract}
Defeat comes to politicians with shock and the default response of disappointment; nevertheless, its management has implications for peaceful transition, national stability, and aspirants' democratic and public image. Extant works on election speeches have focused on different aspects of meaning in defeat concession, but have overlooked the ideational aspect of the speeches. Yet, it has the potential of revealing how losing aspirants use language in the realisation of their experiential meanings, within the context of their election defeat. Therefore, this study investigates the linguistic representation of candidates' election defeat experience as embedded in variant themes, together with associated realities that suggest certain political postures. Using Thematics and the Transitivity system of the Systemic Functional Grammar as theoretical framework, representations were purposively taken from presidential concession speeches delivered in Nigeria and the United States, between 2012 and 2016, and subjected to linguistic analysis. The selected data are Romney's Concession Speech (RCS), Jonathan's Concession Speech (JCS), and Clinton's Concession Speech (CCS), which all together comprise 2,145 word corpus and 209 clauses. The analysis identifies the prominent use of four Transitivity processes, which are Material, Relational, Mental and Verbal Processes; and these encrypt candidates' defeat realities across nine themes: Appreciation, Concession, Good Wishes, Recalling Defeat, Closing Ranks, Inclining to Democracy, Framing, A Plea to Fight on, and Benediction. More specifically, the study reveals the actual act of concession to be a Verbalisation in a clause. The paper concludes that the ideational reading of a concession speech transcends yielding to bringing closure to an election, and includes resetting post-election narrative, renewing tarnished image, and keeping the fold together as political postures for future elections.
\end{abstract}

Keywords: concession speech, election defeat, generic structure, transitivity processes.

\section{Introduction}

"Don't let success go to your head and failure to your heart" Will Smith (n.d.)

Elections are held at regular intervals to choose new or retain current leaders that will preside over a political entity for a designated period, usually four years. Elections serve as a process of decision-making among the eligible citizens of a country to select someone for public office through the voting exercise. The pattern and procedure that this process follows is determined by each country's electoral law. The spread of democracy has seen more countries changing from authoritarian rule and embracing democratic government which often emerges through competitive elections. Election affords voters the opportunity to choose who will lead them. It reinforces government's legitimacy, and contributes essentially to democratic governance and sustenance of democracy. Besides

*Lecturer, University of Ibadan, Nigeria.

'Doctoral Student, University of Ibadan, Nigeria. 
serving as an instrument of selecting individuals for public offices, elections are also held to withdraw the mandates given to such persons; this is called "recall election." Plebiscite or referendum is another election type, which is held to decide on a vital national issue. However, the focus of this study only lies with election as a means of choosing leaders.

The reliance on electoral results to decide the cream of the crop demonstrates the primacy of the people's will, which drives democratic government. This originates from the very essence of democracy, viewed as a rule by the peoplemeaning the people are handed the power of governance. The power is ceded in trust to an elected few as trustees of the people's authority. By implication, political power is primarily handed down by the citizenry, and credible, free and fair elections are, therefore, taken for granted for democratic sustenance and the continuity of legitimised governance. This presupposes the presence of competition and contest for power, which in the end is expected to produce the winner and loser. While the winning camp launches into ecstasy for realising their desire for power, the losing camp is left distraught.

\section{Background and Motivation for the Study}

Defeat often comes to politicians with shock after their dashed hopes from a supposedly promising campaign. It comes with the default response of disappointment and painful feeling. For months of gruelling campaign to have ended in failure, may be incomprehensible to the aspirants; and sometimes, the defeat may be highly unexpected, especially when it happens against the projections of forecast polls. Kleinknecht and Shaffir (n.d.) conducted interviews with some defeated politicians and detailed their traumatic experiences as a case study to review the dynamics surrounding career terminations. They surmise that majority of the interviewees relate their loss to the analogy of death to depict the intense disappointment and regret they feel with the defeat.

Inability to accept election loss and distrust of the electoral process have often prompted politicians to reject and protest election results and sometimes mobilise their support base against the authority in a way that threatens the stability, peace and security of a nation. Therefore, how this experience is managed during democratic transition for national unity, stability and the sustenance of democracy is important. At such a crucial time we are able to construe politicians' (unique) inner and outer experience of defeat and the values and beliefs they retain in the face of it (defeat). This is made possible through the resources that language offers. Language indexes experience, intentions, beliefs and other social realities. It is "a human vocal noise or the arbitrary graphic representation of this noise," which is used "systematically and conventionally...for purposes of communication" (Osisanwo, 2008, p. 1). It is the communicative agency that enables speech participants to accomplish different communicative purposes (Bradac, 1999). As a means of public communication, it is used not just to determine whom to entrust with power, and how those in power or desiring power use language to achieve their goals; but it is also used to determine how those who lose contest for power respond and symbolically represent their experiences. 
This is appropriately presented through the Systemic Functional Grammar (SFG), which both accounts for language sociologically as networks (systems) of interlocking options or choices and then the realisation of these options in their structural portion (Halliday, 1985). The first part of the definition is systemic, while the latter is functional. SFG is a linguistic approach that reveals how language serves as a process of making meaning of our inner and external worlds, which consist of goings-on like "happening, doing, sensing, meaning, and being and becoming" (Halliday, 1994, p. 106; Halliday and Matthiessen, 2004, p. 24). This meaning-making process indicates how a speaker's preference for particular linguistic choices communicates some special meanings. So SFL, in this way, implies that language is a set of systems that each offers a different set of meanings based on the context. It emphasises the different realisations of meaning by language use in different contexts. Therefore, within the context of election defeat some understanding would be provided on how losing aspirants use language in the realisation of their experiential meanings. Within the discourse of election defeat, a politician can deliver either a concession or non-concession speech, depending how they choose to respond to their loss. Defeated aspirants deliver concession speeches if they choose to accept the loss and yield power; but if they opt to condemn or even reject the election results, they deliver nonconcession speeches, instead. However, this study is only concerned with the concession speech because of its peaceful closure to a usually heated election campaign, and its significance in promoting and sustaining democratisation, especially in Africa (and Nigeria, in particular).

Previous works on election matters and speeches (Opeibi 2007; Osisanwo 2011, 2012, 2013, 2016a, 2016b, 2016c, 2017; Oyeleye and Osisanwo 2013a, 2013b) have focused on different aspects of election and election defeat, other than the experiential meanings construable through the transitivity processes in election defeat. Related studies by Weaver (1982), Corcoran (1994, 1998), Lakoff (2001), and Mirer and Bode (2015) have discussed the themes, generic structure and rhetorical style of victory and concession speeches. Okoye and Mmadike (2016) and Koussouhon and Dadjo (2016), relying on speech acts and pragmatics, identify the illocutionary acts and the impacts of context in concession speeches. On their part, Anurudu and Oduola (2017) and Adedara (2018) research into some hidden meanings in the genre, using critical discourse analysis. The speech has also been subjected to discourse analysis, like the work of Ademilokun (2016) that investigates use of appraisal resources in concession speeches, and Osisanwo and Chinaguh's (2018) study which explores the discourse relations and intentions in the speeches through rhetorical structure theory.

The most related study to the present one is Ademilokun's because of its discourse analytic orientation, particularly within SFG, and its pre-occupation with the circumstance of politicians' electoral defeat. More precisely, Ademilokun (2016, p. 184) investigates how aspirants use appraisal resources to depict "maturity and positivity in their attitudes and stances to their electoral defeats." However, while his work tilts more towards interpersonal metafunction, which pertains to language choices that give account of speakers' positions towards propositions or social relations between interlocutors; this paper is more ideational in nature and it 
reviews candidates' experiences of election defeat as they are linguistically encoded and represented through the descriptive potential of the transitivity system. This attempt is able to symbolise the changing realities of election defeat as embodied by the variant themes, associated realities that represent face-saving measures for justifying their condescension, value re-orientation among the campaign team, and re-contextualisation of the election defeat for re-building tarnished image, among other experiential functions.

\section{Transitivity System}

The Transitivity system embodies the ideational/experiential meanings of a field of discourse. It reflects the capacity of language as a tool for understanding and how the clause functions and represents the experiential world. As an ideational token of meaning, Transitivity forms part of the three metafunctions of SFG. The other two are interpersonal and textual meanings: while the interpersonal meaning focuses on clause functions as "a form of exchange between speaker and listener" (Halliday, 1985, p. 101), the textual meaning is the interpretation of the clause as message with its two-part structure of theme and rheme; and the making of any stretch of discourse into a coherent and unified text. All the three metafunctions work harmoniously to provide lexico-grammatical patterns in the construal of the world. The Transitivity system shows how the clause, as a grammatical unit, expresses experiential meaning through these (three) semantic categories: the process, realised by a verbal group; the participants, realised by nominal or pronominal elements and they bring about or are affected by the process; and the circumstances that are associated with the process, realised by adverbial or prepositional phrase. The key element here is therefore the process, which is needed to construe the participants' role and the circumstance-this is an optional meaning element. These semantic categories combine to represent the inner and outer experiences of interlocutors. The processes are material, mental, relational, behavioural, verbal and existential processes (Halliday, 1994) as illustrated in Table 1.

Table 1. Transitivity Processes

\begin{tabular}{|c|c|c|c|}
\hline $\mathbf{S} / \mathbf{N}$ & Process Type & Category Meaning & Participants \\
\hline 1. & $\begin{array}{c}\text { Material: } \\
\text { Action } \\
\text { Event }\end{array}$ & $\begin{array}{c}\text { Doing } \\
\text { Doing } \\
\text { Happening }\end{array}$ & Actor, Goal \\
\hline 2. & $\begin{array}{l}\text { Mental: } \\
\text { Perception } \\
\text { Affection } \\
\text { Cognition }\end{array}$ & $\begin{array}{l}\text { Sensing } \\
\text { Seeing } \\
\text { Feeling } \\
\text { Thinking }\end{array}$ & Senser, Phenomenon \\
\hline 3. & Behavioural & Behaving & Behaver \\
\hline 4. & Verbal & Saying & Sayer, Target \\
\hline 5. & $\begin{array}{l}\text { Relational: } \\
\text { Attribution } \\
\text { Identification }\end{array}$ & $\begin{array}{l}\text { Being } \\
\text { Attributing } \\
\text { Identifying }\end{array}$ & $\begin{array}{c}\text { Token, Value } \\
\text { Carrier, Attribute } \\
\text { Identified, Identifier }\end{array}$ \\
\hline 6. & Existential & Existing & Existent \\
\hline
\end{tabular}

Source: Halliday (1985, p. 131) 


\section{Methodology}

The purposively selected data for this paper are Romney's Concession Speech (RCS), Jonathan's Concession Speech (JCS), and Clinton's Concession Speech (CCS), which all together comprise 2,145 words and 209 Elementary Discourse Units (EDUs) or clauses. JCS was selected from Nigeria, while RCS and CCS were selected from the United States. The choice of only one sample from Nigeria as against two from the United States is indicative of the non-prevalence of this genre in the country (Nigeria). The data were segmented into numbered clauses, which formed the units of the analyses, and using the framework of the Transitivity system of SFG the processes, participants and circumstances were identified and classified to construe the defeat experiences of political aspirants as projected through their linguistic constructions.

\section{Data Analysis and Discussion}

The data are analysed and discussed starting with the thematic description of the data, in which case each speech is divided into sections based on its main themes in relation to the speaker's admittance of defeat. Thereafter, the distribution of the transitivity processes in the data is presented containing the frequency of each process across the data and the percentage. The functions of these processes are also discussed in relation to the major themes of the data, so as to symbolically represent the inner and outer experience of election defeat.

\section{Thematic Structures of Defeat Concession}

The thematic structures of the three presidential concession speeches sampled for the study are presented and harmonised as generic structure. In RCS, the following themes were identified and their inherent discourse structure.

\section{Thematic Structure of Romney's Defeat Concession}

The thematic structure of Romney's defeat concession, in Table 2, starts with an Opening Appreciation, from clauses 1-5, that marks the moment the speaker comes on stage and appreciates the audience's applause by repeatedly saying "thank you" or "thank you, my friends"; and the appreciation may also be for the support he got during the election. Thus, it may not really be regarded as a component of the speech; nevertheless, it is included in the transcript. The next theme is Concession and Good Wishes that spans 8 clauses (6-13), and encrypts both the notification by the speaker that he has congratulated the winner and the extending of his best wishes to the winning camp-including the winning candidate, his family, campaign team and supporters. Romney did not directly admit to defeat, he only reported congratulating the winner, which may be regarded as a way of evading defeat. Furthermore, he wished him well, and extended his best regards to the winner's (President Obama's) supporters, campaign team, and family-an act which demonstrates his political maturity. 
The following theme is the candidate's Appreciation of the running mate, family, the campaign team and supporters, which occupies a large part of the speech (from 14-32). The appreciation contains additional information that details why the speaker is thanking each referent. Then there is the theme of Deferring to Democratic Principles in clauses 33-57, whereby Romney calls upon party leaders and the electorate to put aside partisanship to do the people's work; and, thus, admonished them to put the people before politics, anchored on American principles seen to endure beyond an election. He closes with the themes of Benediction and (Closing) Appreciation in clauses 58-63, where he invokes divine blessing on America and appreciates his supporters, again.

Table 2. Thematic Structure of Romney's Defeat Concession

\begin{tabular}{|l|c|c|}
\hline S/N & Themes & Discourse Structure (Clauses) \\
\hline 1. & Opening appreciation & $1-5$ \\
\hline 2. & Concession and good wishes & $6-13$ \\
\hline 3. & $\begin{array}{c}\text { Appreciation to running mates, family, } \\
\text { campaign team and supporters }\end{array}$ & $14-32$ \\
\hline 4. & Deferring to democratic principles & $33-57$ \\
\hline 5. & Benediction and closing appreciation & $58-63$ \\
\hline
\end{tabular}

\section{Thematic Structure of Clinton's Defeat Concession}

The thematic structure of Clinton's defeat discourse similarly starts with an Opening Appreciation in segment 1-5, with each clause serving as a response to the audience's cheers to the candidate as she prepares to deliver the speech. The body of the speech kicks off with its general theme, Concession, and one clause Good Wish for the winner to succeed as American president (within clauses 6-8). In the theme that follows, Recalling Defeat and Closing Ranks, in units 9-42, Clinton reflects on the defeat experience, identifies the shared disappointment everyone in the losing camp feels, and she apologises for the loss. She urges her supporters to accept the election result regardless of their contrary opinion, mainly because of their constitutional democracy.

In the next few clauses, 43-57, the thematic preoccupation of the politician is to get her followers to remain politically involved after the election to advance their democratic values; and in clauses 58-82 she appreciates her campaign team, family and supporters for their contribution to the campaign. The thematic structure in $83-118$, as Table 3 demonstrates, shows the aspirant as rationalising the defeat as a setback that should not deter any of her supporters from fighting for what they believe in. From addressing a general audience, she goes on to specify a group among her followers-the women and little girls-urging them to fight on in spite of the yet to be attained dream for a female American president. The last theme is Closing Appreciation and Benediction in 119-121, which marks the candidate's closing gratitude and invocation of divine blessing on her supporters and the United States of America. 
Table 3. Thematic Structure of Clinton's Defeat Concession

\begin{tabular}{|l|l|c|}
\hline S/N & Themes & Discourse Structure (Clauses) \\
\hline 1. & Opening appreciation & $1-5$ \\
\hline 2. & Concession and good wishes & $6-8$ \\
\hline 3. & Recalling defeat and closing ranks & $43-57$ \\
\hline 4. & Inclining to democracy & $58-82$ \\
\hline 5. & $\begin{array}{l}\text { Appreciation to the campaign team and } \\
\text { supporters }\end{array}$ & $83-118$ \\
\hline 6. & $\begin{array}{l}\text { Framing/rationalising defeat and charging } \\
\text { supporters to keep fighting }\end{array}$ & $119-121$ \\
\hline 7 & Closing appreciation and benediction & \\
\hline
\end{tabular}

\section{Thematic Structure of Jonathan's Defeat Concession}

Table 4 gives a summary of the thematic structure of Jonathan's concession speech. JCS, like other speeches, takes off with an Opening Appreciation; but, contrary to what obtains in RCS and CCS, this theme opens up the real body of the speech. However, it is worth noting that the pre-textual engagement of the speaker with the audience is not captured in the transcript. This is possibly so because the speech was not delivered in the manner of an American concession speech, usually delivered before a standing audience. JCS continues with the thematic preoccupation, Inclination to Democracy, (in units 3-10) where Jonathan affirms that the election was free and fair as he had promised, and he perceives it as a legacy he "will like to see endure" (clause 6). Further demonstrating his inclination to democratic ideals, the speaker admonishes his supporters not to involve with any unconstitutional act in expressing their grievance about the election.

In the next thematic structure in units 11-13, he appreciates the electorate, the security agencies and his party colleagues for their respective roles during the election; and later in 21-22, he thanked Nigerians for the opportunity of leadership. Then with the theme of Framing the defeat discourse in clauses 14-20, the speaker backgrounds the defeat experience and instead foregrounds the achievements of the party in a bid to convince his party colleagues to accept his concession. In unit 23 , he disclosed he had conveyed his best wishes to the winner, General Muhammadu Buhari, and in the concluding clauses (24-24) he gave his Benediction to the Federal Republic of Nigeria, and Closing Appreciation.

Table 4. Summary of Thematic Structure of Jonathan's Defeat Concession

\begin{tabular}{|l|c|c|}
\hline S/N & Themes & Discourse Structure (Clauses) \\
\hline 1. & Opening appreciation & $1-2$ \\
\hline 2. & Inclination to democracy & $3-10$ \\
\hline 3. & $\begin{array}{c}\text { Appreciation of the electorate, party } \\
\text { faithful, and others }\end{array}$ & $11-13 ; 21-22$ \\
\hline 4. & Framing-foregrounding achievements & $14-20$ \\
\hline 5. & Best wishes & 23 \\
\hline 6. & Benediction and closing appreciation & $24-25$ \\
\hline
\end{tabular}




\section{Constructing a Generic Structure for Defeat Concession}

In this part of the paper, the thematic organisations of the speeches are harmonised to derive a generic structure, and this is compared to similar others by Weaver (1982) and Corcoran (1994). Table 5 presents a generic structure for defeat concession, which is constructed by harmonising the thematic structures of RCS, CCS and JCS. The first theme is Appreciation, inclusive of the Opening, Mid-text and Closing Appreciation. It encapsulates all forms of gratitude expressed towards the campaign team, family, supporters and the like. While the Opening Appreciation covers the initial thanks, the Mid-text Appreciation includes all the gratitude extended to different referents in the other parts of the text, with the exception of the Concluding Appreciation that is usually the text-ender along with the Benediction.

Table 5. Generic Structure of Defeat Concession

\begin{tabular}{|c|c|c|}
\hline $\mathbf{S} / \mathbf{N}$ & \multicolumn{2}{|c|}{ Themes } \\
\hline \multirow{3}{*}{1.} & \multirow{3}{*}{ Appreciation } & Opening \\
\hline & & Mid-text \\
\hline & & Closing \\
\hline 2. & \multicolumn{2}{|c|}{ Concession } \\
\hline 3 & \multicolumn{2}{|c|}{ Good Wishes } \\
\hline 4. & \multicolumn{2}{|c|}{ Recalling Defeat } \\
\hline 5. & \multicolumn{2}{|c|}{ Closing Ranks } \\
\hline 6. & \multicolumn{2}{|c|}{ Inclining/Deferring to democracy } \\
\hline 7. & \multicolumn{2}{|c|}{ Framing } \\
\hline 8. & \multicolumn{2}{|c|}{ A Plea to Fight on } \\
\hline 9. & \multicolumn{2}{|c|}{ Benediction } \\
\hline
\end{tabular}

This is followed by Concession and Good Wishes, where the aspirant is expected to concede or admit to defeat, and extend good wishes to the winning camp. However, it has been established by studies that losing candidates often do not directly accept defeat, but rather evade it, an act which Corcoran (1994, p. 115) regards as the "periphrasis of defeat"-"a congratulatory declaration of the winner and an acceptance of the electoral verdict." This plays out in all the speeches, especially in RCS and CCS; but in the case of JCS, there is no linguistic element that marks concession, only implicated by the other thematic acts in the speech, particularly the speaker's best wishes to the winner.

Then we have Recalling Defeat and Closing Ranks. Under these topics, the aspirants may recall their experiences of defeat, including the pain and disappointment they feel as a result of it. In some instances, they also remark on the defeat experience of their supporters as a way of identifying with them. However, this does not seem to be a common theme; thus, it can only be found in CCS in clausal units $18-32$ as below:

I know how disappointed you feel because I feel it too, and so do tens of millions of Americans who invested their hopes and dreams in this effort. This is painful and it will be for a long time... 
Clinton uniquely takes her supporters through the defeat experience, and identifies with them at such a distressed period, deepened by their thwarted high expectations, especially given overwhelming forecast polls that had tipped her to win the election. This theme veers from dwelling unduly on defeat to dealing with it, as aspirants close ranks among their supporters, appealing to them to accept the election result and support the opposing candidate, declared the winner.

In the next theme, the aspirants incline or defer to democracy to remind their supporters of democratic principles-putting the people and country before personal ambitions and politics-and as well justifying their seeming condescension. In RCS, Romney demonstrates how he submits to the democratic will of the nation in units 55-57, as below:

I so wish--I so wish that I had been able to fulfill your hopes to lead the country in a different direction, but the nation chose another leader. And so, Ann and I join with you to earnestly pray for him and for this great nation.

He directly identifies the choice by the majority as that by the nation, and regroups behind the winner to wish his country well. He inherently shows the contest is not all about him, but the belief of the people in his ability to fulfil their "hopes to lead the country in a different direction" (55-57). Similarly, Jonathan rests his ambition for the people in his concession speech when he affirms that "nobody's ambition is worth the blood of any Nigerian."

Thus, this generic structure is a vital part of defeat concession, as it serves as a tool for value re-orientation and it is imperative in driving home the message of concession. It can indeed be regarded as the prop of concession. Framing/ Rationalising Defeat is another major theme in election defeat discourse. It entails the artful deployment of language to re-contextualise defeat experience toward some positive political ends. Mirer and Bode (2015, p. 454) note that concession speech provides the "first opportunity to shape the interpretation of the election as they chart a course forward, or start to rebuild an image tarnished by defeat." In that light, framing is used in this genre as an image management device or a tool for crisis communication, aimed at stemming the negative impact of the election defeat and building a positive political image. In JCS, the candidate framed his concession as a moment to appreciate his achievements in text span 14-20, as below:

Today, the PDP should be celebrating rather than mourning. We have established a legacy of democratic freedom, transparency, economic growth and free and fair elections. For the past 16 years, we have steered the country away from ethnic and regional politics. We created a Pan-Nigerian political party and brought home to our people the realities of economic development and social transformation. Through patriotism and diligence, we have built the biggest and most patriotic party in Nigerian history. We must stand together as a party and look to the future with renewed optimism.

He tries to change his party colleagues' interpretation of the election defeat from "an occasion to mourn" to "a moment to celebrate" the party's achievements. By that, he implores his party, the PDP, to put the defeat behind and work to reclaim power in the future, building on their past achievements. The generic structure 
ends with Benediction, whereby the candidates invoke divine blessing on their country as in RCS and JCS, or both the country and the citizens as in CCS. In JCS, the benediction is "May God Almighty continue to bless the Federal Republic of Nigeria." In CCS, it is "May God bless you and may God bless the United States of America."

The generic structure of the study shares some semblance with earlier ones, like Weaver's (1982) and Corcoran's (1994). Weaver (1982) identifies substantive themes as type of the conventions of concession; and the themes are to declare result formally, call for unity, make a tribute to democracy, give an affirmation of the campaign, acknowledge role transformation, and thank the supporters. The first of Weaver's themes is "Declare result formally" which is embedded in the themes of Concession and Good Wishes in this paper. The second and third are "Call for unity" and "Tribute to Democracy" which both form part of the theme of Inclining/Deferring to Democracy in this paper, but Weaver's second theme-Call for unity-can also function as a subtheme of Closing Ranks depending on the discourse structure. Weaver's other themes, except "Thank supporters" are accounted for differently in this work.

Mirer and Bode (2015) recycle some of Weaver's themes in their paper on the US 2010 congressional, senatorial and gubernatorial elections. They identify themes like declare result formally, give an affirmation of the campaign, acknowledge role transformation, and thank the supporters. Corcoran (1994, 1998), on his part, classifies four elements of a concession speech to be the periphrasis of defeat, a call to unite behind the winner, the paean to democracy, and a plea to continue the fight. These themes are equally similar to the generic structure constructed in this study. However, some themes are noticeably omitted in Corcoran's work, like Appreciation, Closing Ranks and Benediction; but he acknowledges there are common subthemes, like an appeal to the young ones and remarks about the gruelling campaign. These subthemes are related to the theme of Closing Ranks. Furthermore, framing is only perceived by Corcoran as a strategy, rather than as a theme.

\section{Generic Structure and Transitivity Processes in Defeat Concession}

Table 6 illustrates the number of clauses in the generic structures of defeat concession, and the distribution of transitivity processes in each structure and the entire data. This is also represented in Figure 1. Appreciation takes the largest share of the discourse units, 68 out of a total of 209 , which is $32.5 \%$, as pictorially represented with the pie chart in Figure 1. This is followed by Inclining to Democracy, with a frequency of 48 and taking the second largest share of the genre at $23 \%$. The themes with the least clauses are Concession and Best Wishes each with a distribution of $2.9 \%$, and Benediction, at the lowest rung both in order and frequency, with $1.9 \%$. Thus, these findings illustrate that defeated aspirants devote very intangible space to concession, and rather refocus the speech as a medium of thanking their supporters, family, party colleagues and the electorate; and deferring to democratic principles to remind supporters and party faithful that the people come first before political ambitions. 
Table 6. Frequency of Clauses in the Generic Structure of Defeat Concession

\begin{tabular}{|c|c|c|c|c|c|c|c|c|c|c|c|c|}
\hline \multirow{2}{*}{$\mathbf{S} / \mathbf{N}$} & \multirow{2}{*}{ Themes } & \multirow{2}{*}{ Mat. } & \multicolumn{4}{|c|}{ Mental } & \multicolumn{2}{|c|}{ Relational } & \multirow{2}{*}{ Verb. } & \multirow{2}{*}{ Exist. } & \multirow{2}{*}{ Beh. } & \multirow{2}{*}{ Total } \\
\hline & & & Cog. & Emot. & Des. & Perc. & Attrib. & Ident. & & & & \\
\hline \multirow{2}{*}{1.} & \multirow{2}{*}{ Appreciation } & \multirow{2}{*}{$15: 22.1 \%$} & $3: 4.4 \%$ & $2: 2.9 \%$ & $7: 10.3 \%$ & 0 & $10: 14.7 \%$ & $5: 7.4 \%$ & \multirow{2}{*}{$26: 8.2 \%$} & \multirow{2}{*}{0} & \multirow{2}{*}{0} & \multirow{2}{*}{$68: 32.5 \%$} \\
\hline & & & & $12: 17$ & & & $15: 2$ & & & & & \\
\hline \multirow{2}{*}{2.} & \multirow{2}{*}{ Concession } & \multirow{2}{*}{$2: 33.3 \%$} & 0 & 0 & 0 & 0 & $2: 33.3 \%$ & 0 & \multirow{2}{*}{$2: 33.3 \%$} & \multirow{2}{*}{0} & \multirow{2}{*}{0} & \multirow{2}{*}{$6: 2.9 \%$} \\
\hline & & & & 0 & & & & & & & & \\
\hline \multirow{2}{*}{3.} & \multirow{2}{*}{ Good wishes } & \multirow{2}{*}{$1: 16.7 \%$} & 0 & 0 & $3: 50 \%$ & 0 & 0 & $1: 16.7 \%$ & \multirow{2}{*}{$1: 16.7 \%$} & \multirow{2}{*}{0} & \multirow{2}{*}{0} & \multirow{2}{*}{$6: 2.9 \%$} \\
\hline & & & & $3: 50$ & & & $1: 1$ & & & & & \\
\hline \multirow{2}{*}{4.} & \multirow{2}{*}{ Recalling defeat } & $4.266 \%$ & $1: 6.7 \%$ & $2: 13.3 \%$ & 0 & 0 & $6: 40 \%$ & $1: 6.7 \%$ & 0 & 0 & $1.67 \%$ & $15 \cdot 72 \%$ \\
\hline & & 4.20 .010 & & $3: 20$ & & & $7: 4$ & & 0 & 0 & 1.0 .110 & 10.1 .210 \\
\hline & & & $4: 21 \%$ & $3: 15.8 \%$ & 0 & $1: 5.3 \%$ & $4: 21 \%$ & $1: 5.3 \%$ & 0 & 0 & & $19 \cdot 91 \%$ \\
\hline כ. & Closing ranks & $5: 20.5 \%$ & & $8: 42$ & & & $5: 2$ & & U & 0 & $1.5 .5 \%$ & $19: 9.1 \%$ \\
\hline 6. & Inclining to & $20: 41.7 \%$ & $7: 14.6 \%$ & $1: 2.1 \%$ & $1: 2.1 \%$ & 0 & $5: 10.4 \%$ & $3: 6.2 \%$ & $7 \cdot 146 \%$ & $1.21 \%$ & $3.62 \%$ & $48.23 \%$ \\
\hline & democracy & 20.71 .96 & & $9: 18$ & & & $8: 1$ & & (1.10 & 1.2 .176 & 5.0 .210 & (10.20 \\
\hline 7. & Framing & $7: 58.3 \%$ & 0 & 0 & 0 & 0 & $4: 33.3 \%$ & $1: 8.3 \%$ & 0 & 0 & 0 & $12.57 \%$ \\
\hline & & & & 0 & & & $5: 4$ & & 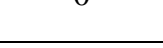 & 0 & 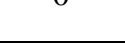 & (12.5. \\
\hline 8. & A plea to fight on & $9: 29 \%$ & $6: 19.4 \%$ & $2: 6.5 \%$ & $1: 3.2 \%$ & 0 & $9: 29 \%$ & 0 & $1.3 .2 \%$ & $2: 6.5 \%$ & $1: 3.2 \%$ & $31: 14.8 \%$ \\
\hline & & & & $9: 29$ & & & & & & & & \\
\hline 9 & Benediction & $4 \cdot 100 \%$ & 0 & 0 & 0 & 0 & 0 & 0 & 0 & 0 & 0 & $4 \cdot 19 \%$ \\
\hline . & Dentive & T.100 & & 0 & & & & & 0 & 0 & 0 & 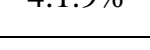 \\
\hline Total & & 67:32.1\% & 21:10.1\% & $10: 4.8 \%$ & $12: 5.7 \%$ & $1: 0.5 \%$ & 40:19.1\% & $12: 5.7 \%$ & $7: 177 \%$ & $3.1 .4 \%$ & $6.2 .9 \%$ & 209 \\
\hline & & & & 44:21 & & & $52: 2$ & & - & (0.0. & 0.20 & 20 \\
\hline
\end{tabular}


Figure 1. A Pie Chart Representing the Generic Structure of Concession Speeches

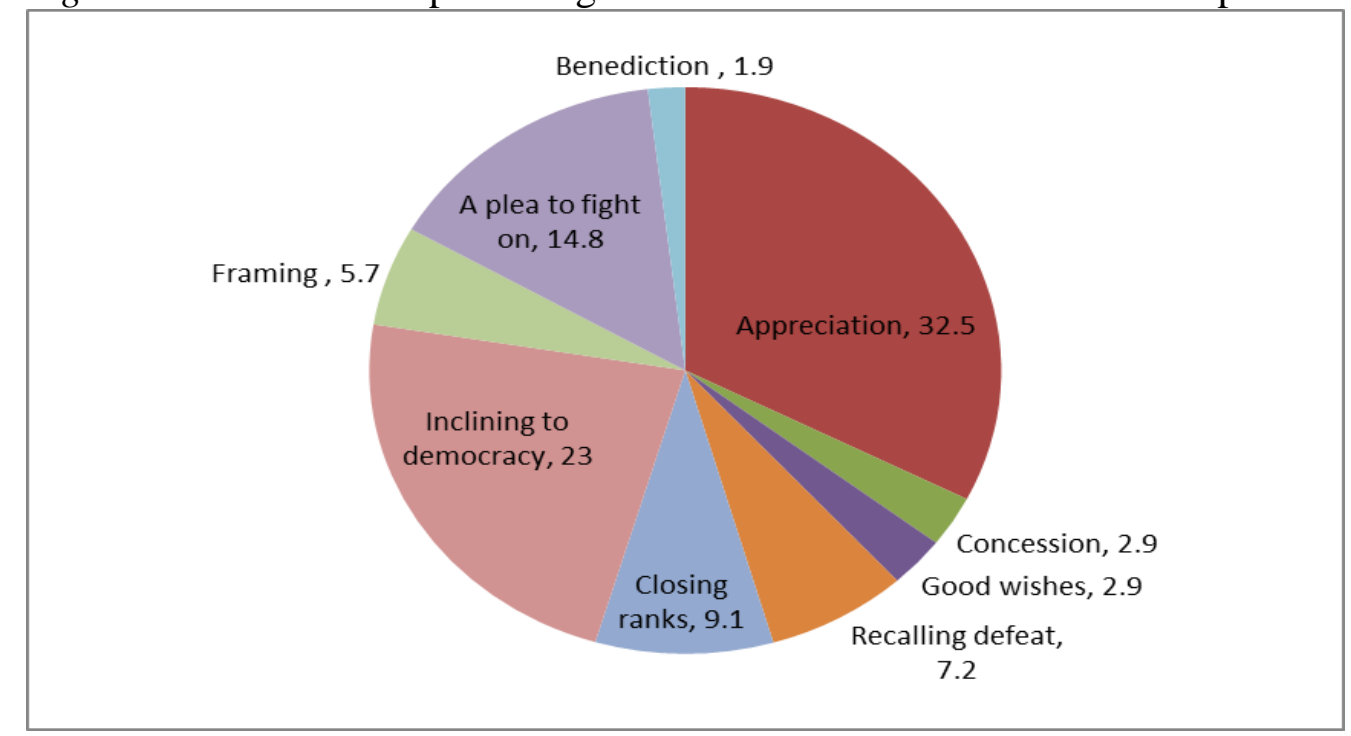

Within each thematic constituent, some transitivity processes feature prominently to symbolically represent the candidates' inner and outer experience of defeat, as in Figure 2. For instance, the aspirants appreciated their supporters mostly through verbal, material and relational attributive processes, with $38.2 \%$, $22.1 \%$ and $14.7 \%$ distribution, respectively (see Figure 3). Also, politicians incline to democratic tenets significantly through actions/events (material processes) which featured in $41.7 \%$ of the discourse units. For the Concession theme, the clauses are equally shared by material, relational attributive and verbal processes (at 33.3\% each); while it is all material under Benediction (100\%)-although, the units are very small (just 4 clauses).

Figure 2. A Histogram Showing the Distribution of Transitivity Processes within Concession Themes

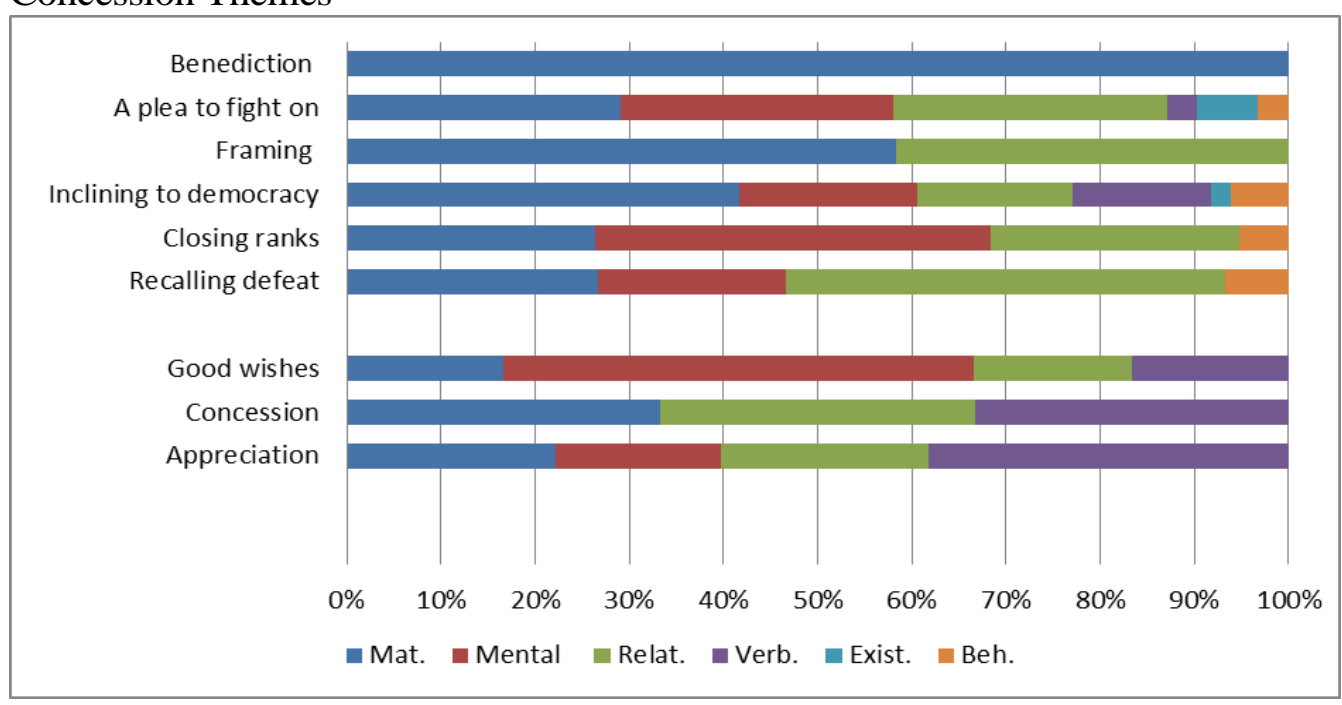




\section{Figure 3. A Pie Chart of Transitivity Processes in Concession Speeches}

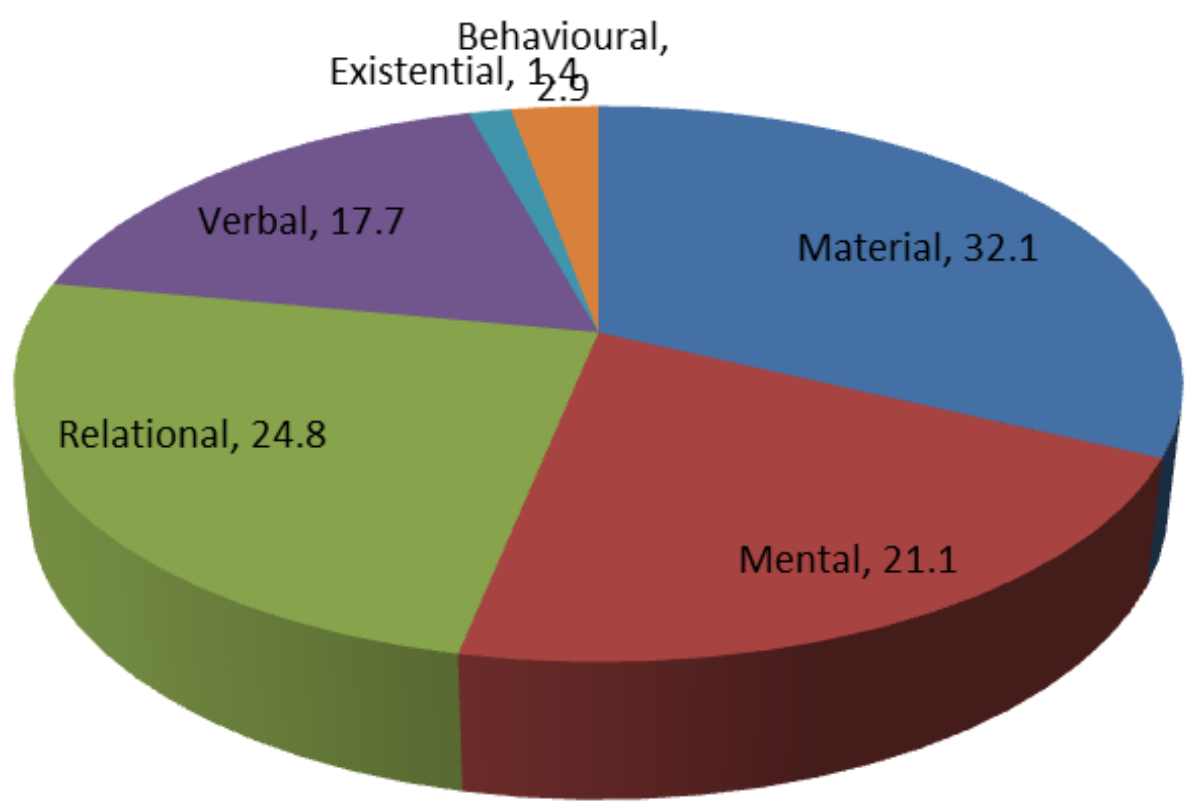

In the entire data, four processes are mostly distributed, as presented in Figure 3 . These processes are material (32.1\%), relational (24.8\%), largely attributive, mental $(20.1 \%)$, half cognitive, and verbal (17.7\%). The other two are behavioural and existential processes with very low distribution of $2.9 \%$ and $1.4 \%$ respectively. The finding aligns with earlier works that acknowledge material, mental and relational processes as major transitivity processes, but this study adds verbal processes to the list, especially in regard to political concession speeches. In the subsequent part of the analysis, the functions of the transitivity processes are examined and discussed within the generic structures, motivated by their distinctive usage in the genre of (admitted) election defeat discourse.

\section{Experiential Functions of Transitivity Processes in Election Defeat Discourse}

\section{Transitivity Processes in Appreciating Supporters during Concession}

As losing aspirants, by their concession, give a closure to their intense electoral contest, they devote most content to appreciating their supporters and others involved in their campaign. Hence their actual concession is glossed over to (at least) satisfy the media's demand (especially with the American speeches); the speech is rather exploited as a moment to acknowledge the dedication of their followers, regardless of the defeat. Their gratitude is mostly verbalised (verbal processes: 38.2\%), echoing the actions/events (material processes: 21.1\%) motivating the gesture, and how it is differently characterised and identified (relational processes: $21.1 \%$ ), and mentally projected (17.6\%). These are illustrated in the following segments. 


\section{Verbalisation of Appreciation in Defeat Concession}

The aspirants express their gratefulness towards their campaign team through the verb thank used both in the US and Nigerian speeches, and other verbs like congratulate, commend and assure, each used singly, in the Nigerian speech only. Thus, JCS (the Nigerian Speech) extends the appreciation theme to accommodate expression of good wishes to the citizens, and guarantee them of his willingness to keep doing his best (in spite of his loss), and as well laud the security services. The instances of this usage are presented in Table 7. These instances affirm the ubiquity of the verb thank in the aspirants' attempt at verbalising their appreciation to the citizens, families and supporters. In the first example, Romney verbalises his gratitude through the verb thank to signal his appreciation towards his supporters, represented with the pronoun you, the Target of the verbalisation, who were verbally acted upon. The Circumstance "so very much" signifies the Extent of the symbolised meaning. In unit 20 of RCS, Romney indicates the Sayer, I, of the verbal process that encodes the signal source through the same verb thank, but narrows down the Target to "my sons" in consideration (Circumstance: Reason) that they have worked tirelessly on behalf of the campaign. Similar trend can be found in examples 3-5, all signalling similar meaning through the verb thank, and denoting the Circumstance of Reason, Extent or both.

The exception is Example 6 in JCS, where the Sayer $I$ clearly encodes a congratulatory remark towards the Target, Nigerians, "for successfully going through the process of the March 28th General Elections..." Jonathan takes his Appreciation beyond being thankful to applauding the political participation of the citizens, an act which portrays the candidate as stately. It can, therefore, be deduced that verbal transitivity processes within the theme of Appreciation, present politicians who concede as handling their defeat well in the interest of the nation.

Table 7. Verbalisation of Appreciation in Defeat Concession

\begin{tabular}{|c|c|c|c|c|c|}
\hline $\mathbf{S} / \mathbf{N}$ & Sayer & $\begin{array}{l}\text { Verbal } \\
\text { Process }\end{array}$ & Target & Verbiage & Circumstance \\
\hline 1. & & Thank & You & - & so very much ${ }_{2}$ RCS (Extent) \\
\hline 2. & I & Thank & my sons & - & $\begin{array}{l}\text { for their tireless work on behalf of } \\
\text { the campaign } \\
20 \text { RCS (Reason) }\end{array}$ \\
\hline 3. & - & Thank & You & - & $\begin{array}{l}\text { so very much for being here }{ }_{4} \mathrm{CCS} \\
\text { (Extent, Reason) }\end{array}$ \\
\hline 4. & $\begin{array}{l}\text { We- } \\
\text { we }\end{array}$ & Thank & You & - & $\begin{array}{l}\text { for your graceful, determined } \\
\text { leadership }{ }_{63} \text { CCS (Reason) }\end{array}$ \\
\hline 5. & I & Thank & you all & - & $\begin{array}{l}\text { for turning out en-masse for the } \\
\text { March } 28 \text { General Elections } 2 \text { JCS } \\
\text { (Reason) }\end{array}$ \\
\hline 6 & I & Congratulate & Nigerians & & $\begin{array}{l}\text { for successfully going through the } \\
\text { process of the March } 28 \text { th General } \\
\text { Elections with the commendable } \\
\text { enthusiasm and commitment that } \\
\text { was demonstrated nationwide }{ }_{11} \\
\text { JCS (Reason) }\end{array}$ \\
\hline
\end{tabular}




\section{Representing Actions and Events of Appreciation in Concession}

While the Appreciation of conceding aspirants is mostly verbalised, it is largely demonstrated with actions and events that chronicle the activities of their supporters and party colleagues, deserving gratitude. This refers to the supporters' concrete and abstract actions and events associated with them, which contributed to the campaign; although, the campaign ends in defeat, the politicians reckon their supporters' efforts should be acknowledged and applauded.

As illustrated in Table 8, the aspirants deploy material processes to detail the contributions of their families, running mates, and supporters towards the election, despite their loss. So, Example 7 provides additional information to explain why Romney had thanked his daughters-in-law and their children in the preceding clause. Similarly, the material clause in Example 9 (unit 66) buttresses Clinton's prior expression of her loving gratitude to her family in unit 65. Same applies with the other examples, which are mostly instanced by Range to delineate the scope of the illustrative material processes. In addition, not all the processes are concrete actions; there are abstract actions like in Example 11 where the Actor $I$ is described as having "poured out" their hearts into the campaign. Thus, conceding politicians by their use of material processes in their Appreciation of supporters, fully identify with their camp and do not abandon them, as responsible leaders undaunted by defeat.

Table 8. Representation of Actions and Events of Appreciation in Concession

\begin{tabular}{|c|c|c|c|c|c|c|}
\hline $\mathbf{S} / \mathbf{N}$ & Actor & $\begin{array}{l}\text { Material } \\
\text { Process }\end{array}$ & Goal & Range & Beneficiary & Circumstance \\
\hline 7. & $\begin{array}{c}\text {...as } \\
\text { their } \\
\text { husbands } \\
\text { and dads }\end{array}$ & have spent & - & $\begin{array}{l}\text { so many } \\
\text { weeks }\end{array}$ & - & $\begin{array}{l}\text { away from home } 22 \text { RCS } \\
\text { (Place) }\end{array}$ \\
\hline 8. & They & have made & & $\begin{array}{l}\text { an } \\
\text { extraordinary } \\
\text { effort }\end{array}$ & $\begin{array}{l}\text { not just for } \\
\text { me but for } \\
\text { the country } \\
\text { that we } \\
\text { love }_{24} \text { RCS }\end{array}$ & \\
\hline 9. & You & crisscrossed & & this country & & $\begin{array}{c}\text { On our behalf }{ }_{66} \text { CCS } \\
\text { (Behalf) }\end{array}$ \\
\hline 10. & $\cdots$ & and gives & $\mathrm{Me}$ & $\begin{array}{l}\text { great hope } \\
\text { and comfort }\end{array}$ & & $\begin{array}{l}\text { to know that Tim will } \\
\text { remain on the front lines } \\
\text { of our democracy }{ }_{61} \text { CCS } \\
\text { (Matter) }\end{array}$ \\
\hline 11. & You & poured out & $\begin{array}{c}\text { your } \\
\text { hearts }\end{array}$ & & & $\begin{array}{c}\text { into this campaign } \\
\text { CCS (Place) }\end{array}$ \\
\hline
\end{tabular}

\section{Attributive and Identifying Elements in the Appreciative Remarks of Conceding Politicians}

There are processes that characterise and identify politicians' theme of Appreciation in the genre of concession. They are the relational processes that index thankful attributes like acknowledgement of joyous feeling and expression 
of gratitude towards followers, and identifying properties like the kind of First Lady an aspirant's wife would have been and whether the campaign was the first or one among many to some supporters. This is further illustrated in Table 9. Example 12 is an identifying relational process in RCS, where the identified "She"-who is Romney's wife-is presumed "would have been" (the identifying process) "a wonderful first lady" (the Identifier), if Romney had won the election. The speaker made the expression just after thanking his wife in unit 16. The last two examples are attributive relational processes in CCS, which are the speaker's attribution of her gratitude towards her team in Example 13, and the joy she feels getting to know his campaign partners better in Example 14. These processes represent how the aspirants further engage with their campaign team and supporters as they appreciate them for their efforts.

Table 9. Attributive and Identifying Elements in the Appreciative Remarks

\begin{tabular}{|l|c|c|c|c|}
\hline S/N & Participant & Relational Process & Participant & Circumstance \\
\hline 12. & $\begin{array}{c}\text { She } \\
\text { (Identified) }\end{array}$ & $\begin{array}{c}\text { a wonderful } \\
\text { would have been } \\
\text { (Identifying) } \\
\text { RCS lady }\end{array}$ & $\begin{array}{c}\text { RC } \\
\text { (Identifier) }\end{array}$ & - \\
\hline 13. & $\begin{array}{c}\text { I } \\
\text { (Carrier) }\end{array}$ & $\begin{array}{c}\text { am } \\
\text { (Attributive) }\end{array}$ & $\begin{array}{c}\text { so grateful } \\
\text { (Attribute) }\end{array}$ & $\begin{array}{c}\text { To stand with all of } \\
\text { you }{ }_{58} \text { CCS }\end{array}$ \\
\hline 14. & $\begin{array}{c}\text { It } \\
\text { (Carrier) }\end{array}$ & $\begin{array}{c}\text { has been } \\
\text { (Attributive) }\end{array}$ & $\begin{array}{c}\text { a joy } \\
\text { (Attribute) }\end{array}$ & $\begin{array}{c}\text { getting to know } \\
\text { them better }\end{array} 6$ CCS \\
\hline
\end{tabular}

\section{Transitivity Indices of Concession as a Discourse Unit}

As earlier mentioned, aspirants devote minimal discourse units to concession, although the global coherence of the speech remains Concession as affirmed by Osisanwo and Chinaguh (2018). It is thus plausible to construe how the discursive construction of the aspirants' concession reflects their experience of defeat; and premium is particularly given to how transitivity processes are eked out in these core discourse units, to encode equal distribution of action, verbal and relational (attributive) processes-each featuring in two clauses. The nucleus of the processes, which symbolically signal the concession, is the verbal processes, realised either through independent clause/event as in Example 15, or infinitive clause/dependent event as in Example 16.

Table 10 presents verbal process in concession. Thought functionally as an independent meaning token, the verbal process in Example 15a is not subordinated to the material process; rather the material process is another independent process that encrypts the aspirant's offer to support the opponent's administration-so, she moved past the defeat in the interest of the country. In addition, the encoding of the verbal process in Example 15a can be construed as an autonomous entity, and it gives subtle ideation about the attitude of the speaker to defeat-which may be interpreted as directly dwelling on the defeat discourse, and not evading it as has been previously observed in concession genre. 
Table 10. Verbal Process in Concession

\begin{tabular}{|c|c|c|c|}
\hline $\mathbf{S} / \mathbf{N}$ & Material/Verbal Processes & & Material/Verbal Processes \\
\hline $15 \mathrm{a}$ & $\begin{array}{c}\text { [Circumstance] [Sayer] } \\
\text { [Verbal] [Target] } \\
\text { Last night, I congratulated } \\
\text { Donald Trump } 6\end{array}$ & $15 b$. & $\begin{array}{l}\text { [material] } \\
\text { and offered to work with him on } \\
\text { behalf of our country }{ }_{7} \text { CCS }\end{array}$ \\
\hline $16 \mathrm{a}$ & $\begin{array}{c}{[\text { Actor }] \quad[\text { Material }]} \\
{[\text { Goal }]} \\
\text { I have just called President Obama } 6\end{array}$ & $16 b$. & $\begin{array}{c}\text { [Verbal] [Target] } \\
\text { [Circumstance] } \\
\text { to congratulate him on his victory } \\
\text { RCS }\end{array}$ \\
\hline
\end{tabular}

Table 11. Relational Process in Concession

\begin{tabular}{|c|c|c|c|}
\hline S/N & Carrier & Relational Process (Attributive) & Attribute \\
\hline 17. & $\begin{array}{c}\text { His supporters and } \\
\text { his campaign }\end{array}$ & also deserve & congratulations \\
\hline 18. & $\begin{array}{c}\text { His supporters and } \\
\text { his campaign }\end{array}$ & also deserve & congratulations \\
\hline
\end{tabular}

On the contrary, the verbal process in Example 16b is an infinitive clause whose meaning is dependent on the material process in Example 16a. The speaker first reports calling his opponent, President Obama, who is the Goal. Although, that action itself is an implied concession based on the contextual knowledge that "making the call" to an opponent after the declaration of election results is accepting defeat. Nevertheless, the purpose for the call is specified through the verbalisation of the concession, with the verb congratulate-as the enactment of a public speech act of concession. In other words, even though the verbalisation of concession is subordinated here, as a discourse strategy for prevaricating defeat, it is still the key act of the concession speech, especially in the US; otherwise, merely saying "I have called President Obama" should suffice as an implied concession. The relational processes that follow in Examples 17 and 18, as represented in Table 11, are one repeated clause to state that the opponent's supporters also deserve congratulations. Such maturity marks how Romney transforms his election defeat to a different reality that stimulates dignity and grace.

\section{Transitivity Functions in Recalling Defeat and Closing Ranks in Concession Genre}

The themes of Recalling Defeat and Closing Ranks only appear in CCS to reminisce about the campaign and the outcome, acknowledge the pain of defeat and apologise for it, and reorient the supporters to regroup behind the winner. These meanings were mainly symbolised by relational (especially attributive), mental (mostly cognitive and emotive) and material processes, as represented in Table 12. Through the relational processes, Clinton identifies the outcome of the election as being unfavourable in Example 19a, and apologises to her supporters for it in 19b, an uncommon act among conceding aspirants, who seldom admit defeat. The material clause in Example 19c merely states the event that prompted 
the speaker to offer an apology to the followers; and in other segments of the theme it also acts as an illustrative process, similar to its ideational function within other themes. The mental processes construe the inner worlds of the losing camp, which mostly are their emotive and cognitive dispositions to the election defeat, like the feeling of disappointment, as represented in 19d and 19e.

Table 12. Transitivity Process in Concession

\begin{tabular}{|c|c|c|c|}
\hline $\mathbf{S} / \mathbf{N}$ & Themes & Transitivity Processes & Examples \\
\hline 19. & $\begin{array}{c}\text { Recalling } \\
\text { defeat }\end{array}$ & $\begin{array}{ll}\text { a. } & \text { Relational(Identifying) } \\
\text { b. } & \text { (Attributive) } \\
\text { c. Material } \\
\text { d. Mental (Cognitive) } \\
\text { e. (Emotive) }\end{array}$ & $\begin{array}{l}\text { a. This is not the outcome we wanted or } \\
\text { worked so hard for } \\
\text { b. and I'm sorry } \\
\text { c. that we did not win this election } \\
\text { d. I know how disappointed you feel } \\
\text { d. } \\
\text { e. because I feel it too }{ }_{19} \text { CCS }\end{array}$ \\
\hline 20. & $\begin{array}{l}\text { Closing } \\
\text { ranks }\end{array}$ & $\begin{array}{ll}\text { a. } & \text { Relational } \\
& \text { (Identifying) } \\
\text { b. } & \text { (Attributive) } \\
\text { c. } & \text { Material } \\
\text { d. } & \text { Mental Cognitive }\end{array}$ & $\begin{array}{l}\text { a. Donald Trump is going to be our } \\
\text { president } 34 \\
\text { b. We owe him an open mind and the } \\
\text { chance to lead } \\
\text { c. Our constitutional democracy enshrines } \\
\text { the peaceful transfer of power }{ }_{36} \\
\text { d. But I still believe in America }{ }_{29} \mathrm{CCS}\end{array}$ \\
\hline
\end{tabular}

The mental processes further reveal the concern and consciousness of the aspirant and her supporters about issues arising from the campaign, and their cognitive and emotive responses to these issues. One of the issues is the perceived deep division in America, which did not dissuade the aspirant from expressing belief in the nation in $20 \mathrm{~d}$, and mobilising the supporters to do the same. That mental disposition was informed by their yielding identification (through the relational process) in Example 20a that Donald Trump will be the president; and through another relational process, the aspirant reminds the supporters of their required allegiance to him (as the newly elected president) in $20 \mathrm{~b}-$ this is premised on the following material process in 20c that illustrates the constitutional demand for peaceful transfer of power. So, the transitivity processes in this theme avail us of the inner experiences, including concerns, of defeat and the outer efforts taken to yield to it and getting supporters to realign, accordingly.

\section{Transitivity Processes Activating Democratic Inclination in Political Concession}

As politicians yield power after an election, they are preoccupied with seamless democratic transition and their articulation mostly comprises actions and events that lean towards democratic ideals. On one hand, this involves brief narratives of efforts and actions during the election; on the other hand, it entails implored actions to continue advancing core values and principles regardless of the defeat. This is besides the recurring illustrative and other accompanying actions and events to other transitivity processes that project the cognitive drive (mental processes) of these actions, characterise and identify (through relational 
processes) the democratic ideals spurring these actions, and affirm them (through verbal processes) to symbolise the aspirants' inclination to democracy.

Table 13 presents ideational functions and transitivity processes in concession. Examples 21a-c are material processes that detail politicians' actions and efforts towards realising their ambitions, perhaps to convince supporters that they had done their best, in spite of their loss. While in 21a, the Actor We inclusively recount that the team had given their all to the campaign; in $21 \mathrm{~b}-\mathrm{c}$, the Actor We also specify the length of time they had collectively spent in reaching out to people across the country. This ideational function correlates with another metafunction, where candidates implore supporters to take certain actions in the interest of the nation, looking past the electoral defeat. Through the material process in 22a, Romney wants his party colleagues to shirk partisanship to get past the challenges of the transition period; and through another material process in $22 \mathrm{~b}$, Clinton through a collective personal pronoun $u s$ in "let's" implores her supporters to join her in continuing to advance their "causes and values" by always participating in the affairs of the country.

Table 13. Ideational Functions and Transitivity Processes in Concession 1

\begin{tabular}{|c|c|c|c|}
\hline $\mathbf{S} / \mathbf{N}$ & $\begin{array}{l}\text { Ideational } \\
\text { Functions } \\
\end{array}$ & Examples & $\begin{array}{c}\text { Transitivity } \\
\text { processes }\end{array}$ \\
\hline 21. & $\begin{array}{l}\text { Projecting } \\
\text { efforts } \\
\text { during } \\
\text { election }\end{array}$ & $\begin{array}{l}\text { a. We have given our all to this campaign } \\
\text { RCS } \\
\text { b. We've spent a year and a half }{ }_{49} \mathrm{CCS} \\
\text { c. Bringing together millions of people from } \\
\text { every corner of our country }{ }_{50} \mathrm{CCS}\end{array}$ & $\begin{array}{l}\text { Material } \\
\text { Material } \\
\text { Material }\end{array}$ \\
\hline 22. & $\begin{array}{l}\text { Implored } \\
\text { democratic } \\
\text { actions } \\
\text { after } \\
\text { election }\end{array}$ & $\begin{array}{l}\text { a. At a time like this, we can't risk partisan } \\
\text { bickering and political posturing }{ }_{34} \text { RCS } \\
\text { b. So, let's do all we can to keep advancing } \\
\text { the causes and values we hold dear }{ }_{45} \text { CCS }\end{array}$ & $\begin{array}{l}\text { Material } \\
\text { Material }\end{array}$ \\
\hline 23. & & $\begin{array}{l}\text { a. I promised the country free and fair } \\
\text { elections } \mathrm{JCS}_{3} \\
\text { b. I have kept my word } \mathrm{JCS}_{4}\end{array}$ & $\begin{array}{c}\text { Verbal } \\
\text { Material }\end{array}$ \\
\hline 24. & actions & $\begin{array}{l}\text { a. So now, our responsibility as citizens is to } \\
\text { keep doing our part }{ }_{55} \mathrm{CCS} \\
\text { b. to build that better, stronger, fairer America } \\
\text { we seek }{ }_{56} \mathrm{CCS}\end{array}$ & $\begin{array}{l}\text { Relational } \\
\text { Material }\end{array}$ \\
\hline
\end{tabular}

The predominance of action processes in advocating democratic tenets is further reflected in the illustrative/accompanying function of these processes with others. As in Example 23, Jonathan did not only give a verbal signal (to promise) "free and fair" election, he also evidenced it by an action (that he has kept the promise). Similarly, in 24, while Clinton identifies the civil responsibility of her supporters to continue doing their part, she deploys a material action to illustrate what that entails to be "build(ing) that better, stronger, fairer America we seek." Altogether, losing aspirants do not only incline to democratic ideals but mobilise towards democratic actions in deference to the constitution. 


\section{Deployment of Action and Attribution Processes in Framing Defeat}

The candidates engage material and relational processes in framing their defeat discourse, depending whether their goal is to deflect attention to some positive political events, like their achievements, or rationalise their defeat. In redirecting focus to achievements, action processes are deployed to etch these positive political moments so as to push back the thought of defeat. This is prevalent in JCS, a difficult speech delivered by an incumbent president who lost re-election in a country where concession was hitherto unknown; and the speaker decides to use the moment to celebrate past accomplishments rather than focusing on present defeat. This is represented in Examples 25a-c (see Table 14).

In the second instance, defeat is rationalised as one of life's setbacks through the successive use of relational (attributive) processes as demonstrated in CCS. In Examples 26a-c, Clinton gets by her election defeat by diminishing its importance. More specifically in 26a and 26b, the speaker as the Carrier I characterise respectively that she has had successes and so are setbacks (as the Attributes). She perceives it as normal life's experience as she in $23 \mathrm{c}$ informs the supporters that they "will have successes and setbacks too" just like she has had. The strategic goal is to circumvent defeat.

Table 14. Ideational Functions and Transitivity Processes in Concession 2

\begin{tabular}{|c|c|c|c|}
\hline $\mathbf{S} / \mathbf{N}$ & $\begin{array}{l}\text { Ideational } \\
\text { Functions }\end{array}$ & Examples & $\begin{array}{l}\text { Transitivity } \\
\text { processes }\end{array}$ \\
\hline 25. & $\begin{array}{l}\text { Celebrating } \\
\text { achievements }\end{array}$ & $\begin{array}{l}\text { a. Today, the PDP should be celebrating } \\
\text { rather than mourning } 14 \text { JCS } \\
\text { b. We have established a legacy of democratic } \\
\text { freedom, transparency, economic growth } \\
\text { and free and fair elections }{ }_{15} \mathrm{JCS} \\
\text { c. For the past } 16 \text { years, we have steered the } \\
\text { country away from ethnic and regional } \\
\text { politics }{ }_{16} \mathrm{JCS}\end{array}$ & $\begin{array}{l}\text { Material } \\
\text { Material }\end{array}$ \\
\hline 26. & $\begin{array}{l}\text { Rationalising } \\
\text { defeat }\end{array}$ & $\begin{array}{l}\text { a. I have had successes }{ }_{84} \text { CCS } \\
\text { b. and I've had setbacks }{ }_{85} \text { CCS } \\
\text { c. You will have successes and setbacks too }{ }_{88} \\
\text { CCS }\end{array}$ & $\begin{array}{l}\text { Relational } \\
\text { Relational } \\
\text { Relational }\end{array}$ \\
\hline
\end{tabular}

\section{Experiential Meanings in Aspirants' Plea to Continue Fighting}

The significant distribution of material, mental and relational processes within aspirants' plea to supporters to continue fighting purveys their experiential meanings, as found largely in CCS and, only once, in JCS. Through mental processes, Clinton acknowledges the hurtfulness of their election loss, and further seeks to sustain supporters' belief in continuing the fight (for their values and ideals); and she expresses hope in a woman presidency, while inspiring little girls' aspirations. These are represented in Example 27 (see Table 15).

The experiential function of these mental processes is therefore to maintain the supporters' belief in continuing the fight as a mark of buoyancy. This ideation 
carries on in the experiential meaning of relational processes as Examples 28a and $28 \mathrm{~b}$ manifest. In these examples, the speaker wants the supporters to remain upbeat on the heel of their loss and not to be weak because of it; and the intention is to encourage her backers to continue fighting.

The material processes crown the experiential meanings through obligated actions required to weather the storm of election defeat. These actions like the ones in 29a and 29b "and we will go forward together," and "We must stand together..." are a charge to party faithful to keep striving and not allow the experience to divide them; but rather to keep working to entrench their principles in the people and hope to regain power in future elections.

Table 15. Ideational Functions and Transitivity Processes in Concession 3

\begin{tabular}{|c|c|c|c|}
\hline $\mathbf{S} / \mathbf{N}$ & $\begin{array}{l}\text { Ideational } \\
\text { Functions }\end{array}$ & Examples & $\begin{array}{c}\text { Transitivity } \\
\text { processes }\end{array}$ \\
\hline 27. & $\begin{array}{l}\text { Sustaining } \\
\text { the belief to } \\
\text { continue } \\
\text { fighting }\end{array}$ & $\begin{array}{l}\text { a. This loss hurts }{ }_{89} \mathrm{CCS} \\
\text { b. but please never stop believing that } \\
\text { fighting for what's right is worth it } t_{90} \mathrm{CCS}\end{array}$ & $\begin{array}{l}\text { Mental } \\
\text { Mental }\end{array}$ \\
\hline 28. & $\begin{array}{l}\text { Encouraging } \\
\text { backers to } \\
\text { fight on }\end{array}$ & $\begin{array}{l}\text { a. Our best days are still ahead of us }{ }_{106} \text { CCS } \\
\text { b. Let us not grow weary }{ }_{115} \text { CCS }\end{array}$ & $\begin{array}{l}\text { Relational } \\
\text { Relational }\end{array}$ \\
\hline 29. & $\begin{array}{l}\text { Charging to } \\
\text { keep striving }\end{array}$ & $\begin{array}{l}\text { a. and we will go forward together }{ }_{108} \\
\text { b. We must stand together as a party and } \\
\text { look to the future with renewed } \\
\text { optimism }_{20} \text { JCS }\end{array}$ & $\begin{array}{l}\text { Material } \\
\text { Material }\end{array}$ \\
\hline
\end{tabular}

\section{Abstract Actions of Closing Benediction}

Like many political speeches, defeat concession closes with a benediction. It entails the invocation of divine blessing on the people and the country as an active entity. In concession speeches, this is put forward as a prayer for a divine action towards certain referents. It is allotted the least space in the discourse, but the sole use of a transitivity process in enacting it evokes the attention given to it. The common occurrences are:

30. May God bless you 120 (CCS)

31. and may God bless the United States of America 121 (CCS)

32. May God Almighty continue to bless the Federal Republic of Nigeria 24 (JCS)

These are all material processes, enacted as a prayer (in a subjunctive mood) each with the modal may placed before the Actor God, who is implored to perform the material process bless towards the Goal you (in this case, the supporters)-which is the United States of America, or the Federal Republic of Nigeria. Such implored action, especially towards the country, without any projected ill feeling, shows the gracious manner aspirants sign off their concession speech and handle their election loss. 


\section{Findings and Conclusion}

Political aspirants, by their concession speech, encode their election loss to reflect its divergent realities within the chosen themes that define the generic structure of the speech. This is symbolised in this study through the experiential functions of their language, as represented through the transitivity framework. The study identifies the nine themes constituting the generic structure of political concession to be Appreciation, Concession, Good Wishes, Recalling Defeat, Closing Ranks, Inclining to Democracy, Framing, A Plea to Fight on, and Benediction. Appreciation takes the largest share of the discourse units, 32.5\%, with only Inclination to Democracy having lesser with $23 \%$. On the contrary, the actual Concession in the speech falls among the themes with the least discursive density, with a distribution of 2.9\%; a finding which illustrates that defeated aspirants devote very intangible discursive space to the act of concession, and rather exploit the medium to thank their supporters, family, party colleagues and the electorate; and to change the post-election narrative, as a first momentous occasion for rebuilding their public image.

Four transitivity processes feature most prominently in the data, and they are material (with $32.1 \%$ distribution), relational, especially, attributive (24.8\%), mental $(21.1 \%)$ and verbal $(17.7 \%)$ processes. These are spread across the themes to encrypt varying defeat realities by their distinctive use. Under Appreciation, the aspirants' gratitude is mostly verbalised (verbal processes: $38.2 \%$ ), echoing the actions/events (material processes: $21.1 \%$ ) motivating the thankful gesture, and indexing the appreciative attributes (relational processes: $21.1 \%$ ) that prop the thematic act. In regard to the infinitesimal but core Concession act, verbal, material and relational processes are evenly eked out to respectively prelude the concession (by "making the call"), enact the speech act (of concession), and coat it with maturity and grace. Notably, the actual act of concession is a verbalisation in a clause.

In the themes of Recalling Defeat and Closing Ranks, which only appear in $\mathrm{CCS}$, we are availed, through the mental processes, of the inner experiences of the losing camp, like the feeling of disappointment, and their cognitive response towards it; as informed (through the relational processes) by their yielding identification of the opponent as the winner, and ascribed allegiance to him; which necessitate the outer efforts taken to succumb to the election defeat (as construed through material processes). As a face-saving measure (to justify their condescension) and image re-building strategy, aspirants switch to Inclination of Democracy to change their identity from a loser to a democrat as they (through the mental and relational processes) incline their supporters towards democratic ideals by entrenching the cognitive basis, attributes and identifying properties for them to continue advancing these core values; and further (through the material processes) mobilise them (their supporters) towards democratic actions, in deference to the constitution.

With Framing, material processes are abundantly engaged to deflect attention to more positive political events, like past party achievements; and relational processes are used to rationalise the loss as just one of life's setbacks, in order to 
diminish its import psychologically, and easily get by the defeat. A Plea to Fight on follows with balanced use of mental (mostly, cognitive) and relational (all attributive) processes to imbue resilience in the apologists; and this is complemented by material processes, which construe obligated actions arising from optimism for future success. The concession genre ends with Benediction, comprising implored divine actions (only material processes) of blessings towards followers and the country, thus manifesting the gracious manner aspirants sign off their concession speech.

In conclusion, the ideational reading of election defeat speech has revealed that it transcends bringing a closure to an election, and includes resetting postelection narrative away from defeat, transforming identity from a loser to a democrat and achiever, renewing tarnished image, and keeping the fold together, all as political postures for future elections. This is why it is recommended that politicians should not see an election loss as an end to their political career, and so their post-election discursive engagement should chart a course forward.

\section{Bibliography}

Adedara, A. A. (2018). If indeed this is the will of the ekiti people: A discursive critique of a concession speech. Journal of Language and Politics, 17(4), 461-484.

Ademilokun, M. (2016). Appraisal of resources in post-election defeat concession speeches of some gubernatorial candidates in southwestern Nigeria, 2014-2015. Africology: The Journal of Pan African Studies, 9(1), 167-187.

Arnurudu, S. M., Oduola, T. A. (2017). A critical discourse analysis of concession speeches: Goodluck Jonathan, Kayode Fayemi and Mitt Romney. Journal of Humanities and Social Science, 22(3), 15-26.

Bradac, J. J. (1999). Language and social interaction: Nature abhors uniformity. Research on Language and Social Interaction, 32, 11-20.

Corcoran, P. (1994). Presidential concession speeches: The rhetoric of defeat. Political Communication, 11, 109-131.

Corcoran, P. (1998). The rhetoric of triumph and defeat: Australian federal elections, 1940-1993. Australian Journal of Communication, 25(1), 69-86.

Halliday, M. A. K. (1985). An introduction to functional grammar. Arnold.

Halliday, M. A. K. (1994). An introduction to functional grammar (2nd Ed.). Arnold.

Halliday, M. A. K., Matthiessen, C. M. (2004). An introduction to functional grammar. Routledge.

Kleinknecht, S., Shaffir, W. (n.d.). The trauma of political defeat. Ontario Association of Former Parliamentarians. Retrieved https://bit.ly/2vsFNNi.

Koussouhon, L. A., Dadjo, S. D. Y. (2016). Pragmatic analyses of president Goodluck Jonathan's concession speech and general Muhammadu Buhari's acceptance speech: A comparative appraisal. International Journal of Applied Linguistics \& English Literature, 5(4), 12-19.

Lakoff, R. T. (2001). The rhetoric of the extraordinary moment: The concession and acceptance speeches of $\mathrm{Al}$ Gore and George W. Bush in the 2000 presidential election". Pragmatics, 11(3), 309-327.

Mirer, M. L., Bode, L. (2015). Tweeting in defeat: How candidates concede and claim victory in 140 characters. New Media and Society, 17(3), 453-469. 
Okoye, A. N., Mmadike, B. I. (2016). A study of concession speech by president Goodluck Jonathan. Unizik Journal of Arts and Humanities, 17(1), 156-166.

Opeibi, T. (2007). One message, many tongues: An exploration of media multilingualism in Nigerian political discourse. Journal of Language and Politics, 6(2), 223-248.

Osisanwo, W. (2008). An introduction to discourse analysis and pragmatics. FemolusFetop Publishers.

Osisanwo, A. A. (2011). Language and ideology in News Magazine's Representation of Nigeria's 2003 and 2007 general elections [Unpublished doctoral dissertation]. Department of English, University of Ibadan.

Osisanwo, A. A. (2012). Conversationalisation of discourse in Tell and The News' representation of Nigerian general elections (NGE). Working Papers: Journal of English Studies, 5(1), 166-185.

Osisanwo, A. A. (2013). Discourse representation in news stories on Obasanjo's third term plot in TELL and THE NEWS. Ibadan Journal of Humanistic Studies, 23(1), 115141.

Osisanwo, A. A. (2016a). Role allocation in the media representation of participants in selected electoral discourses in Nigeria. Athens Journal of Mass Media and Communications, 2(3), 183-204.

Osisanwo, A. A. (2016b). Vote for us, not for them: Discursive strategies and ideological structures in the 2015 campaign SMS messages for the next faculty head. Ibadan Journal of Humanistic Studies, 26(1), 135-157.

Osisanwo, A. A. (2016c). Representation of Nigerian general elections and social actors in selected Nigeria news magazines' reports. In A. Odebunmi, A. Osisanwo, H. Bodunde, S. Ekpe (Eds.), Grammar, applied linguistics and society: A festschrift for Wale Osisanwo (pp. 248-265). Obafemi Awolowo University Press.

Osisanwo, A. A. (2017). I belong to everybody yet to nobody: pragmatic acts in President Muhammadu Buhari's inaugural speech. Athens Journal of Mass Media and Communications. Vol. 3(4). 297-320.

Osisanwo, A. A., Chinaguh, E. (2018). Rhetorical relations in presidential concession speeches of Goodluck Jonathan of Nigeria and John Mahama of Ghana. In A. Osisanwo, I. Olaosun, and I. Odebode (Eds.), Discourse stylistics, sociolinguistics and society: A festschrift for Ayo Ogunsiji. Stirling-Horden.

Oyeleye, L., Osisanwo, A. A. (2013a). Expression of 1deologies in the media representation of the 2003 and 2007 general elections in Nigeria. Discourse \& Society, 24(6), 763-773.

Oyeleye, L., Osisanwo, A. A. (2013b). Lexicalisation in media representation of the 2003 and 2007 general elections in Nigeria. World Journal of English Language, 3(2): 1-9.

Weaver, R. A. (1982). Acknowledgment of victory and defeat: The reciprocal ritual. Central States Speech Journal, 33(3), 480-489. 